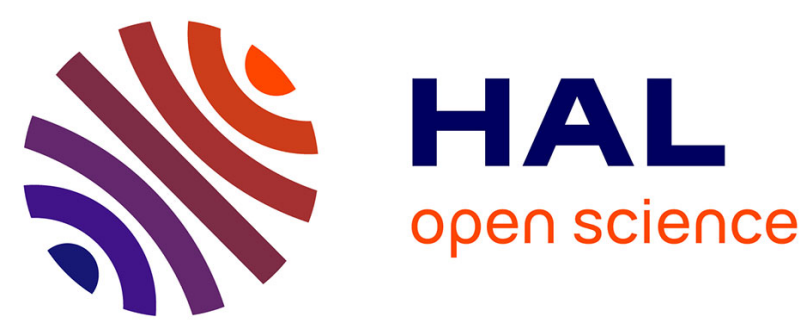

\title{
The marine vegetation of the Kerguelen Islands: history of scientific campaigns, inventory of the flora and first analysis of its biogeographical affinities
}

Jean-Pierre Féral, Marc Verlaque, Sebastián Rosenfeld, Elie Poulin, Anne Chenuil, Thomas Saucède

\section{To cite this version:}

Jean-Pierre Féral, Marc Verlaque, Sebastián Rosenfeld, Elie Poulin, Anne Chenuil, et al.. The marine vegetation of the Kerguelen Islands: history of scientific campaigns, inventory of the flora and first analysis of its biogeographical affinities. Cryptogamie, Algologie, 2021, 42 (12), pp.173-216. 10.5252/cryptogamie-algologie2021v42a12 . hal-03331534

\author{
HAL Id: hal-03331534 \\ https://hal.science/hal-03331534
}

Submitted on 2 Sep 2021

HAL is a multi-disciplinary open access archive for the deposit and dissemination of scientific research documents, whether they are published or not. The documents may come from teaching and research institutions in France or abroad, or from public or private research centers.
L'archive ouverte pluridisciplinaire HAL, est destinée au dépôt et à la diffusion de documents scientifiques de niveau recherche, publiés ou non, émanant des établissements d'enseignement et de recherche français ou étrangers, des laboratoires publics ou privés. 


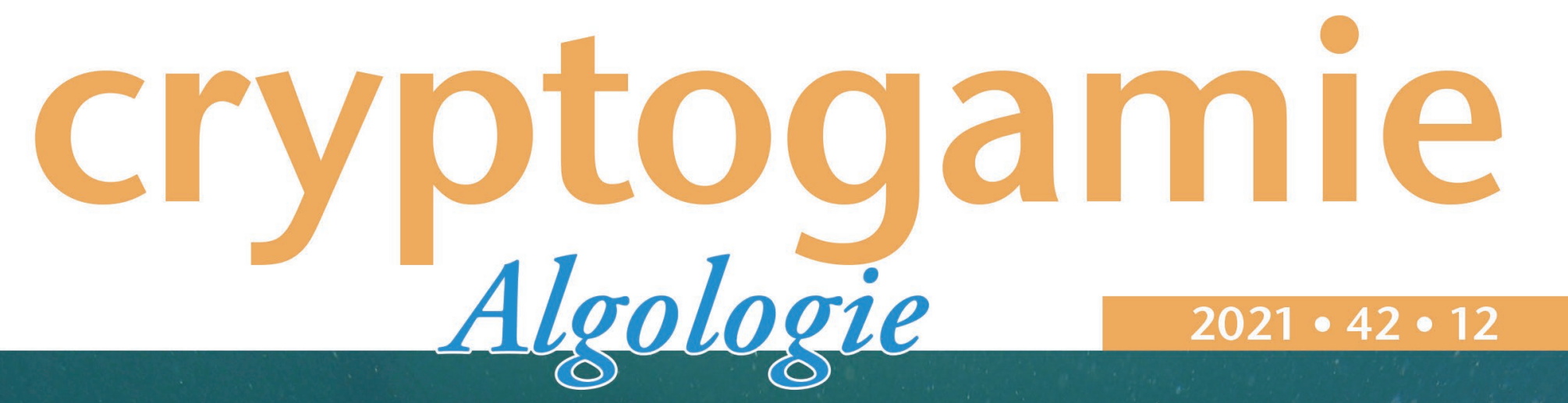

The marine vegetation of the Kerguelen Islands: history of scientific campaigns, inventory of the flora and first analysis of its biogeographical affinities

Jean-Pierre FÉRAL, Marc VERLAQUE, Sebastián ROSENFELD, Elie POULIN, Anne CHENÜL \& Thomas SAUCĖDE

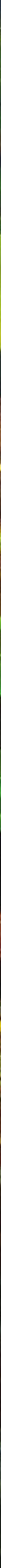


DiRECTEUR de LA PUblication / Publication DiRECTOR: Bruno DAVID

Président du Muséum national d'Histoire naturelle

RÉDACTRICE EN CHEF / EDITOR-IN-CHIEF : Line LE GALL

Muséum national d'Histoire naturelle

ASSISTANTE DE RÉDACTION / AsSISTANT EDITOR : Marianne SALAÜN (algo@cryptogamie.com)

MISE EN PAGE / PAGE LAYOUt : Marianne SALAÜN

RÉDACTEURS ASSOCIÉS / AsSOCIATE EDITORS

Ecoevolutionary dynamics of algae in a changing world

Stacy KRUEGER-HADFIELD

Department of Biology, University of Alabama, 1300 University Blvd, Birmingham, AL 35294 (United States)

Jana KULICHOVA

Department of Botany, Charles University, Prague (Czech Republic)

Cecilia TOTTI

Dipartimento di Scienze della Vita e dell'Ambiente, Università Politecnica delle Marche, Via Brecce Bianche, 60131 Ancona (Italy)

Phylogenetic systematics, species delimitation \& genetics of speciation

Sylvain FAUGERON

UMI3614 Evolutionary Biology and Ecology of Algae, Departamento de Ecología, Facultad de Ciencias Biologicas,

Pontificia Universidad Catolica de Chile, Av. Bernardo O’Higgins 340, Santiago (Chile)

Marie-Laure GUILLEMIN

Instituto de Ciencias Ambientales y Evolutivas, Universidad Austral de Chile, Valdivia (Chile)

Diana SARNO

Department of Integrative Marine Ecology, Stazione Zoologica Anton Dohrn, Villa Comunale, 80121 Napoli (Italy)

Comparative evolutionary genomics of algae

Nicolas BLOUIN

Department of Molecular Biology, University of Wyoming, Dept. 3944, 1000 E University Ave, Laramie, WY 82071 (United States)

Heroen VERBRUGGEN

School of BioSciences, University of Melbourne, Victoria, 3010 (Australia)

Algal physiology \& photosynthesis

Janet KÜBLER

California State University Northridge, Department of Biology, California State University, Northridge, CA 91330-8303 (United States)

Prokaryotic algae

Nico SALMASO

IASMA Research and Innovation Centre, Fondazione Mach-Istituto Agrario di S. Michele all'Adige, Limnology and River Ecology,

Via E. Mach, 1, 38010 San Michele all'Adige, Trento (Italy)

Vitor VASCONCELOS

Faculdade de Ciências da Universidade do Porto and CIIMAR, Rua do Campo Alegre, s/n, 4169-007 Porto (Portugal)

COUVERTURE / COVER:

Communauté algale observée en plongée par une dizaine de mètres de profondeur, près de la base de Port-aux-Français, dans la Baie du Morbihan pendant l'été austral, photo Proteker. / Algal community observed by diving at a depth of about ten meters, in the vicinity of the base of Port-aux-Français, in the Baie du Morbihan during the austral summer, photo Proteker.

Cryptogamie, Algologie est indexé dans / Cryptogamie, Algologie is indexed in:

- Aquatic Sciences \& Fisheries Abstracts Part I.

- Biological Abstracts

- Chemical Abstracts

- Current Contents

- Marine Science Contents Tables (FAO)

- Science Citation Index

- Publications bibliographiques du CNRS (Pascal).

Cryptogamie, Algologie est distribué en version électronique par / Cryptogamie, Algologie is distributed electronically by:

- BioOne ${ }^{\circledR}$ (http://www.bioone.org/loi/crya)

Cryptogamie, Algologie est une revue en flux continu publiée par les Publications scientifiques du Muséum, Paris Cryptogamie, Algologie is a fast track journal published by the Museum Science Press, Paris

Les Publications scientifiques du Muséum publient aussi / The Museum Science Press also publishes: Adansonia, Geodiversitas, Zoosystema, Anthropozoologica, European Journal of Taxonomy, Naturae, Comptes Rendus Palévol, Cryptogamie sous-sections Bryologie, Mycologie.

Diffusion - Publications scientifiques Muséum national d'Histoire naturelle

CP 41 - 57 rue Cuvier F-75231 Paris cedex 05 (France)

Tél. : 33 (0)1 40794805 / Fax: 33 (0)1 40793840

diff.pub@mnhn.fr / http://sciencepress.mnhn.fr

(c) Publications scientifiques du Muséum national d'Histoire naturelle, Paris, 2021

ISSN (imprimé / print): 0181-1568 / ISSN (électronique / electronic): 1776-0984 


\title{
The marine vegetation of the Kerguelen Islands: history of scientific campaigns, inventory of the flora and first analysis of its biogeographical affinities
}

\author{
Jean-Pierre FÉRAL \\ Aix Marseille Université / CNRS / IRD / Avignon Université, UMR7263-IMBE, \\ Institut Méditerranéen de Biodiversité et d'Écologie marine et continentale, \\ Station Marine d'Endoume, Marseille (France) \\ jean-pierre.feral@imbe.fr (corresponding author)
}

Marc VERLAQUE Aix Marseille Université / CNRS / IRD / Université de Toulon, UMR 7294-MIO, Institut Méditerranéen d'Océanologie \& GIS Posidonie, Campus de Luminy, Marseille (France)

Sebastián ROSENFELD

Universidad de Magallanes, Laboratorio de Ecosistemas Marinos Antárticos y Subantárticos, Punta Arenas and Universidad de Chile, Laboratorio de Ecología Molecular, Departamento de Ciencias Ecológicas, Facultad de Ciencia, Santiago and Instituto de Ecología y Biodiversidad (IEB), Santiago (Chile)

Elie POULIN

Universidad de Chile, Laboratorio de Ecología Molecular, Departamento de Ciencias Ecológicas, Facultad de Ciencia, Santiago and Instituto de Ecología y Biodiversidad (IEB), Santiago (Chile)

Anne CHENUIL

Aix Marseille Université / CNRS / IRD / Avignon Université, UMR7263-IMBE, Institut Méditerranéen de Biodiversité et d'Écologie marine et continentale, Station Marine d'Endoume, Marseille (France)

Thomas SAUCÈDE

Biogéosciences, UMR 6282, CNRS, Université Bourgogne Franche-Comté, Dijon (France)

Submitted on 13 November 2020 | Accepted on 6 May 2021 | Published on 1 September 2021

Féral J.-P., Verlaque M., Rosenfeld S., Poulin E., Chenuil A. \& Saucède T. 2021. - The marine vegetation of the Kerguelen Islands: history of scientific campaigns, inventory of the flora and first analysis of its biogeographical affinities. Cryptogamie, Algologie 42 (12): 173-216. https://doi.org/10.5252/cryptogamie-algologie2021v42a12. http:// cryptogamie.com/algologie/42/12

\section{ABSTRACT}

Conceived as a baseline for the management and conservation of the marine protected area of the French Southern Territories (réserve naturelle nationale des Terres australes françaises), the checklist of marine macroalgae of the Kerguelen Islands was updated based on an extensive review of the literature and scientific databases, from the first report of the Ross expedition, in 1840, to the most 
KEY WORDS

Checklist,

macroalgae,

Rhodophyta,

Chlorophyta

Ochrophyta -Phaeophyceae,

Southern Ocean,

coastal benthos,

global change,

natural reserve,

French Southern, proteker,

scientific diving.

MOTS CLÉS

Inventaire,

macroalgues,

Rhodophyta,

Chlorophyta

Ochrophyta-Phaeophyceae,

Océan Austral,

benthos côtier,

changement global,

réserve naturelle,

Terres australes françaises,

proteker,

plongée scientifique. recent works. This work was also conceived as a starting point for forthcoming investigations using molecular systematics tools and for monitoring the effects of global change on sub-Antarctic marine ecosystems. After a brief history of scientific campaigns, a list of 166 species was established (103 Rhodophyta, 35 Chlorophyta and 28 Ochrophyta [Phaeophyceae]). Molecular systematics studiess have shown the existence of recurrent discrepancies between the established, morphology-based taxonomy and molecular species delimitation, calling for a revision of systematics. Nevertheless, a first analysis of biogeographical affinities of the marine flora of the Kerguelen Islands is carried out and preliminary results are partially congruent with the main regions currently recognized in the Southern Ocean suggesting the importance of long-distance dispersal to explain the observed distribution patterns.

\section{RÉSUMÉ}

La végétation marine des îles Kerguelen, inventaire de la flore et première analyse de ses affinités biogéographiques.

Conçu comme une base de référence indispensable à la gestion et à la conservation de la flore marine dans l'aire marine protégée des Terres australes françaises (réserve naturelle nationale des Terres australes françaises), l'inventaire de la flore marine des îles Kerguelen a été mis à jour sur la base d'un examen approfondi de la littérature et des bases de données scientifiques, du premier rapport de l'expédition Ross, en 1840, jusqu'aux travaux les plus récents. Ce travail a aussi pour objectif de constituer un point de départ pour de futures investigations utilisant les outils de la systématique moléculaire, et pour le suivi des effets du changement global sur les écosystèmes marins subantarctiques. Après un bref historique des campagnes scientifiques menées, une liste de 166 espèces a été établie (103 Rhodophyta, 35 Chlorophyta et 28 Ochrophyta [Phaeophyceae]). Les travaux récents ont montré l'existence de divergences récurrentes entre la taxinomie actuelle, établie sur des caractères morphologiques et la délimitation moléculaire des espèces, préconisant une révision de la systématique des macroalgues. Une première analyse des affinités biogéographiques de la flore marine des îles Kerguelen a été cependant réalisée et les résultats préliminaires se sont révélés en partie congruents avec les grandes régions actuellement reconnues dans l'océan Austral, suggérant l'importance du phénomène de dispersion sur de longues distances pour expliquer les motifs de distribution observés.

\section{INTRODUCTION}

The Kerguelen Islands (49 $20^{\prime}$ S, 69 $20^{\circ} \mathrm{E}$ ) are in the Southern Ocean (hereafter SO), $3900 \mathrm{~km}$ southeast of South Africa, $1950 \mathrm{~km}$ north of Antarctica and $4000 \mathrm{~km}$ west of Australia (Fig. 1). They were officially discovered by the French navigator Yves-Joseph de Kerguelen-Trémarec on February $12^{\text {th }}, 1772$, aboard the fluyt (Dutch sailing cargo vessel) La Fortune and the maritime gabare (sailing scow) Le Gros Ventre. First scientific investigations however began with Captain James Cook's exploration four years later. Cook reached the Kerguelen Islands on December 25th, 1776 on his third circumnavigation onboard the HMS Resolution and HMS Discovery. Soon after being discovered, the islands were regularly visited by whalers and seal hunters (mainly British, American, and Norwegian) during the 19th century. The Kerguelen Islands $\left(7215 \mathrm{~km}^{2}\right)$ consist of a main island, the so-called Grande Terre, surrounded by around 300 smaller islands and islets (Fig. 2). They emerge in the flow of the Antarctic Circumpolar Current (hereafter ACC), in the vicinity of the Antarctic Convergence where distinct water masses meet (Antarctic Surface Waters, Polar Front Surface Waters and sub-Antarctic Surface Waters). The Kerguelen Plateau also emerges $450 \mathrm{~km}$ southeast of the Kerguelen Islands at Heard and McDonald Islands.
Since the discovery of the islands, marine coastal habitats have been little impacted by direct anthropogenic disturbance (Lecomte et al. 2013). They are still pristine marine ecosystems that constitute effective sentinels to assess the effects of global change. The proximity of the sub-Antarctic and Polar fronts put the marine biota of the Kerguelen Islands particularly at risk, exposing them to the effects of climate change. The distinct water masses are predicted to shift southwards in the future, resulting in drastic environmental changes and affecting coastal marine species and ecosystem functioning (Park et al. 2014; Féral et al. 2016a, b, 2019). Significant impacts can be expected on local benthic communities in which many species have limited resilience ability (Stenni et al. 2017; Gutt et al. 2018; Guillaumot et al. 2018; Saucède et al. 2019). To mitigate the impacts of environmental changes and protect marine living resources, the Kerguelen Islands were made part of the National Nature Reserve of the French Southern Territories (réserve naturelle nationale des Terres australes françaises: RNN-TAF) (decree $n^{\circ} 2016-1700$ of December 12 th 2016), and marine coastal areas have been placed on the status of enhanced protection (Ia IUCN category) (Day et al. 2012).

Interpreting ecological changes in marine life and implementing appropriate management plans require setting up long-term and cross-disciplinary field observing systems of 


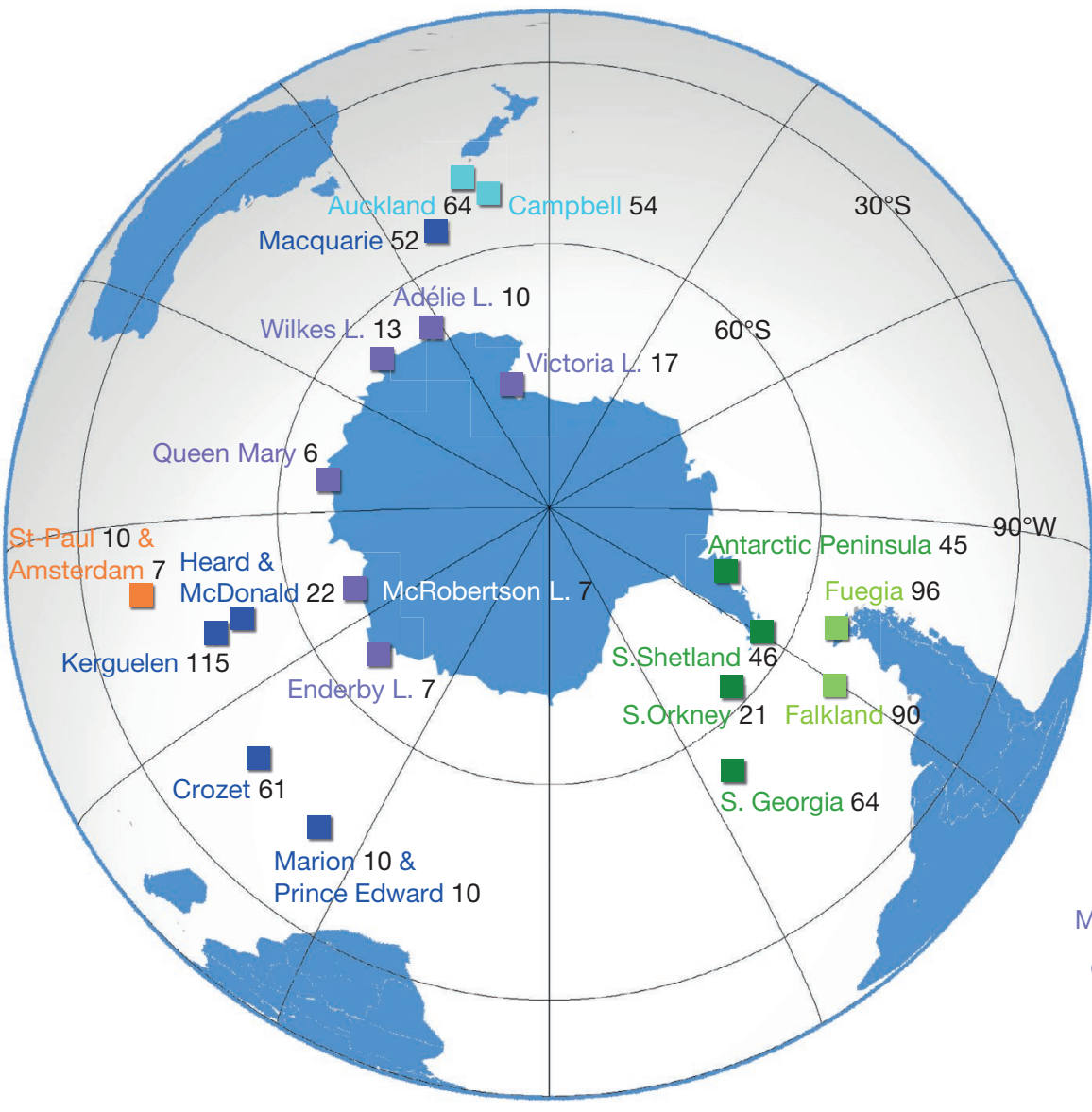

\begin{tabular}{rrr} 
Sites & latitude & longitude \\
Amsterdam I & -37.83318 & 77.55033 \\
St-Paul I & -38.73247 & 77.52613 \\
Marion I & -46.89411 & 37.73776 \\
Pr. Edward Is & -46.64029 & 37.93844 \\
Crozet Is & -46.41503 & 51.77721 \\
Kerguelen Is & -49.38920 & 69.35608 \\
Heard I & -53.09481 & 73.50061 \\
Macquarie I & -54.61816 & 158.85378 \\
Auckland Is & -50.76234 & 166.05981 \\
Campbell Is & -52.51735 & 169.15435 \\
Fuegia & -53.99479 & -68.52800 \\
Falkland Is & -51.68386 & -59.33418 \\
S.Georgia I & -54.40299 & -36.58705 \\
\hline S.Shetland Is & -62.14226 & -58.46222 \\
S.Orkney Is & -60.62587 & -45.39038 \\
Antarctic Pen. & -66.88576 & -66.04036 \\
Enderby L. & -67.53328 & 47.73396 \\
McRobertson L. & -68.80161 & 70.10980 \\
Queen Mary L. & -66.75000 & 96.00000 \\
Wilkes L. & -66.76100 & 140.61090 \\
Adélie L. & -66.66667 & 140.00000 \\
Victoria L. & -76.88737 & 163.56907 \\
\hline & & \\
\hline
\end{tabular}

FIG. 1. - Sub-Antarctic and Antarctic regions considered in the biogeographical analysis of the Kerguelen Islands marine macroalgae also occurring elsewhere in the Southern Ocean. Colours: orange, temperate Southern Africa; blue, sub-Antarctic Islands; light blue, sub-Antarctic New Zealand; light green, Magellanic region; green, Scotia Sea; violet, continental High Antarctic (after Spalding et al. 2007). Geographical coordinates are given in the inset.

physical processes and ecosystem changes (Kennicutt et al. 2016; Cárdenas et al. 2018; Gutt et al. 2018; Féral et al. 2019). For this purpose, the French Long Term Ecological Research PROTEKER observatory was implemented to monitor coastal marine habitats of the Kerguelen Islands (Féral et al. 2016a, b, 2019). Objectives are to identify, monitor and predict changes in marine coastal ecosystems as a basis for vulnerability assessments and appropriate management planning.

As a key component of the benthos (habitats, primary producers, ecosystem engineers, dispersal vectors, etc.), marine macroalgae can constitute useful bio-indicators of the health of coastal marine habitats (Féral et al. 2016a, b, 2019). Unfortunately, "our knowledge of the biodiversity of Antarctic macroalgae is still hampered by the limited database available" (Wiencke et al. 2014). Moreover, very few phylogeographical studies in macroalgae have included samples from the Kerguelen Islands to revise species taxonomy and assess the connectivity between populations across habitats and SO regions (Fraser et al. 2009b, 2018). Thus, the taxonomic status and the occurrence of many species of macroalgae (e.g. Lessonia nigrescens) still requires verification.

In the present work, in-depth survey and analysis of the dedicated literature and scientific data bases were conducted to update the checklist of marine macroalgae of the Kerguelen Islands for the use of benthic ecologists, conservation biologists, and nature reserve managers. The updated checklist was subsequently used to carry on a first analysis of floristic affinities between the Kerguelen Islands and the adjacent regions of the SO. This work is primarily aimed at providing a review and starting point for forthcoming integrative phylogeographical and biogeographical studies using new samplings and molecular analyses.

\section{MATERIAL AND METHODS}

\section{ESTABLISHING THE LIST OF THE MARINE MACROALGAE} OF THE KERGUELEN ISLANDS

The updated taxonomic checklist of macroalgae recorded in the Kerguelen Islands was compiled from an in-depth review of the scientific literature and resources of the library of the Station Marine d'Endoume (Aix Marseille Université) and of the Plateforme Macrophytes of the Institut Méditerranéen d'Océanographie (Aix Marseille Université). The following world-wide databases were also consulted: AlgaeBase (Guiry \& Guiry 2021), the Sonnerat Herbarium database (Sonnerat 
Herbarium database 2020), and the Macroalgal Herbarium Portal (Macroalgal Herbarium Portal 2020). Reference specimens were not re-examined here.

Macroalgal species were organized by taxa (phylum, class, order, and family), and listed in alphabetical order. Taxon names follow the currently accepted taxonomy according to the World Register of Marine Species (WoRMS Editorial Board 2021) and AlgaeBase (Guiry \& Guiry 2021). Original names with known sampling sites are also provided. Occurrence records and sampling sites of the most significant scientific expeditions and works can also be found in the Appendices.

\section{Distribution of KERGUELEN MARINE MACROALGAE} IN OTHER SUB-ANTARCTIC AND ANTARCTIC REGIONS.

The distribution of marine macroalgae recorded in coastal waters of the Kerguelen Islands was reviewed and is reported for 21 Sub-Antarctic and Antarctic regions (Fig. 1). The taxa described from the Northern Hemisphere, cosmopolitan species and those with questionable status or identification were not considered.

Data were issued from (Hooker 1844; Harvey 1849; Kützing 1849, 1855, 1856, 1858, 1859, 1861, 1865, 1866 , 1869; Dickie 1876a, b, c, d, e, f, 1877, 1879; Hariot 1889; Reinsch 1890; Foslie 1899, 1905, 1908; Barton 1902; Gepp \& Gepp 1905a, b, 1907, 1912, 1917; Skottsberg 1907, 1923, 1941, 1953; Gain 1912; Lemoine 1913; Kyling \& Skottsberg 1919; Levring 1944, 1945; Papenfuss 1964a, b; Zaneveld 1964, 1966a, b, 1968, 1988; Delépine et al. 1966; Zinova 1966; Arnaud 1974; Lamb et al. 1975; Moe \& DeLaca 1976; Moe \& Silva 1977, 1979, 1980, 1983; Prescott 1979; South 1979; Zaneveld \& Sanford 1980; Zielinski 1981, 1990; Furmanczyk \& Zielinski 1982; Hay et al. 1985; Hay 1986; Ricker 1987; Lawson 1988; Cinelli et al. 1989; Conde \& Gallardo 1991; Cormaci et al. 1992, 2000; Adams 1994; Chung et al. 1994, 2000; John et al. 1994a, b; Wiencke 1996; Klöser et al. 1996; Clayton et al. 1997; Mendoza 1999; Gallardo et al. 1999; Kim et al. 2001a, b; Quartino et al. 2001; Wiencke \& Clayton 2002; Alongi et al. 2002; Hommersand 2007; Asensi \& Reviers 2009; Hommersand et al. 2009; Broom et al. 2010; Nelson \& Broom 2010; Macaya \& Zuccarello 2010a; Ramírez 2010; Wells et al. 2011; Wiencke \& Amsler 2012; Boraso de Zaixso 2013; Wynne 2013; Mystikou et al. 2014, 2016; Nelson et al. 2014; Wiencke et al. 2014; Lindstrom et al. 2015; Pellizzari et al. 2017; Díaz-Tapia et al. 2020; Guiry \& Guiry 2021; Hughey et al. 2020; Oliveira et al. 2020, except for species reported from "Antarctica" without precise localities).

\section{MACROALGAL SIMILARITY BETWEEN REGIONS}

The analysis is based on data from the literature, some of which are old and only reported as a simple name in a checklist, with no diagnosis for species identification nor discussion of the taxonomic status. Without direct examination of specimens, it was impossible to assess the quality of identifications. The species described in the Northern Hemisphere were a priori rejected because of a high risk of misidentification. For example, Hommersand et al. (2009) noted that unpublished rbcL sequence analyses by S. Fredericq show that Plocamium "cartilagineum" from Antarctica is distinct from all other species of Plocamium investigated so far. Amphi-equatorial species exist but they seem to be rare, and belong to taxonomic groups with a wide distribution (e.g. very tolerant Chlorophyta of upper coastal levels like Prasiola, Rosenvingiella, Ulva and Urospora; Dubrasquet et al. 2021) and therefore may be poorly indicative for a regional biogeographical analysis. Consequently, only a subsample of 115 "southern" species was processed.

The known distribution of Kerguelen macroalgae in the $\mathrm{SO}$ was explored through a network analysis of occurrence data using the software Gephi v.0.9.2 (Bastian et al. 2009). In the network display, regions and species correspond to the nodes $(\mathrm{n}=135)$ and links between species and regions are shown by edges $(n=827)$ with no other assumption, species being linked to the studied regions. A force layout (Jacomy et al. 2014) algorithm was used to untangle the network, and facilitate the reading by dispersing groupings and leaving space around the largest nodes, thereby emphasizing complementarities between regions and preventing nodes overlapping. A special feature of the force-directed graph is that each node is placed according to connections with other nodes. The position of each node should not be interpreted on its own, but in relation with other nodes. The algorithm provides an intuitive way to spatialize the network and display a comprehensive "map".

\section{RESULTS}

FORMER SCIENTIFIC RESEARCHES ON MARINE MACROALGAE OF THE KERGUELEN ISLANDS

Following Cook's exploration, the Kerguelen Islands were not scientifically surveyed until the Ross'expedition, a voyage of exploration of the Antarctic undertaken from 1839 to 1843 aboard the two former warships HMS Erebus and HMS Terror, which were converted for the scientific expedition. The expedition made substantial zoological and botanical observations, resulting in one zoological monograph and a series of four detailed botanical monographs by Joseph Dalton Hooker, collectively named Flora Antarctica (Hooker 1844; Hooker \& Harvey 1845; Harvey 1847, 1849). The Part II (Hooker 1844) contains the first data on marine macroalgae collected between 1840, May $7^{\text {th }}$ and 1841 January 20 $0^{\text {th }}$ at Christmas Harbour, the northernmost embayment in Kerguelen (Fig. 2; Appendix 1). Friedrich Traugott Kützing reported and illustrated several marine macroalgae collected in the Kerguelen Islands during this expedition (Kützing 1849, 1855, 1856, 1858, 1859, 1861, 1865, 1866, 1869) (Appendix 2).

A few decades later, the scientific expedition of the HMS Challenger explored the Kerguelen-Heard Plateau under command of Captain G.S. Nares and leadership of Wyville Thomson. During her circumnavigation (1872-1876), she sailed along the coasts of the Kerguelen Islands from 1873, December 7 th to 1874 , January $31^{\text {st }}$. On that occasion, macroalgae were collected by Henry Nottidge Moseley in the vicinity of Christmas Harbour and along the eastern coast as 


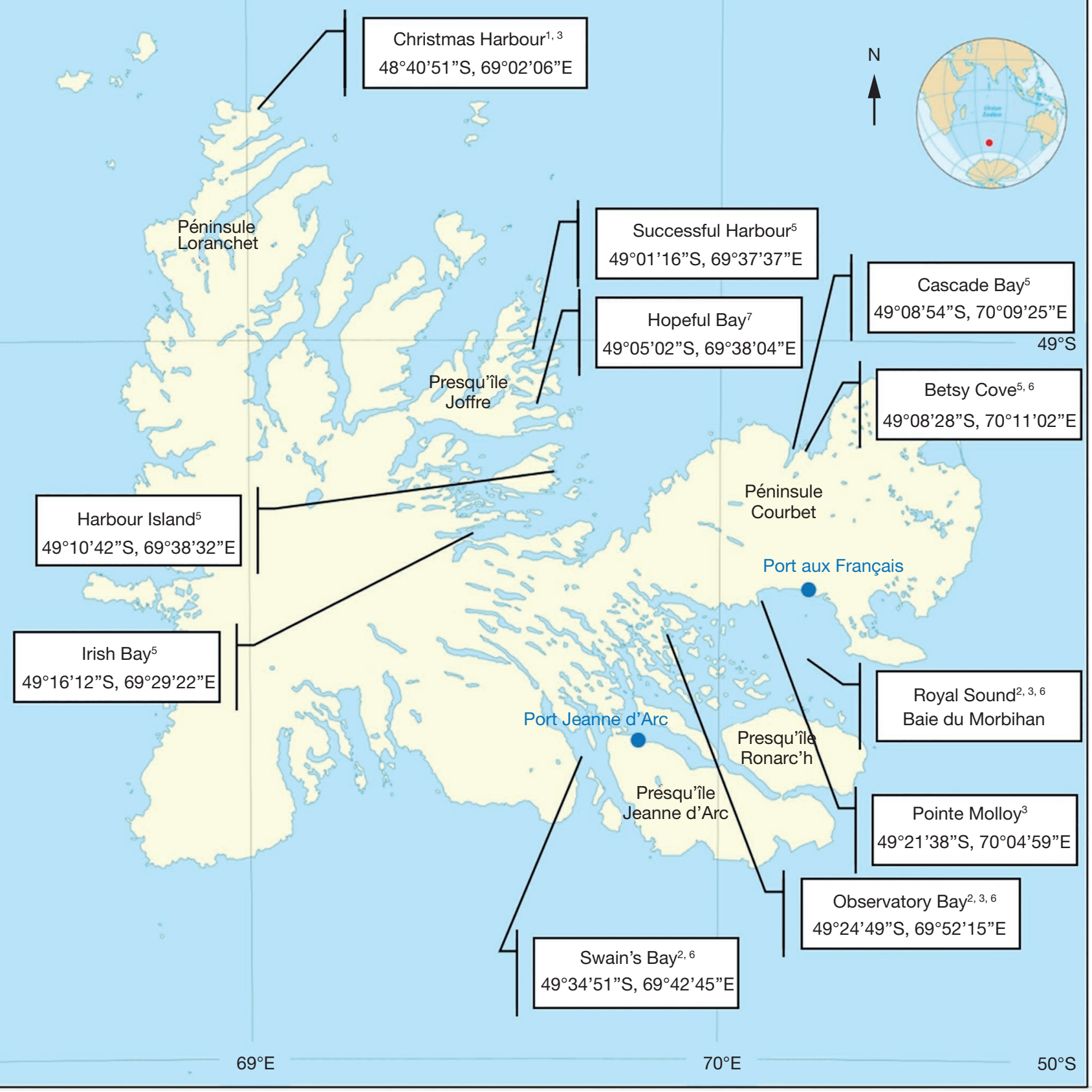

FIG. 2. - Location of historical collections of macroalgae in the Kerguelen Islands. Precise locations are not given by all reports and should be partly inferred. The map shows the sites visited during 1, the Ross expedition (Hooker 1844-1847); ${ }^{2}$, the Challenger expedition (Dickie 1876a, b, c, e); ${ }^{3}$, the US (Farlow 1876); 4, English (Dickie 1876d, f); and 5, German (Askenasy 1889); 6, Venus transit expeditions, as well as the German south polar expedition (Foslie 1908, Reinbold 1908). 7 , The Hopeful Bay (Zinova 1973) was added.

far as Betsy Cove (Fig. 2). Specimens were studied by George Dickie (Dickie 1876a, c, d, f, 1877, 1879) and William Gilson Farlow (Farlow 1876) (Appendices 3; 5).

In 1874-1875, United States, German, and British expeditions visited the Kerguelen Islands to observe the Transit of Venus (1874, December 9th). Scientists took the opportunity to make naturalist observations in the vicinity of land based astronomic observatories. The American expedition, aboard the screw sloop USS Swatara (1873), commanded by Captain Ralph Chandler, was based in the Baie du Morbihan (Pointe Molloy, Baie de l'Observatoire, Fig. 2) from 1874, September $10^{\text {th }}$ to 1875 , January $11^{\text {th }}$. The SMS Gazelle (expedition 1874-1876), a German corvette commanded by Captain Georg Emil Gustav von Schleinitz, was anchored in the 
Anse Betsy (on Baie Accessible, northern coast of Kerguelen) from 1874, October 26th to 1875 , February $6^{\text {th }}$. The English expedition also established in the Baie du Morbihan (Baie de l'Observatoire) in about the same period (1874, November $5^{\text {th }}$ to 1875 , February $27^{\text {th }}$ ). Captain Henry Fairfax, commander of the HMS Volage, made it possible for Alfred Edwin Eaton to explore the Baie des Swains (Fig. 2) on the southern coast of Kerguelen (January 1875) (Appendix 3).

George Dickie made a compilation of the specimens collected by several expeditions and estimated the total number of native marine macroalgae native to 71 (Dickie 1879) (Appendix 4). This estimate was based on collections made by [1] Hooker (Antarctic expedition, May-July 1840, chiefly in Baie de l'Oiseau, 39 species ), [2] Moseley [Challenger expedition, January-February 1874, Baie de l'Oiseau, Anse Betsy (in Baie Accessible), 37 species], and [3] Kidder (U.S. Transit of Venus expedition, September 1874-January 1875 , Pointe Molloy and Baie du Morbihan, 22 species.

Eugen Askenasy published the results of observations made on macroalgae collected during the expedition of the SMS Gazelle (Askenasy 1889) (Appendix 6).

The geologist Erich Dagobert von Drygalski led the first German South Polar expedition aboard the RV Gauss to explore the unknown area of Antarctica lying south of the Kerguelen Islands (1901-1903). A small party of the expedition was stationed in the Baie de l'Observatoire, while the main party proceeded further south. Works on the algae collected in the Kerguelen during the expedition were published by Mikael Foslie (Foslie 1908) and Theodor (Karl August) Reinbold (Reinbold 1908) (Appendix 7).

In his report on the second French Antarctic expedition (1908-1910), Louis Gain compiled a list of 100 species for the Kerguelen marine flora, based on reports of previous expeditions (Gain 1912) (Appendix 8) and reviewed taxonomy changing former taxon names of macroalgae for those in use in his time.

Tore Levring recorded the macroalgae collected during the expedition of the Norwegian sealer SS Solglimt (1907-1908), commanded by Captain Anders Harboe-Ree, in the Crozet and the Kerguelen Islands. He listed 37 species from the Kerguelen Islands (including 14 species previously reported by Dickie 1879). Levring specified that all the sampling information was lost (Levring 1944) (Appendix 9).

In 1958 Anna Dmitrievna Zinova published her work on a collection of macroalgae sampled in the Kerguelen Islands during the $1^{\text {st }}$ Soviet Antarctic Expedition (April 1956, RV Ob commanded by captain I.A. Man) (Zinova 1958), which she completed in 1963 with a publication on the Delesseriaceae (Zinova 1963). A third more specific paper listing the macroalgae collected in the Baie du Hopeful (north coast of Kerguelen, Fig. 2) was published (Zinova 1973) (Appendix 10).

The most recent published synthesis on macroalgae of the Kerguelen Islands was written by George Frederick Papenfuss who reported 138 taxa in his catalogue (Papenfuss 1964a) (Appendix 11).

Following up the establishment of Port-aux-Français Research Station in 1951 and the consecutive chartering of the FV
La Japonaise (1970), RV Marion Dufresne (1970) and RV La Curieuse (1990), coastal waters of the Kerguelen Islands were then thoroughly investigated by regular research programs (Améziane et al. 2011; Féral \& Poulin 2011; Hureau 2011). Marine macroalgae were studied by René Delépine, Aldo Asensi and coworkers among whom Paul Grua who was a pioneer scuba diver (Delépine 1962, 1964, 1966, 1976; Grua 1963, 1964a, b, 1965, 1968, 1971; Delépine \& Grua 1964; Delépine \& Hureau 1966; Delépine et al. 1970, 1979; Delépine \& Asensi 1975). At the same time, Michael Neushul undertook similar studies in Antarctic coastal waters (Neushul 1961, 1965).

In the 1970s, a new impetus was given by R. Delépine who co-authored the macroalgae chapter of the F.A.O. (Food and Agriculture Organization of the United Nations) species identification sheets for the SO and listed 24 species of macroalgae among which 18 have been reported in the Kerguelen Islands as a potential commercial resource (Delépine et al. 1985; Duchêne 1989). In 1996, a more comprehensive list of macroalgae reported from the Kerguelen, Crozet, Saint Paul and Amsterdam Islands (R. Delépine, personal communication to J.-P. Féral) was produced as a contribution to the proposal for the creation of a nature reserve in the French sub-Antarctic islands (Jouventin et al. 1996). This list included 212 taxa, of which 149 were considered to be present in the Kerguelen Islands (Appendix 12).

The commercial potential of macroalgae has been the main focus of research projects carried out in biology, ecology, and chemistry in the Kerguelen Islands since the 1950s, mainly on large Phaeophyceae (e.g. genera Macrocystis and Durvillaea) (Sannié 1951; Delépine 1964, 1976, 1983; Delépine \& Asensi 1978; Asensi et al. 1981; Lambert et al. 1988; Nicod et al. 1988; Belsher \& Mouchot 1992). The taxonomy and biological cycles of the Phaeophyceae Adenocystis utricularis and Utriculidium durvillei and the role of light and temperature in species physiology were also studied by Bruno de Reviers (Reviers de 1980). A few papers also assessed the energetic content of intertidal macroalgae (Lawrence 1986; Lawrence \& McClintock 1987).

\section{THE UPDATED CHECKLIST OF THE MARINE MACROALGAE OF THE KERGUELEN ISLANDS}

A total of 166 taxa of marine macroalgae from the Kerguelen Islands are listed here, compiled from the comprehensive survey of the former scientific literature, and modified following currently accepted taxonomy and classification (Table 1). The Kerguelen Islands are type locality of 35 taxa, among which 25 species (4 Chlorophyta, 3 Phaeophyceae and 18 Rhodophyta) are currently accepted taxon names (Table 2A), six species were synonymized, and four species remain of uncertain taxonomic status (Table 2B).

To date, the Rhodophyta is the most represented phylum with 103 species (62\% of the total species richness), followed by the Chlorophyta (35 species, 21\%) and the Phaeophyceae (28 species, 17\%). The Delesseriaceae (22 species) and Rhodomelaceae (10 species) are the richest families in the Rhodophyta, the Cladophoraceae (11 species) in the 
TABLE 1. - . Amended checklist of Kerguelen Islands' marine macroalgae based on Delépine (personal communication 1996) (R.D.), Zinova 1958,1963,1973 (A.Z.), Papenfuss 1964a (G.P.), Levring 1944 (T.L.), Gain 1912 (L.G.), Reinbold 1908 and Foslie 1908 (R./F.), Askenasy 1889 (E.A.), Dickie 1879 (GD.2), Dickie 1876a-f (GD.1), Farlow 1876 (W.F.), Kützing, 1849, 1855, 1856, 1858, 1859, 1861, 1865, 1866, 1869 (FT.K), Hooker \& Harvey 1845 (H\&H), Hooker 1844 (JD.H). (?), taxa with uncertain taxonomic status or uncertain identification; *, taxa described in the Northern Hemisphere; $\bullet$, taxa reported only from Kerguelen Islands in the Southern Ocean.

JD.H H\&H FT.K W.F. GD.1 GD.2 E.A. R./F. L.G. T.L. G.P A.Z. R.D.

\section{CHLOROPHYTA}

Trebouxiophyceae

Prasiolales

Prasiolaceae

Prasiola crispa subsp. antarctica (Kützing) Knebe Prasiola cristata (J.D.Hooker \& Harvey) J.Agardh Prasiola filiformis Reinsch

\section{Ulvophyceae \\ Bryopsidales \\ Bryopsidaceae \\ Codiaceae}

Cladophorales

Cladophoraceae

Ulotrichales

Monostromataceae Monostroma grevillei (Thuret) Wittrock * Monostroma hariotii Gain

Ulotrichaceae

Acrosiphonia arcta (Dillwyn) Kützing *

Spongomorpha aeruginosa (Linnaeus) Hoek *

Spongomorpha pacifica (Montagne) Kützing

Ulothrix flacca (Dillwyn) Thuret *

Urospora penicilliformis (Roth) Areschoug, including

Codiolum gregarium phase *

Ulvales

Ulvaceae

Ulva compressa Linnaeus *

Ulva hookeriana (Kützing) Hayden, Blomster,

Maggs, Silva, Stanhope \& Waaland

Ulva intestinalis Linnaeus *

Ulva lactuca auct (non Linnaeus) (?)

Ulva lactuca f. latissima auct (non Linnaeus) (?)

Ulva rigida C.Agardh *

Ulvellaceae Ulvella viridis (Reinke) R. Nielsen, C.J.O'Kelly \&

B.Wysor *

OCHROPHYTA

Phaeophyceae

Desmarestiales

Desmarestiaceae

Desmarestia chordalis J.D. Hooker \& Harvey

Desmarestia confervoides (Bory de Saint-Vincent)

M.E.Ramírez \& A.F.Peters

Desmarestia ligulata (Stackhouse) J.V. Lamouroux

(?)

Desmarestia menziesii J.Agardh

Desmarestia rossii J.D.Hooker \& Harvey

Ectocarpales

Desmarestia viridis (O.F.Müller) J.V.Lamouroux *

Acinetosporaceae

Relle Chiaje *

dh

Codium tomentosum Stackhouse *

足

Chaetomorpha litorea Harvey* $*$ Kützing (?)

J.D.Hooker \& Harvey

Cladophora rupestris (Linnaeus) Kützing *

Pseudorhizoclonium africanum (Kützing) Boedeker

Boedeker et al. (?)

riparium (Roth) Harvey*
Geminocarpus geminatus J.D.Hooker \& Harvey)

Skottsberg

Pylaiella littoralis (Linnaeus) Kjellman * 


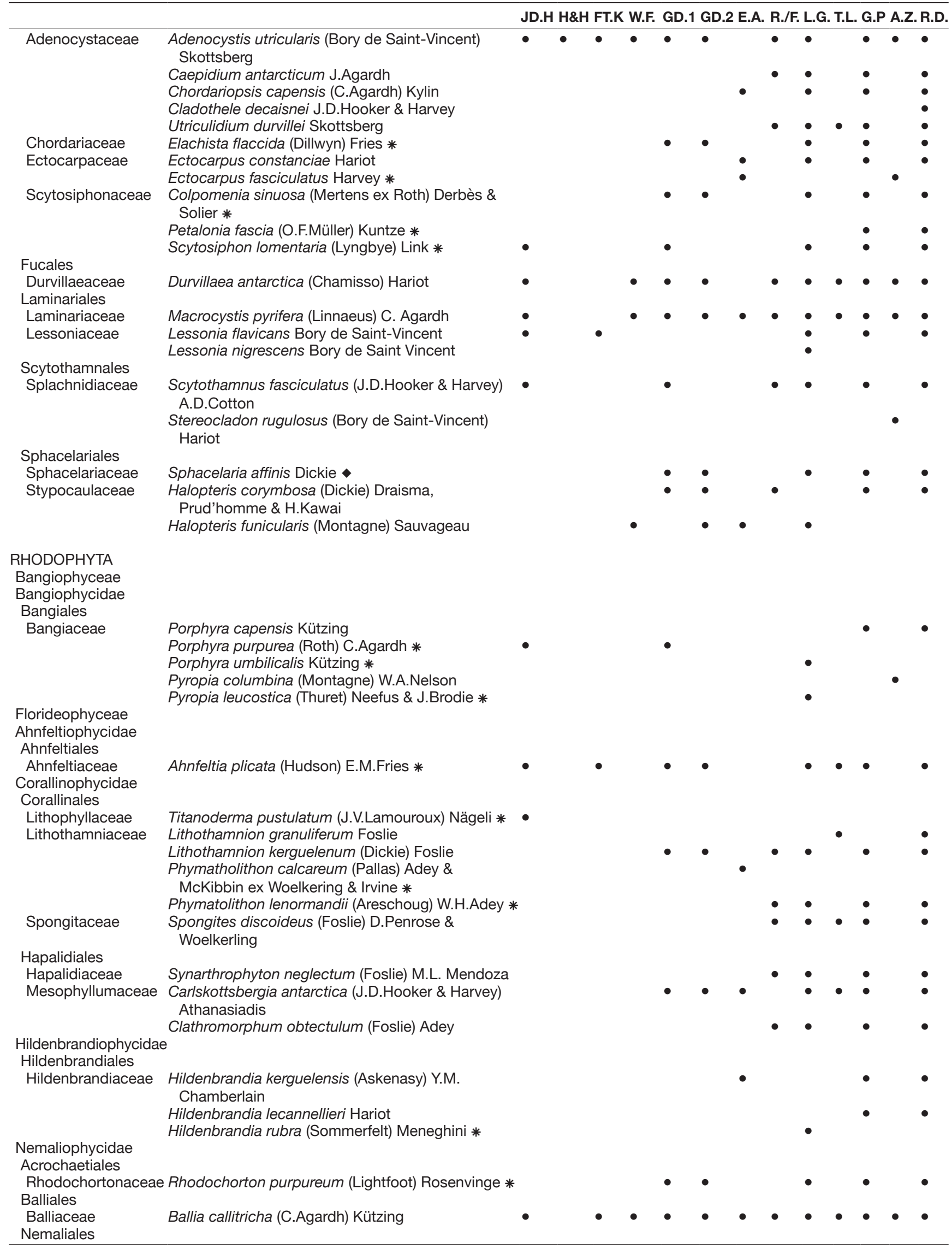




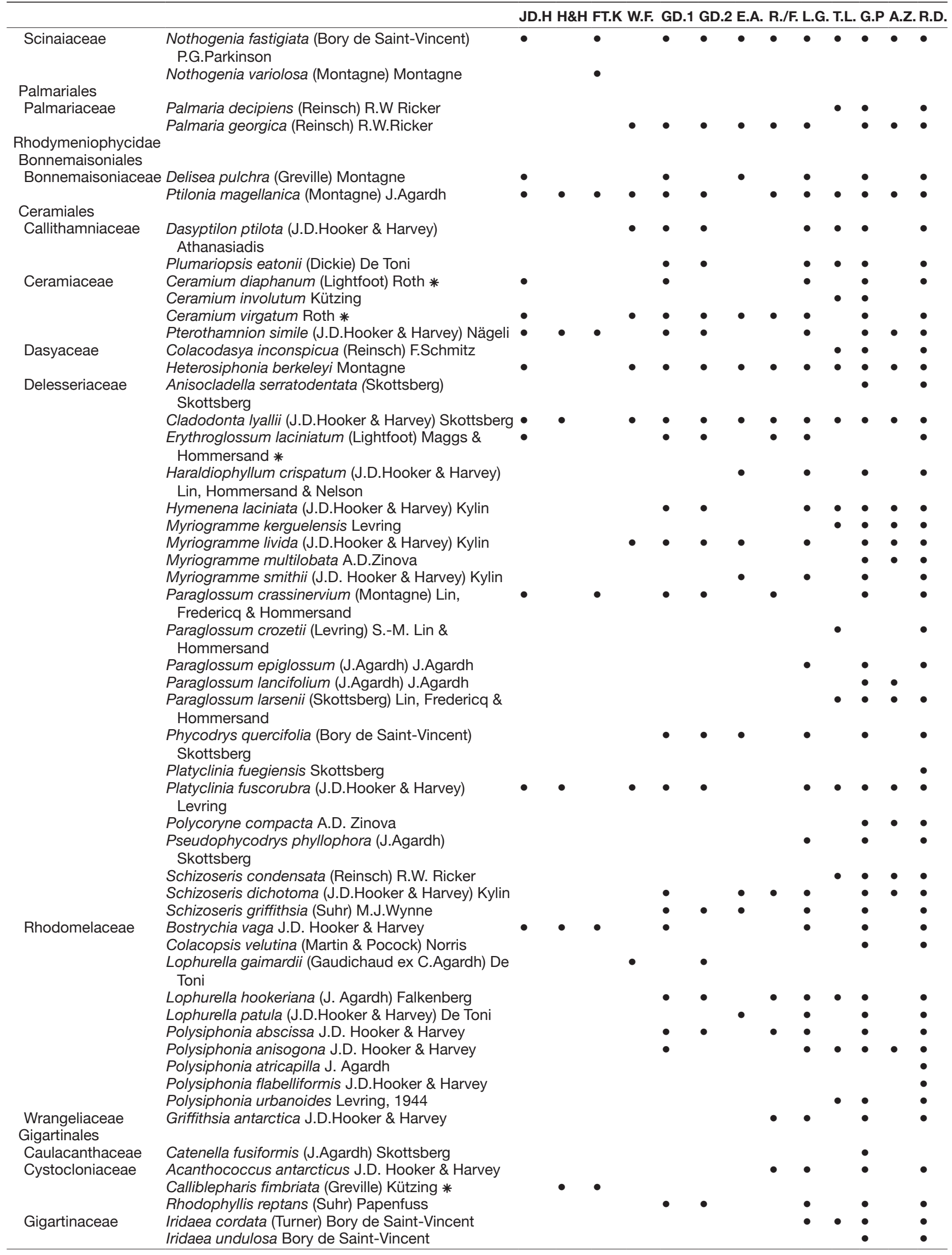




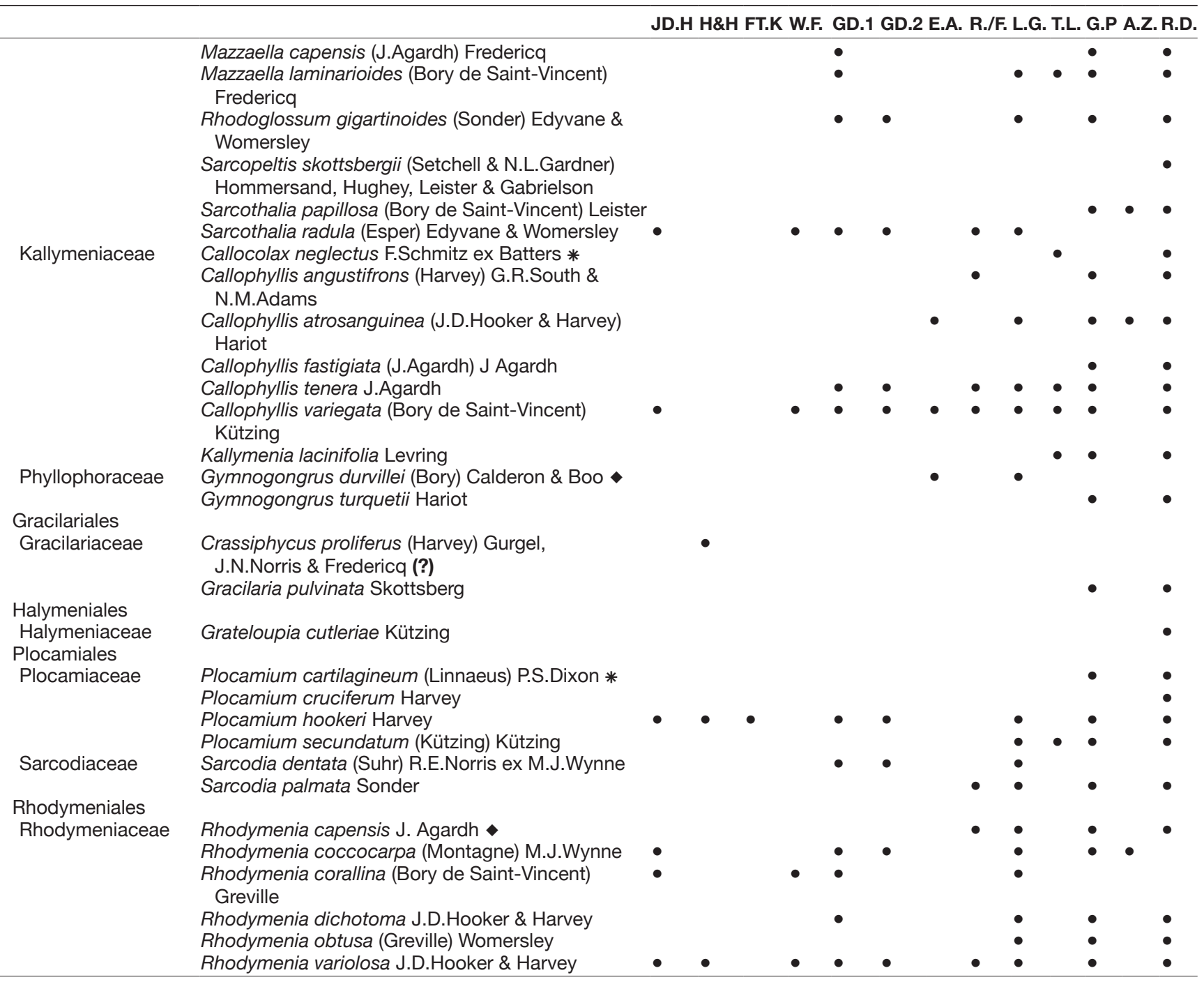

Chlorophyta and the Desmarestiaceae (6 species) in the Phaeophyceae (Fig. 3A). The relatively low proportions of uncertain species names over accepted names as well as the low number of species names also reported in the Northern Hemisphere suggest that taxonomy of Rhodophyta could be currently the most reliable compared to the Phaeophyceae and Chlorophyta (Fig. 3B).

Our knowledge of Kerguelen macroalgae has shown a constant progress through time with a continuous increase of species description along the $20^{\text {th }}$ century to reach the present-day total (166 species), over four times the number of species reported in the first part of the $19^{\text {th }}$ century (39 species) (Fig. 4).

\section{FLORISTIC AFFINITIES OF THE MARINE FLORA OF THE} KERGUELEN ISLANDS IN THE SOUTHERN OCEAN In the Southern Ocean, three species have been reported only from the Kerguelen Islands: the endemic Sphacelaria affinis, the South African Rhodymenia capensis and Gymnogongrus durvillei although considered to be widespread in other oceans. More than a third of the species reported from the Kerguelen Islands have been firstly described in the Northern Hemisphere, which makes it necessary to reassess their taxonomic status (amphi-equatorial species or misidentifications). In total, 51 species are not considered here, 41 of them being described from the Northern Hemisphere, and 7 of them are of doubtful occurrence in the Kerguelen Islands. Consequently, floristic affinities of Kerguelen species were analysed on a selected reliable subset of 115 species over the 166 species from the whole list (Table 3).

The network analysis of occurrence data for the 115 selected species of Kerguelen marine macroalgae relies on no other assumption than the reported species co-occurrence data that determine the network structure (that is, links between species and regions). The network is displayed as a graph (Fig. 5) in which regions are mainly positioned according to 
TABLE 2. - Marine macroalgae described from the Kerguelen Islands: A, species currently accepted taxonomically. B, species reduced at a synonym rank and taxa with uncertain taxonomic status. (1) The Chlorophyta Ulva tessellata J.D.Hooker \& Harvey described from the Kerguelen Islands is a synonym of the fongus Mastodia tessellata (J.D.Hooker \& Harvey) J.D.Hooker \& Harvey.

A

\begin{tabular}{|c|c|c|}
\hline Accepted name & Basyonym & Reference \\
\hline \multicolumn{3}{|l|}{ CHLOROPHYTA (1) } \\
\hline Chaetomorpha kerguelensis Levring & - & Levring 1944 \\
\hline Prasiola cristata (J.D.Hooker \& Harvey in J.D. Hooker) J.Agardh & $\begin{array}{l}\text { Ulva cristata J.D.Hooker \& Harvey in } \\
\text { J.D. Hooker }\end{array}$ & Hooker 1847 \\
\hline Prasiola filiformis Reinsch & - & Reinsch 1890 \\
\hline Rhizoclonium ambiguum (J.D.Hooker \& Harvey) Kützing & $\begin{array}{l}\text { Conferva ambigua J.D.Hooker \& } \\
\text { Harvey }\end{array}$ & Hooker \& Harvey 1845 \\
\hline \multicolumn{3}{|l|}{ OCHROPHYTA - Phaeophyceae } \\
\hline Desmarestia chordalis J.D.Hooker \& Harvey & - & Hooker \& Harvey 1845 \\
\hline Halopteris corymbosa (Dickie) Draisma, Prud'homme \& H.Kawai & Sphacelaria corymbosa Dickie & Dickie $1876 f$ \\
\hline Sphacelaria affinis Dickie & - & Dickie $1876 f$ \\
\hline \multicolumn{3}{|l|}{ RHODOPHYTA } \\
\hline Bostrychia vaga J.D.Hooker \& Harvey & - & Hooker \& Harvey 1845 \\
\hline Carlskottsbergia antarctica (J.D.Hooker \& Harvey) Athanasiadis & $\begin{array}{l}\text { Melobesia verrucata var. antarctica } \\
\text { J.D.Hooker \& Harvey in Harvey \& } \\
\text { J.D. Hooker }\end{array}$ & Hooker 1847 \\
\hline Cladodonta lyallii (J.D.Hooker \& Harvey) Skottsberg & Delesseria lyallii J.D.Hooker \& Harvey & Hooker \& Harvey 1845 \\
\hline Clathromorphum obtectulum (Foslie) W.H.Adey & $\begin{array}{l}\text { Lithothamnion kerguelenum } \mathrm{f} \text {. } \\
\text { obtectula Foslie }\end{array}$ & Foslie 1899 \\
\hline Hildenbrandia kerguelensis (Askenasy) Y.M.Chamberlain & $\begin{array}{l}\text { Hildenbrandia prototypus var. } \\
\text { kerguelensis Askenasy }\end{array}$ & Askenasy 1889 \\
\hline Kallymenia lacinifolia Levring & - & Levring \\
\hline Lithothamnion kerguelenum (Dickie) Foslie & Melobesia kerguelena Dickie & Dickie $1876 f$ \\
\hline Myriogramme kerguelensis Levring & - & Levring 1944 \\
\hline Myriogramme multilobata A.D.Zinova 1963: 56 & - & Zinova 1963 \\
\hline Platyclinia fuscorubra (J.D.Hooker \& Harvey) Levring & $\begin{array}{l}\text { Nitophyllum fuscorubrum } \\
\text { J.D.Hooker \& Harvey }\end{array}$ & Hooker \& Harvey 1845 \\
\hline Plocamium hookeri Harvey in J.D. Hooker \& Harvey & - & Hooker \& Harvey 1845 \\
\hline Plumariopsis eatonii (Dickie) De Toni & Ptilota eatonii Dickie & Dickie $1876 f$ \\
\hline Polycoryne compacta A.D.Zinova & - & Zinova 1963 \\
\hline Polysiphonia urbanoides Levring & - & Levring 1944 \\
\hline Pseudolithophyllum consociatum (Foslie) Me.Lemoine & Lithophyllum consociatum Foslie & Foslie 1905 \\
\hline Pterothamnion simile (J.D.Hooker \& Harvey in Harvey \& J.D.Hooker) Nägeli & $\begin{array}{l}\text { Callithamnion simile J.D.Hooker \& } \\
\text { Harvey in Harvey \& J.D.Hooker }\end{array}$ & Hooker \& Harvey 1845 \\
\hline Rhodymenia variolosa J.D.Hooker \& Harvey & - & Hooker \& Harvey 1845 \\
\hline Synarthrophyton neglectum (Foslie) M.L.Mendoza in Acosta Polo & $\begin{array}{l}\text { Lithothamnion muelleri f. neglecta } \\
\text { Foslie }\end{array}$ & Foslie 1900 \\
\hline
\end{tabular}

B

\begin{tabular}{|c|c|c|}
\hline Basyonym & Reference & Accepted name/Uncertain status \\
\hline \multicolumn{3}{|l|}{ CHLOROPHYTA } \\
\hline Enteromorpha ramellosa Kützing & Kützing 1849 & uncertain taxonomic status \\
\hline Rhizoclonium hookeri Kützing & Kützing 1849 & $\begin{array}{l}\text { Pseudorhizoclonium africanum (Kützing) Boedeker in } \\
\text { Boedeker et al. }\end{array}$ \\
\hline \multicolumn{3}{|l|}{ RHODOPHYTA } \\
\hline Delesseria belayevii A.D.Zinova & Zinova 1963 & Paraglossum lancifolium (J.Agardh) J.Agardh \\
\hline Lithothamnion annulatum Foslie & Foslie 1905 & Phymatolithon lenormandii (Areschoug) W.H.Adey \\
\hline $\begin{array}{l}\text { Rhodymenia hookeri Harvey in J.D.Hooker \& Harvey } \\
\text { (as Rhodomenia hookeri) }\end{array}$ & Hooker \& Harvey 1845 & Calliblepharis fimbriata (Greville) Kützing \\
\hline $\begin{array}{l}\text { Rhodymenia hookeri var. latissima J.D.Hooker \& } \\
\text { Harvey }\end{array}$ & Hooker \& Harvey 1845 & uncertain taxonomic status \\
\hline & uncertain taxonomic status \\
\hline \multicolumn{2}{|c|}{ Rhodymenia hookeri var. prolifera J.D.Hooker \& Harvey Hooker \& Harvey 1845} & uncertain taxonomic status \\
\hline Schizoseris kerguelensis A.D.Zinova & Zinova 1963 & Schizoseris dichotoma (J.D.Hooker \& Harvey) Kylin \\
\hline Schizoseris laciniata f. latiloba A.D.Zinova & Zinova 1963 & Schizoseris condensata (Reinsch) R.W.Ricker \\
\hline
\end{tabular}

their geographical position: South Indian Ocean (Crozet and Kerguelen islands), Magellanic Province (Falkland Islands and Fuegia), South Pacific Ocean (Auckland, Campbell and Macquarie islands), Maritime Antarctica including the South Shetlands and the West Antarctic Peninsula, the Scotia Arc (the South Orkneys Islands and South Georgia). Regions with a low number of co-occurring species (less than 22) are in a more "central" position on the graph. The location of regions is mostly consistent with their geographical position, Heard Island excepted (Fig. 5). The graph structure is mostly stable, whatever the number of computed iterations. Only links to regions with a small number of recorded species (East Ant- 
A

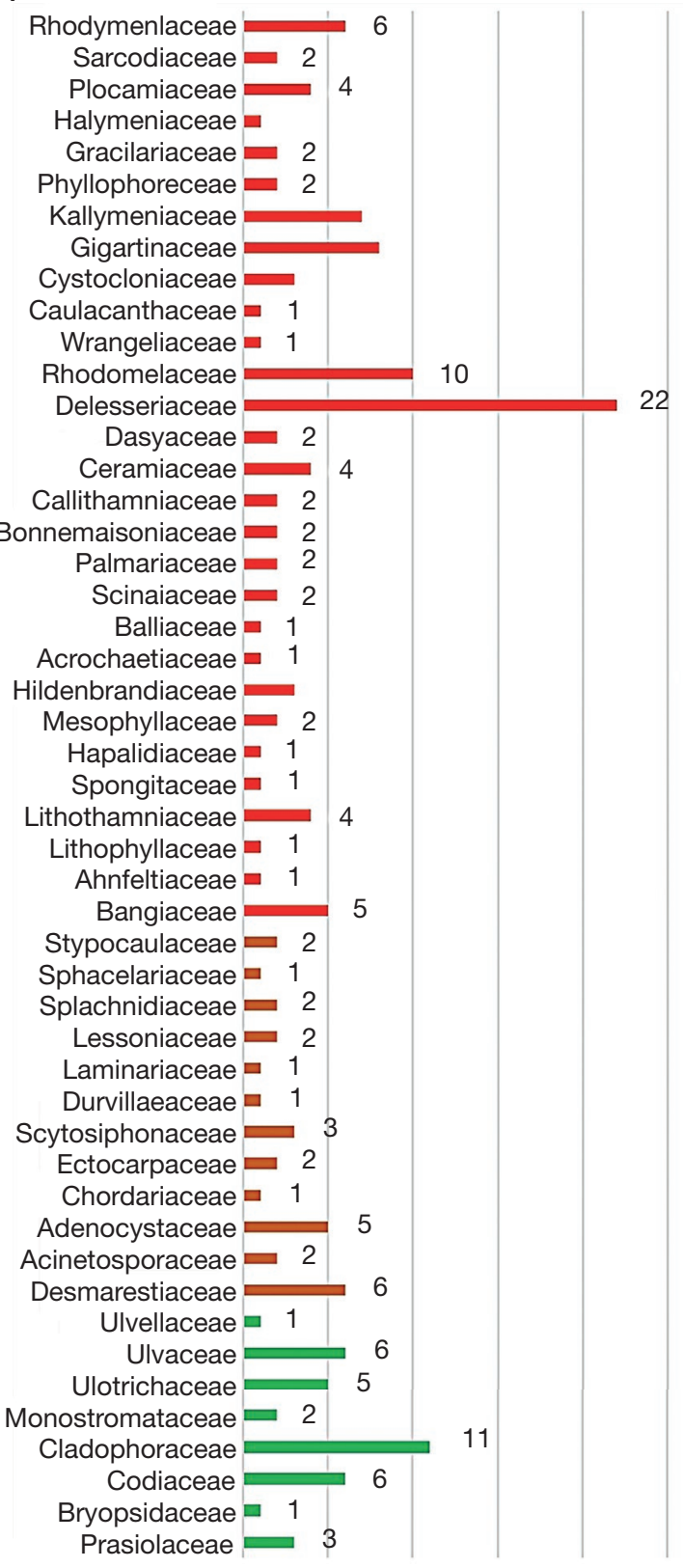

B

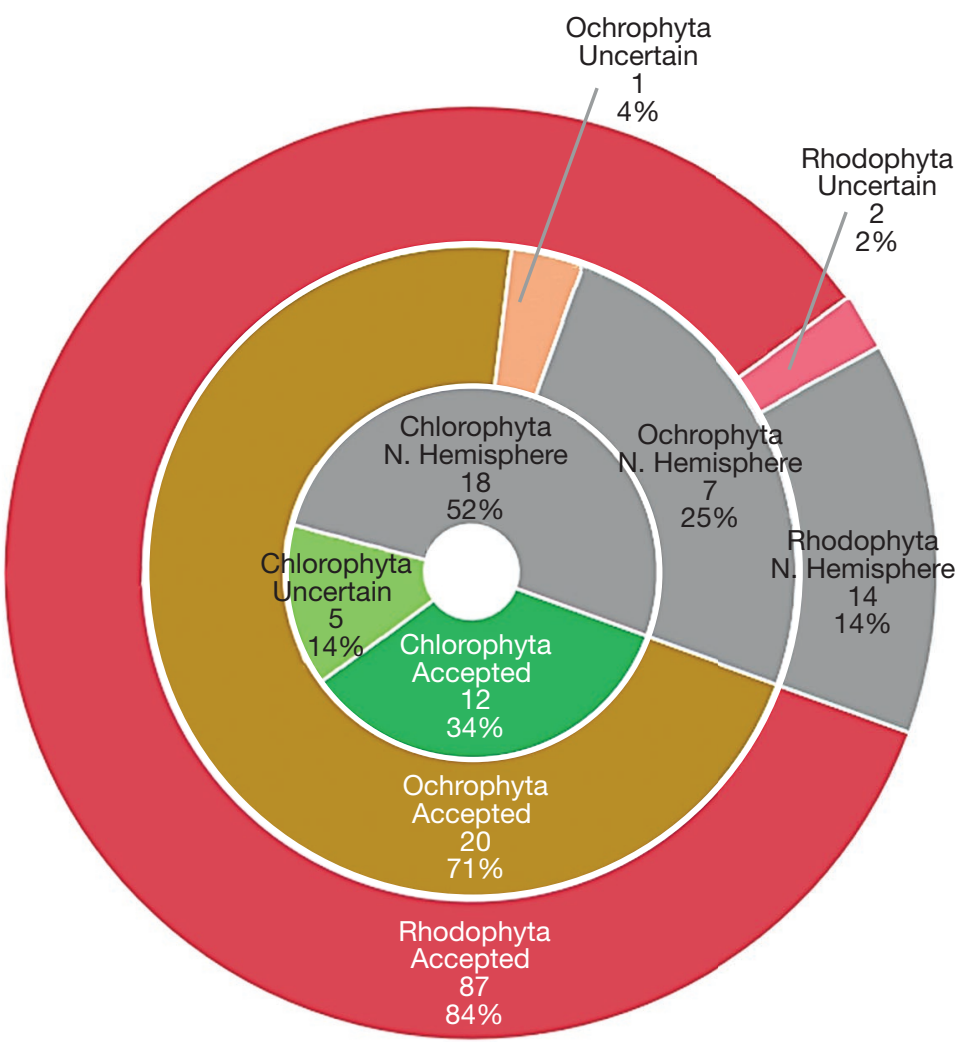

FIG. 3. - A, Number of nominal species per family of marine macroalgae of the Kerguelen Islands; B, taxonomic status (accepted, uncertain, co-occurrence in the Northern Hemisphere) of the species for the three considered phyla (Chlorophyta, Ochrophyta-Phaeophycae and Rhodophyta).

arctica, Marion and Prince Edward Islands, and Saint-Paul and Amsterdam Islands) shift with first iterations until the structure becomes stable.

Based on the current state of our knowledge of species distribution in the 21 considered regions, it appears that most Kerguelen species are also reported in the Magellanic Province: in Fuegia (96 species) and the Falkland Islands (90 species). High co-occurrence levels are also suggested with the Scotia Sea region: South Georgia (64 species), the Sub-Antarctic Islands of Crozet (61 species) and Macquarie (52 species), and the New Zealand Sub-Antarctic Islands of Auckland (64 species) and Campbell (54 species). Co-occurrences are limited with the Antarctic Peninsula (45 species) and the South Shetlands Islands (46 species) (Fig. 1; Table 3). A small number of species are reported to co-occur in other regions of the SO: [1] in the Sub-Antarctic islands: Heard \& McDonald Islands (22 species), Marion and Prince Edward Islands (10 species), and the South Orkney Islands (21 species), [2] along the East Antarctic coasts of Wilkes (13 species), Victoria (17 species), Adélie (10 species), MacRobertson (7 species), Queen Mary (6 species) and Enderby lands (7 species), and [3] in the subtropical islands: Saint Paul (10 species) and Amsterdam Islands (7 species) (Fig. 1; Table 3). 


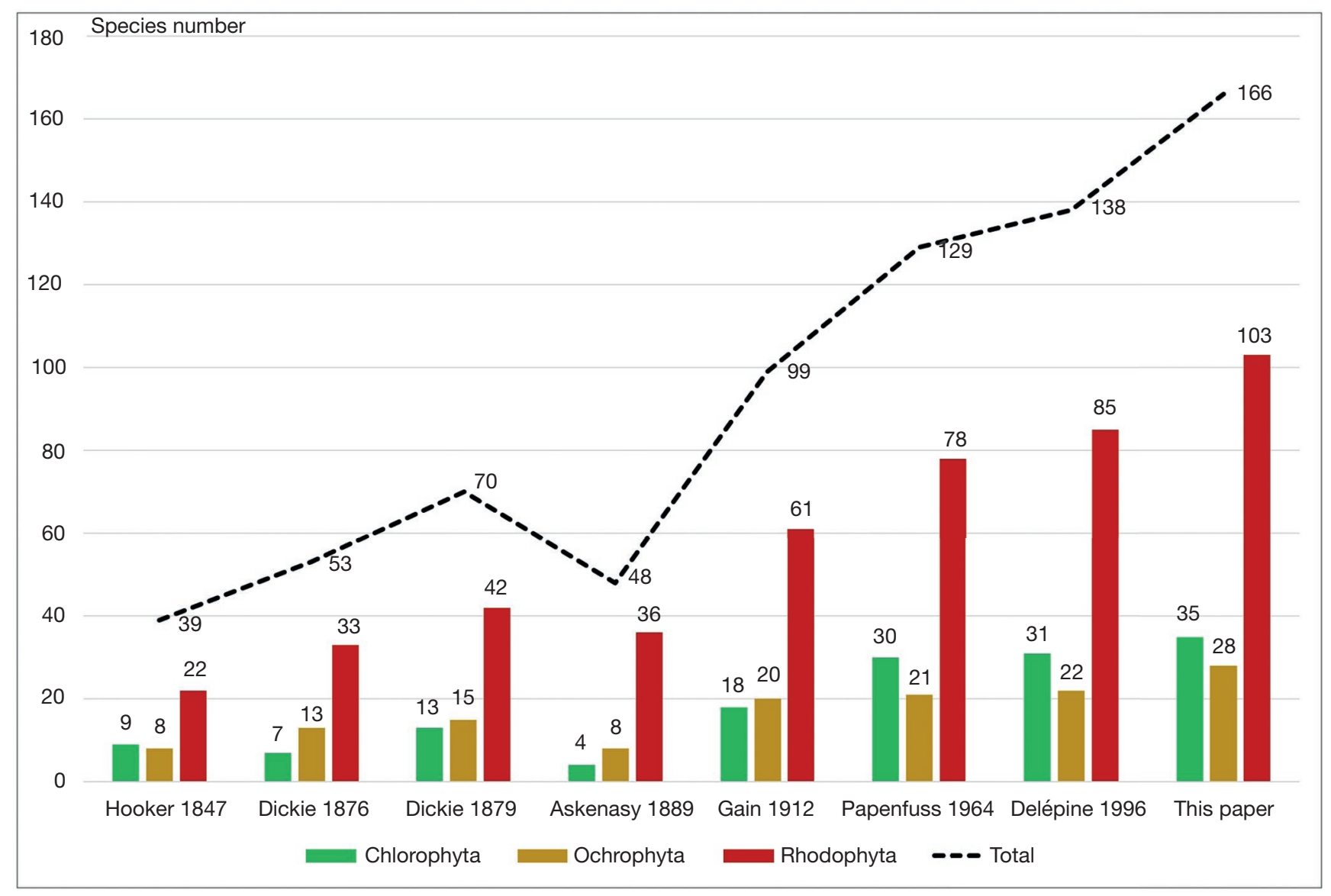

FIG. 4. - Number of marine macroalgae species reported in the Kerguelen Islands since the Ross expedition (1840), in each phylum (Delépine 1996 is a personnal communication to J.-P. Féral).

\section{DISCUSSION}

RELEVANCE OF THE PRESENT INVENTORY AND LIMITATIONS "The taxonomic information available (on the Antarctic marine macroalgal flora) is far from comprehensive and any generalizations should be regarded with caution" (Clayton 1994).

The use of molecular data in algal systematics has increased as high throughput sequencing (HTS) has become more accessible, generating and accelerating the discovery of algal species, also leading to a more stable and natural classification (Oliveira et al. 2018).

However, current available data show that the taxonomy of $\mathrm{SO}$ macroalgae is far from being firmly established and several limitations may impact the interpretation of the present review and updated checklist: 1) some taxa are considered not to be correctly identifiable when not using molecular tools (e.g. genera Ulva, Ulvella, Porphyra, Pyropia); 2) some species have been attributed to Northern Hemisphere taxa solely on the basis of morphological and anatomical criteria (e.g. Ulva spp., Desmarestia spp. or Ceramium spp.); 3) the taxonomy and systematics of several species-rich genera have been updated and new combinations have been proposed, showing that the diversity of this genus was often overestimated [e.g. Polysiphonia Greville (Kim \& Lee 1999; Díaz-Tapia et al. 2017; Bustamante et al. 2021)]; and 4) new or cryptic species were recently discovered in some species or genera of the present inventory [e.g. Callophyllis (Arakaki et al. 2011), Sarcopeltis skottsbergii (Billard et al. 2015, Hughey et al. 2020), Nothogenia (Lindstrom et al. 2015), Phycodrys (Preuss \& Zuccarello 2018), Lessonia (Mansilla et al. 2020)].

\section{CRYPTIC DIVERSITY AND DISTRIBUTION RANGE}

"The observed levels of cryptic diversity in algae, combined with the shift in methods used to characterize them, have resulted in a rampant uncertainty about the status of many older species" (De Clerck et al. 2013).

The increasing use of molecular techniques, have led to much uncertainty about the status of an increasing number of "nominal" species and have revealed the importance of cryptic species (Fraser et al. 2009b; Bittner et al. 2011; González et al. 2012; Lin et al. 2012; De Clerck et al. 2013; Mystikou et al. 2014, 2016; Yang et al. 2014; Billard et al. 2015; Lindstrom et al. 2015; Díaz-Tapia et al. 2018; Dubrasquet et al. 2018; Chenuil et al. 2019; De Jode et al. 2019; Ocaranza-Barrera et al. 2019; Hughey et al. 2020). 
TABLE 3. - Co-occurrence of marine macroalgae in Kerguelen Islands waters and elsewhere in the Southern Ocean. Black crosses (+) correspond to type areas (the presence of two crosses on a same line indicates that the sampling site was not well defined). The cosmopolitan taxa and those described in the North Hemisphere or with uncertain status have not been considered. Sites: AMS, Amsterdam I.; SPA, Saint Paul I.; MAR, Marion I.; PED, Prince Edwards I.; KER, Kerguelen Is.; CRO, Crozet Is.; HEA, Heard and McDonald Is.; MAQ, Macquarie I.; AUK, Auckland I.; Antipodes I.; Stewart I. and South I.; CAM, Campbell I.; FUE, Fuegia; FAL, Falkland Is.; SGI, South Georgia Is.; SSI, South Shetland Is. including King Georges I.; SOI, South Orkney Is.; APE, Antarctic Peninsula; END, Enderby L.; McR, MacRobertson L.; QMA, Queen Mary L.; WIL, Wilkes L.; ADE, Adelie L.; VIC, Victoria L. and Ross Sea. Ecoregions: TSA, Temperate Southern Africa; SUB, Subantarctic Islands; NZS, Subantarctic New Zealand; MAG, Magellanic Province; SCO, Scotia Sea province; CHA, Continental High Antarctic. Geographical coordinates are given Fig. 1 (inset).

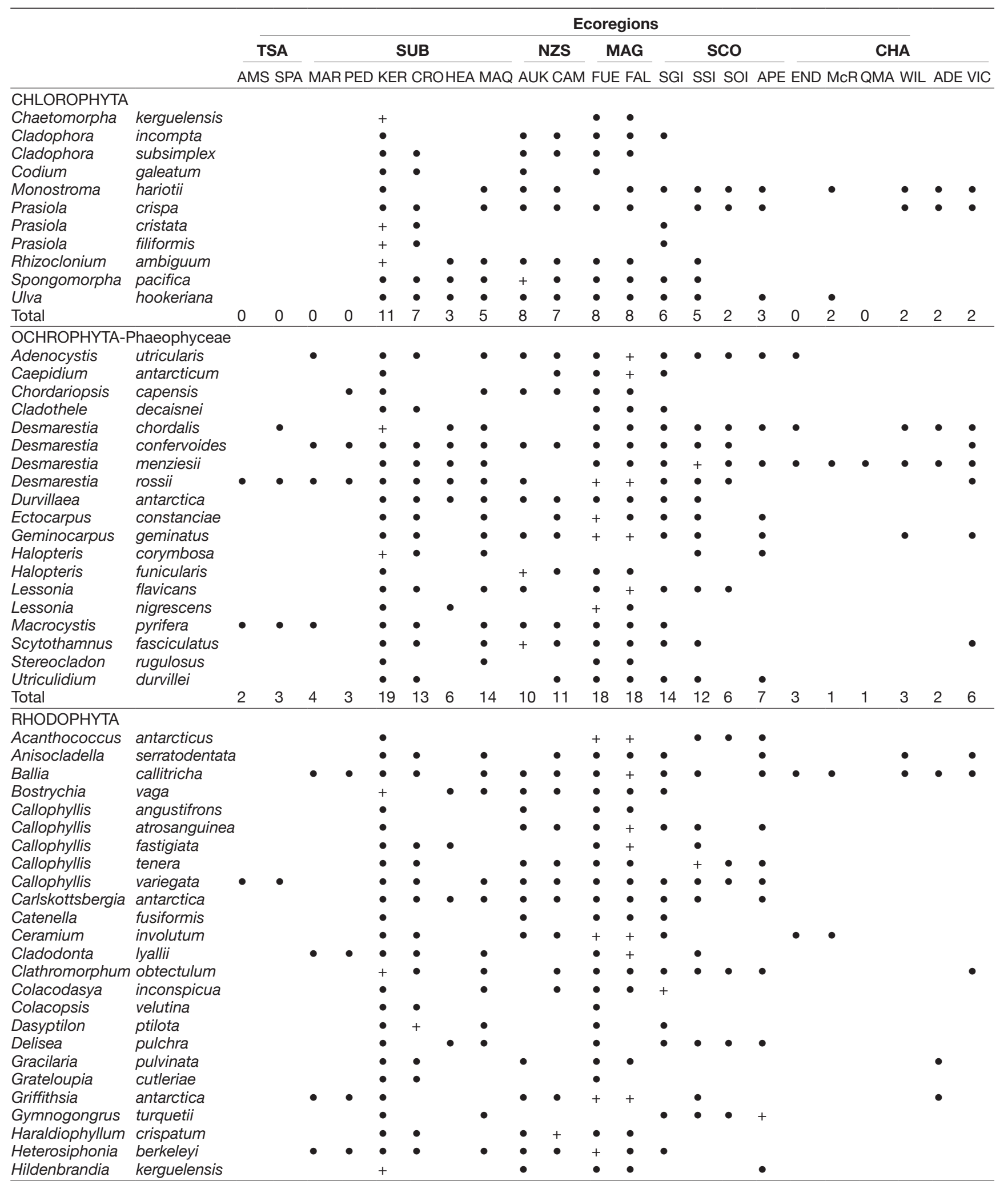


TABLE 3. - Continuation.

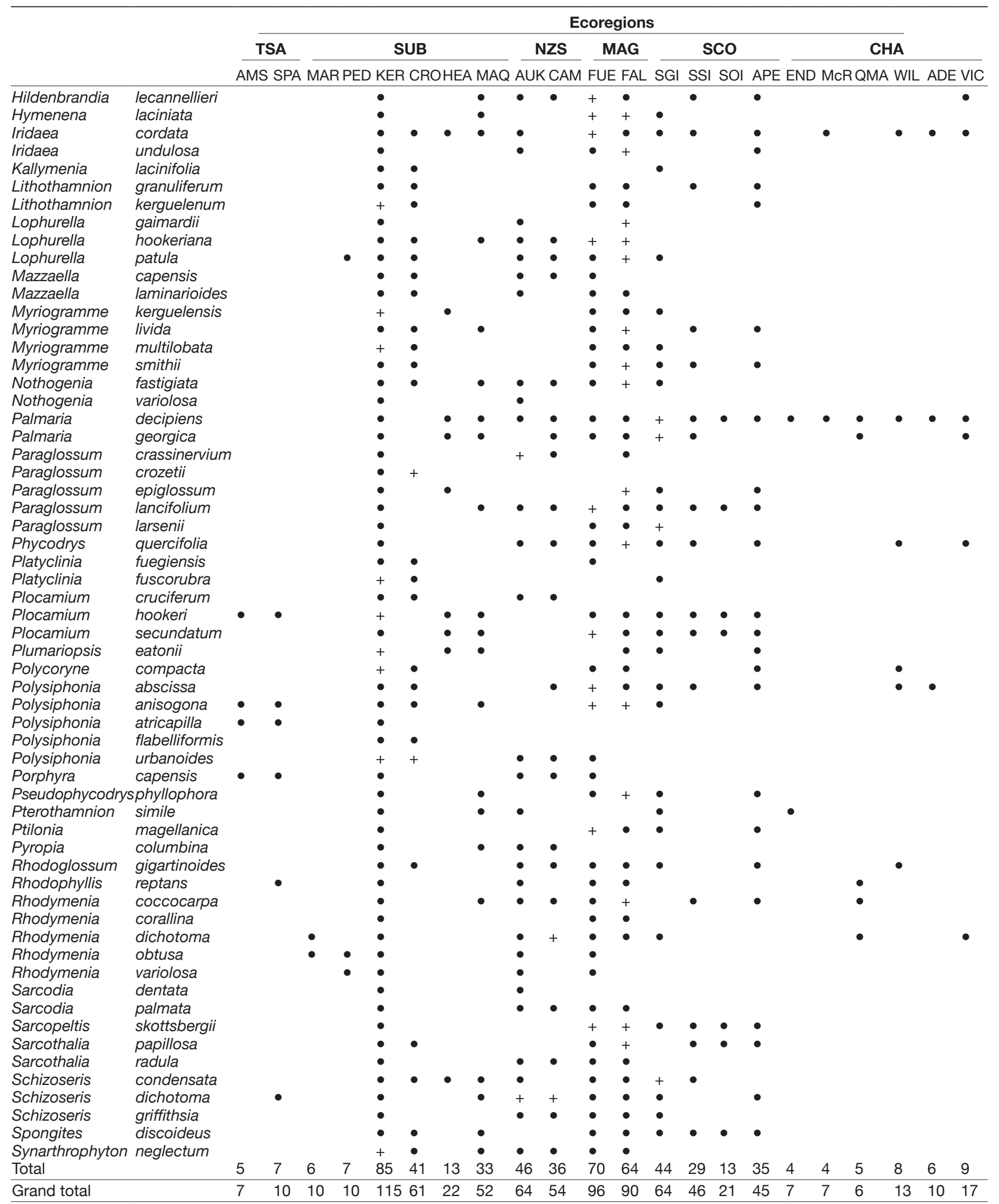

In SO macroalgae, contrasting genetic patterns have been documented, some taxa having wide biogeographical distributions (including the sub-Antarctic zone and Antarctic coasts) while others show narrow range distributions with strong genetic structures and cryptic species (Guillemin et al. 2016; Díaz-Tapia et al. 2018; Ocaranza-Barrera et al. 2019; Hughey et al. 2020). 


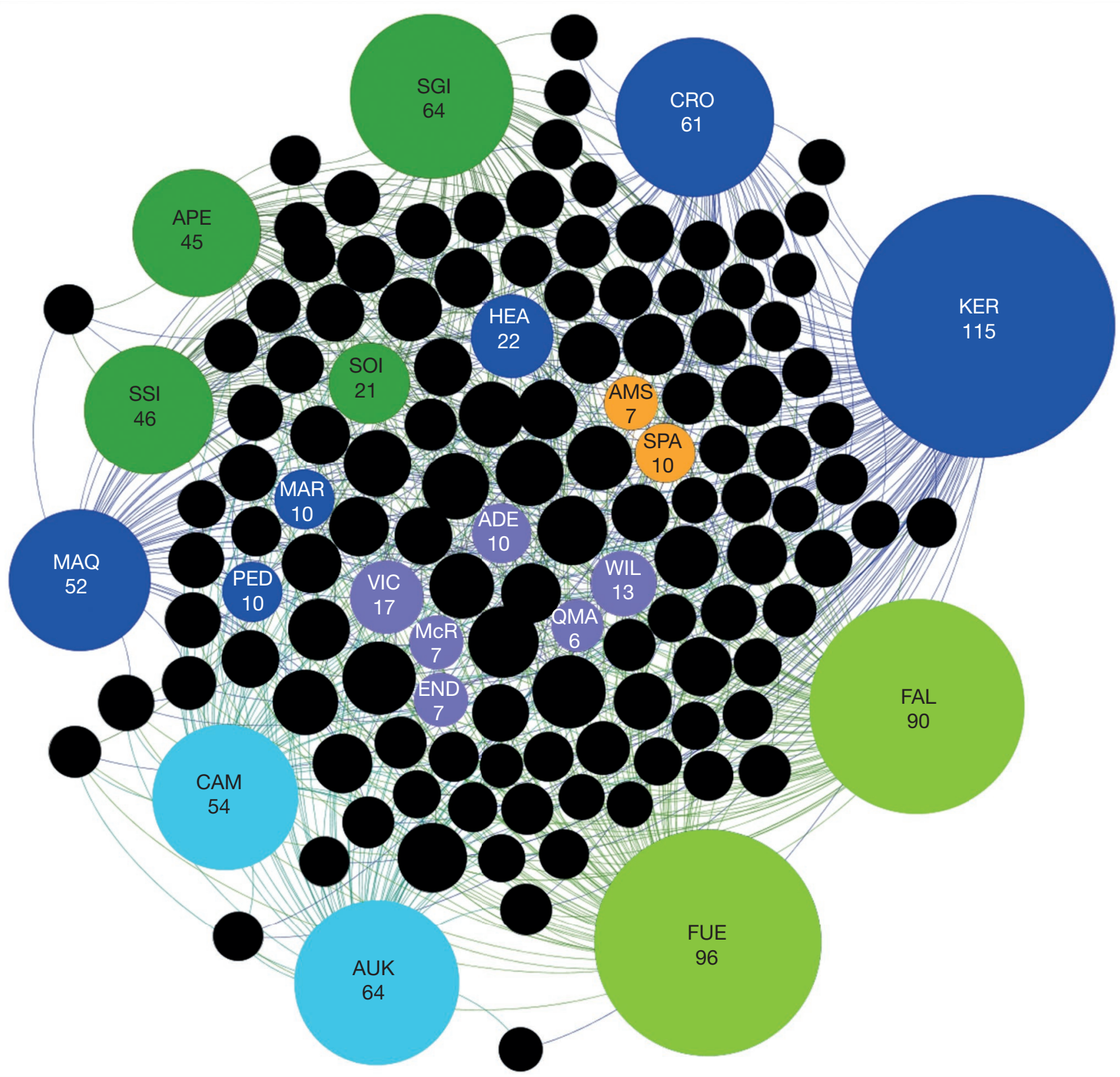

FIG. 5. - Graph of the similarity network between regions (coloured nodes) based on the Kerguelen macroalgae (black nodes) co-occurrence dataset (using ForceAtlas2 layout algorithm). Colour codes are the same as in Figure 1. Nodes size is relative to the number of species co-occurring in the Kerguelen Islands. 51 species of doubtful taxonomic status were not considered. Sites: AMS, Amsterdam I.; SPA, Saint-Paul I.; MAR, Marion I.; PED, Prince Edwards Is.; CRO, Crozet Is.; HEA, Heard and McDonald Is.; MAQ, Macquarie I.; AUK, Auckland Is.; CAM, Campbell Is.; FUE, Fuegia; FAL, Falkland Is.; SGI, South Georgia Is.; SSI, South Shetland Is.; SOI, South Orkney Is.; APE, Antarctic Peninsula; END, Enderby L.; McR, MacRobertson L.; QMA, Queen Mary L.; WIL, Wilkes L.; ADE, Adelie L.; VIC, Victoria L.

The Antarctic marine flora is characterized by a high number of endemic species, approximately $27 \%$ of species restricted to areas south of Antarctic Polar Front, i.e., Antarctica, Antarctic and sub-Antarctic islands (with latitude higher than $55^{\circ} \mathrm{S}$ ) (Oliveira et al. 2020). In its current state, the present inventory reports species with wide distribution ranges and inversely, narrow range and potentially, endemic species. Macroalgae recorded in the Kerguelen Islands include cosmopolitan and highly tolerant species (e.g. genus Ulva and other fouling species) as well as invasive species (e.g. potentially, species such as Codium fragile; Provan et al. 2005). Widely distributed species are also represented by floating algae (e.g. Macrocystis pyrifera, Durvillaea antarctica) (Fraser et al. 2020a, b; Velásquez et al. 2020) or epiphytic species that drift attached to them (e.g. Ballia callitrichia, B. sertularioides (Ávila et al. 2020). However, several Kerguelen algae have been attributed to species with an apparent broad distribution while having low dispersal capacities. These species may also correspond to 
a complex of cryptic species and their identification requires confirmation, like Nothogenia fastigiata, with which seven other species had been confused (Lindstrom et al. 2015). Overall, the high number of mono- or bispecific genera in SO macroalgae suggests that cryptic diversity may have been under-estimated. Compared to species-rich genera such as Callophyllis Kützing, Mazzaella G. De Toni f., Nothogenia Montagne or Paraglossum J.Agardh (Arakaki et al. 2011; Lin et al. 2012; Lindstrom et al. 2015), the genera with few species such as: Acanthococcus J.D.Hooker \& Harvey, Anisocladella Skottsberg, Caepidium J.Agardh, Carlskottsbergia Athanasiadis, Chordariopsis Kylin, Cladodonta Skottsberg, Cladothele J.D.Hooker \& Harvey, Geminocarpus Skottsberg, Plumariopsis De Toni, Polycoryne Skottsberg, Pseudophycodrys Skottsberg, Scytothamnus J.D.Hooker \& Harvey, Stereocladon J.D.Hooker \& Harvey and Utriculidium Skottsberg, would deserve further investigations. In contrast, the monospecific genus Macrocystis is a counterexample, with a very wide distribution, it shows that no general rule should be laid down and that genetic patterns are highly contrasting within $\mathrm{SO}$ macroalgae (Coyer et al. 2001; Macaya \& Zuccarello 2010a, b; Astorga et al. 2012).

Among the problematic species, there are non-floating species (e.g. some species of Durvillaea; Fraser et al. 2020a, b; Velásquez et al. 2020), non-epiphytic encrusting algae (e.g. Corallinaceae; Alongi et al. 2002), non-epiphytic species with a short life cycle (e.g. genera Porphyra, Pyropia; Broom et al. 2010), and some Rhodophyta from the intertidal algal turf (e.g. genus Lophurella; Díaz-Tapia et al. 2020).

The increasing availability of sequences from several cytoplasmic and nuclear DNA regions is beginning to highlight the likely amphi-equatorial distribution of certain species, but this is still less well documented than in the case of Macrocystis pyrifera. A first case study concerns the intertidal species Acrosiphonia arcta (Chlorophyta) and Desmarestia viridis/willii (Phaeophyta), which show extremely similar ITS sequences (Van Oppen et al. 1993). This led Van Oppen et al.(1993) to hypothesize recurrent deep-sea dispersal of microthalli across the equator during cooling temperature events of the Pleistocene with survival to extreme temperature (Last Glacial Maximum, LGM). In a more recent paper, Dubrasquet et al. (2021) highlighted the strong correspondence (>95\%) between sequences of Antarctic species and those obtained for species of Chlorophyta from the Northern Hemisphere such as Acrosiphonia arcta (Dillwyn) Gain, Prasiola crispa (Lightfoot) Kützing and Prasiola antarctica Kützing, confirming the possibility of amphi-equatorial distribution, and also underlining the potential risk of invasion linked to the globalisation of human activities.

\section{SOME Clues ON THE BIOGEOGRAPHy OF KeRGUelen MARINE FLORA}

Our knowledge of SO macroalgae is far from being sufficient for conducting large-scale biogeographical studies. $\mathrm{Hu}$ et al. (2016) reported only 126 papers published on seaweed phylogeography between 1994 and 2014 for the world's flora $(50 \%$ on brown algae, $50 \%$ of which dealt only with
2 genera, Fucus and Sargassum, which do not occur in the $\mathrm{SO})$. Since Hu et al.'s review, seven papers only have been published on Antarctic and sub-Antarctic macroalgae. Overall, the $\mathrm{SO}$ is a key region for which our phylogeographic knowledge is poor, but it is almost reduced to zero for many marine macroalgae.

While keeping in mind all aforementioned limitations, one can note that biogeographical patterns of Kerguelen macroalgae (based on the selected subset of 115 macroalgal species on a total of 166) are partially in line with Spalding et al. (2007)'s regionalization of the SO. In the network analysis (Fig. 5), the Kerguelen Islands cluster together with most other sub-Antarctic regions, including Patagonia and the Falklands, Heard, Crozet and Macquarie islands, and in a less significant manner, with maritime Antarctica including the South Shetlands, the West Antarctic Peninsula and the Scotia Arc islands (South Georgia and the South Orkney Islands). This first grouping corresponds to four biogeographic regions: the south Magellanic Province, South Indian sub-Antarctic islands, New Zealand sub-Antarctic islands, and Macquarie. A second group includes all regions of East Antarctica, generally recognized as a single biogeographic region (Koubbi et al. 2014). Finally, two other smaller groups include 1) Marion/Prince Edwards islands; and 2) Saint-Paul/Amsterdam Islands. The low number of species occurring both in the Kerguelen and in the Saint-Paul/Amsterdam group can be easily explained by the distinct environmental conditions prevailing in sub-Antarctic and subtropical islands. In contrast, the absence of common species in the Marion/Prince Edwards group was less expected and could result from the incompleteness of surveys. Patagonia and the Falkland Islands are the regions where a maximum of species are also recorded, with 83 and $78 \%$ of the 115 Kerguelen species, respectively. This relatively high number of species and genus also occurring in the Magellanic and sub-Antarctic regions has already been observed for other taxonomic groups, such as sponges (Downey et al. 2012), echinoids (Pierrat et al. 2013), starfish (Moreau et al. 2017) and bivalves (Griffiths et al. 2009). Interestingly, this is not a common pattern in gastropods despite the existence of close relationships between algivorous species and macroalgae (Linse et al. 2006; Griffiths et al. 2009, Pierrat et al. 2013).

Molecular data tend to demonstrate that long-distance dispersal across the ocean may represent an effective mechanism if dispersal factors operate steadily over long periods of time, some species succeeding at maintaining a constant gene flow between remote populations (Thiel \& Gutow 2005; Thiel \& Haye 2006; Sanmartín et al. 2007; Macaya et al. 2016; López et al. 2017; Tala et al. 2019). Macroalgae can disperse either through dispersal of vegetative propagules, spores, or zygotes, rafting or accidental human introduction. As for other marine organisms, it was demonstrated that even poor dispersers may reach remote areas (Thiel \& Gutow 2005). Biogeographical affinities between the Kerguelen Islands and the southern Magellanic region likely result from dispersal of diaspores over long distances through the Antarctic Circumpolar Current (ACC) (Waters 2008), and the occurrence of 
similar environmental conditions in both regions facilitating their settlement. The role of the ACC as a dispersal vector is believed to have enabled coastal marine organisms to disperse across the whole sub-Antarctic area since the end of the LGM, as sea ice retreated southward (Fraser et al. 2012). Rafting may have permitted the colonization and "natural" invasion of remote islands (De Queiroz 2005; Thiel \& Gutow 2005; Gillespie et al. 2012; Nikula et al. 2012; Ávila et al. 2020; Macaya et al. 2020). This could be the case for buoyant algae like the bull-kelp Durvillaea antarctica and the giant kelp Macrocystis pyrifera for which passive oceanic drift is believed to be the predominant mechanism of long-distance dispersal (Fraser et al. 2009a, 2010, 2020a, b; Macaya \& Zuccarello 2010a, b; González-Wevar et al. 2016a, b; Moon et al. 2017; Tala et al. 2019).

Effective dispersal and settlement of macroalgae is also determined by intrinsic factors. If dispersal vectors are critical to connectivity between populations, they are often ineffective at maintaining gene flow among populations if local conditions do not permit the survival of propagules ("founders take all"; Waters et al. 2013; see also Montecinos et al. 2012; Fraser et al. 2015; Parada et al. 2017). Kelp rafting is favoured at $\mathrm{mid} / \mathrm{high}$ latitudes but it was suggested that in polar waters (beyond $60^{\circ} \mathrm{S}$ ), low temperatures and light limitations may impede growth of floating seaweeds (Tala et al. 2016). Temperature requirements for growth and survival of some Antarctic-cold temperate and endemic Antarctic species were summarized by Wiencke et al. (2014). Finally, contemporaneous human driven introductions may also have contributed to observed current distribution patterns (Ricciardi 2016; Ricciardi et al. 2017). The accidental dispersal of marine macroalgae over long distances by human activities is attested worldwide (Hewitt et al. 2007, Dubrasquet et al. 2021), and the maritime traffic (hull fouling and ballast waters) is undoubtedly partly responsible for the wide present-day distribution range of some marine species, especially opportunistic and tolerant cryptogenic species (Carlton 1996).

The relatively high number of common species co-occurring in the Kerguelen Islands and South Georgia (70\%), the South Shetlands (56\%) and West Antarctic Peninsula (55\%) challenged an old paradigm that the Antarctic Polar Front (APF) would represent an impervious barrier separating cold Antarctic waters and warmer sub-Antarctic waters, thus preventing north-south dispersal in the SO (Poulin et al. 2014; Chown et al. 2015). A multi-year survey provided evidence that rafting organisms may currently disperse across this front (Fraser $\mathrm{et}$ al. 2017, 2018, 2020a, b). Recent discoveries of non-native kelp species washed up upon some coasts of the Antarctic Peninsula show how red algae species such as Ballia callitricha can also travel through the AFP by rafting (Avila et al. 2020). In addition, Macaya et al. (2020) report a total of 39 species (3 Chlorophyta, 14 Ochrophyta, and 22 Rhodophyta) drifting, stranded or floating in Antarctica or crossing APF and DNA analyses of rafting communities stressed the role of strong wind events to explain biogeographical patterns (Garden et al. 2014). Fraser et al. (2018, 2020a, b) underlined the consequences of the break of the ecological isolation of Antarctica by storm-driven dispersal and warming. This evidence raises questions about the permeability of the APF and the ACC for species dispersal (Avila et al. 2020; Macaya et al. 2020). However, counterexamples exist like the red alga Gigartina skottsbergii Setchell \& N.L. Gardner, described in Fuegia and reported from both South America and Antarctica, a distribution pattern that far exceeds its dispersal capacity. Hughey et al. (2020) showed that lineages from South America and Antarctica, previously assigned to the genus Gigartina Stackhouse, were specifically distinct and had to be positioned in the new genus Sarcopeltis Hommersand, with the South American species $S$. skottsbergii (Setchell \& NLGardner) Hommersand et al. as the holotype species and a new species, S. antarctica Hommersand et al., for the Antarctic Peninsula lineage. Also, studies of mitochondrial marker sequences suggested the persistence of populations on each side of the Drake Passage during glacial maxima and the existence of dispersal barrier due to the reinforcement of the ACC. A similar pattern was recently shown in Iridaea cordata between populations of the Antarctic Peninsula and the Magellanic Province (OcaranzaBarrera et al. 2019).

\section{CONCLUSION}

The present checklist of marine macroalgae of the Kerguelen Islands will certainly be amended in a near future. Molecular works are needed to improve the relevance of taxonomy and our knowledge of species biogeography. The present study is therefore fragmentary and imperfect, but it was intended to constitute a starting point for forthcoming phylogeographical studies. Filling the gaps in our knowledge of SO macroalgae systematics and biogeography implies that integrative molecular and anatomical approaches be adopted using big datasets, as large as possible both in record number and geography. Considering the different fields of research and the huge geographical coverage involved, a concerted international effort is here required.

Macroalgae have developed remarkable adaptations to cope with the high levels of environmental disturbances that are common features of SO marine ecosystems. However, they may be highly vulnerable to present and intensifying threats on marine biota induced by climate change in the region (Guillemin et al. 2020). Along the western Antarctic Peninsula, a recent rapid regional warming with a sea surface temperature (SST) increase of $3.7^{\circ} \mathrm{C}$ per century has been recorded, $87 \%$ of glaciers are retreating, the sea ice season has shortened by about 90 days, and perennial ice does not occur any more at this location. This provides new habitats for algal colonization along rocky coastlines. On the other hand, climatic changes are associated with a higher probability of iceberg calving, and scouring by drifting icebergs may have a highly detrimental effect on benthic assemblages (Müller et al. 2009). The prolonged influx of glacial meltwater reduces salinity and increases water turbidity due to a higher sediment and nutrients load. These nutrient in-put can stimulate phytoplankton growth 
and in turn decrease the availability of light for benthic productivity (Huovinen \& Gómez 2020). High levels of ultraviolet-B radiation (UVBR) due to stratospheric ozone depletion could also induce negative effects on macroalgae (Bartsch et al. 2012). Lastly, global change can also alter in large-scale ocean circulation, gyre and eddy kinetics in the SO, leading to breaches in dispersal barriers (APF and ACC) established since the Eocene / Oligocene transition. When coupled with the intensification of maritime transport (linked to both touristic and scientific activities), these oceanic changes could lead to an increase in propagule pressure and introduction of non-native species (Gómez \& Huovinen 2020a, b; Guillemin et al. 2020; Pellizzari et al. 2020). Climate warming, ozone depletion and invasive species are not the only threats to the Antarctic biota. Among other concerns are ocean acidification and the increase of pollution generating new and not well-understood threats (Gómez \& Huovinen 2020a, b). How other feedbacks related, e.g., with transient and persistent contaminants, ocean acidification and local freshening will impact the underwater light climate in the Antarctic and their consequences for the biota are difficult to predict (Huovinen \& Gómez, 2020). Macroalgae have distinct photosynthetic responses to low temperatures and low irradiance conditions across the $\mathrm{SO}$, with some adaptations demonstrated at the genetic level (Navarro et al. 2019). Local conditions of temperature and salinity can be key factors for their reproductive cycle (e.g. inhibition of spore germination) and their development at high latitudes (Wiencke et al. 2007; Fredersdorf et al. 2009; Rodríguez et al. 2019). For example, Macrocystis pyrifera and Durvillaea antarctica show distinct eco-physiological acclimation patterns of photosynthetic periods according to latitude, the combination of increasing radiation and moderate temperature stimulating growth in both species (Marambio et al. 2017). We can therefore expect that global warming would facilitate the settlement of some macroalgae at higher latitudes (Putman 2018).

In conclusion, complex implications for seaweeds are to be expected from global and local changes, ranging from beneficial to harmful, depending on local processes as well as on the structure and function of macroalgal communities. In the Kerguelen Islands and some other sub-Antarctic islands (e.g. Marion and Macquarie iIslands), a marked climate change, expressed as increases in temperature and declines of in precipitation, has begun to be observed as harbingers of global warming. Because of the proximity of these islands to the APF, a relatively mobile but major marine front, the direct impact of climate shifts and their consequences on the potential invasion of alien species has already drawn the attention of ecologists working on terrestrial ecosystems (Huovinen \& Gómez 2012). However, further studies supported by molecular analyses and biogeographical modelling are needed to infer more consistent information concerning the synergistic or antagonistic effects of on-going environmental changes on marine biota. The present work may constitute a baseline that will prove helpful to track these effects on the SO marine flora.

\section{Acknowledgements}

This research was supported by the French Polar InstituteIPEV (program n ${ }^{\circ} 1044$-Proteker) and the LTSER Zone Atelier Antarctique et Subantarctique (ZATA), France, and the programs PIA CONICYT ACT172065 (GAB) and CONICYT PIA SUPPORT CCTE AFB170008 (IEB), Chile. Thanks are due to Line Le Gall, Bruno de Reviers, Gilberto Marani, (MNHN-Paris) for discussion and documentation, to Alexander Ereskowsky (IMBE) for Russian literature translation, and to Michèle Perret-Boudouresque (MIO), for documentation assistance.

\section{Authors' contributions}

JP.F. conceptualized the review. He performed the literature search and data analysis. He also wrote the original draft. M.V. completed the literature search and validated the taxonomy. All authors provided critical feedback and helped shape the research. Critical revision of the article was more specifically done by M.V. for systematics, by JP.F., E.P. and A.C. for phylogeography, by T.S. and S.R. for ecology and ecophysiology. All authors commented on previous versions of the manuscript. All authors read and approved the final manuscript.

\section{REFERENCES}

Adams N. M. 1994. - Seaweeds of New Zealand. An Illustrated Guide. Canterbury University Press, Christchurch: 8-360.

Alongi G., Cormaci M. \& Furnari G. 2002. - The Corallinaceae (Rhodophyta) from the Ross Sea (Antarctica): a taxonomic revision rejects all records except Phymatolithon foecundum. Phycologia 41 (2): 140-146. https://doi.org/10.2216/i0031-8884-41-2-140.1

Améziane N., Eléaume M., Hemery L. G., Monniot F., Hemery A., Hautecoeur M. \& Dettaï A. 2011. - Biodiversity of the benthos off Kerguelen Islands: overview and perspectives, in Duhamel G. \& WelsFord D. C. (eds), $1^{\text {st }}$ International Scientific Symposium on the Kerguelen Plateau, Concarneau, France. Société Française d'Ichtyologie. Cybium:157-167. https://doi. org/10.26028/cybium/2011-35SP-016

ArakaKi N., Alveal K., Ramírez M. E. \& FredericQ S. 2011. The genus Callophyllis (Kallymeniaceae, Rhodophyta) from the central-south Chilean coast $\left(33^{\circ}\right.$ to $\left.41^{\circ} \mathrm{S}\right)$, with the description of two new species. Revista chilena de historia natural 84 (4): 481-499. https://doi.org/10.4067/S0716-078X2011000400002

ARNAUD P. M. 1974. - Contribution à la bionomie marine benthique des régions antarctiques et subantarctiques. Téthys 6 (3): 467-653

Asensi A. O., Beucher M. \& Delépine R. 1981. — Etude sur la croissance et le développement de Macrocystis pyrifera (L.) C. Ag. aux îles Kerguelen, in FOGG G. E. (ed.), 8th International Seaweed Symposium, Bangor, North Wales. Marine Science Laboratories, Menai Bridge: 278-289.

AsENSI A. O. \& Reviers DE B. 2009. - Illustrated catalogue of types of species historically assigned to Lessonia (Laminariales, Phaeophyceae) preserved at PC, including a taxonomic study of three South-American species with a description of $L$. searlesiana sp. nov. and a new lectotypification of L. flavicans. Cryptogamie, Algologie 30 (3): 209-249. http://sciencepress.mnhn.fr/sites/ default/files/articles/pdf/cryptogamie-algologie2009v30f3a11.pdf

Askenasy E. 1889. - Algen, in Engler A. (ed.), Die Forschungsreise SMS, Gazelle in den Jahren 1874 bis 1876, unter Kommando des Kapitän zur See Freiherrn von Schleinitz. IV. Theil, Botanik, E.S. Mittler und Sohn, Berlin: 1-58, 12. https://www.biodiver- 
sitylibrary.org/item/15609\#page/21/mode/1up

Astorga M. P., Hernández C. E., Valenzuela C. P., AvariaLlautUREO J. \& WeStermeIER R. 2012. — Origin, diversification, and historical biogeography of the giant kelps genus Macrocystis: Evidences from Bayesian phylogenetic analysis. Revista de biologia marina y oceanografia 47 (3): 573-579. https://doi.org/10.4067/ S0718-19572012000300019

Ávila C., Angulo-Preckler C., Martín-Martín R. P., FiguerOla B., Griffiths H. J. \& Waller C. L. 2020. — Invasive marine species discovered on non-native kelp rafts in the warmest Antarctic island. Scientific Reports 10 (1). https://doi.org/10.1038/ s41598-020-58561-y

BARTON E. S. 1902. - XXL Cryptogamia, Algae, in LANKASTER E. R. (ed.), Report on the collections of natural history made in the Antarctic regions during the voyage of the "Southern Cross". British Museum (Natural History), London, 320 p. https://www.biodiversitylibrary.org/item/45289\#page/334/mode/1up

Bartsch I., Wiencke C. \& LAepple T. 2012 - Global seaweed biogeography under a changing climate: the Prospected Effects of Temperature, in WIENCKE C. \& BISCHOF K. (eds) Seaweed Biology. Ecological Studies (Analysis and Synthesis), vol 219. Springer, Berlin, Heidelberg: 383-406. https://doi.org/10.1007/978-3642-28451-9_18

Bastian M., Heymann S. \& Jacomy M. 2009. — Gephi: An Open Source Software for Exploring and Manipulating Networks, In International AAAI Conference on Weblogs and Social Media ICWSM-09, San Jose, California, United States.

Belsher T. \& Mouchot M.-C. 1992. - Evaluation par télédétection satellitaire des stocks de Macrocystis pyrifera dans le Golfe du Morbihan (archipel des Kerguelen). Oceanologica Acta 15 (3): 297-307. https://archimer.ifremer.fr/doc/00100/21163/

Billard E., Reyes J., Mansilla A., Faugeron S. \& Guillemin M.-L. 2015. - Deep genetic divergence between austral populations of the red alga Gigartina skottsbergii reveals a cryptic species endemic to the Antarctic continent. Polar Biology 38 (12): 2021-2034. https://doi.org/10.1007/s00300-015-1762-4

Bittner L., Payri C. E., Maneveldt G. W., Couloux A., Cruaud C., De Reviers B. \& Le Gall L. 2011. - Evolutionary history of the Corallinales (Corallinophycidae, Rhodophyta) inferred from nuclear, plastidial and mitochondrial genomes. Molecular Phylogenetics and Evolution 61 (3): 697-713. https:// doi.org/10.1016/j.ympev.2011.07.019

Boraso De ZAIXsO A. 2013. - Elementos para el estudio de las macroalgas de Argentina. Chubut, Argentina, Comodoro Rivadavia: Universitaria de la Patagonia. 214 p.

Broom J. E. S., Nelson W. A., Farr T. J., Phillips L. E. \& Clayton M. 2010. - Relationships of the Porphyra (Bangiales, Rhodophyta) flora of the Falkland Islands: a molecular survey using rbcL and nSSU sequence data. Australian Systematic Botany 23 (1): 27. https://doi.org/10.1071/SB09033

Bustamante D. E., Won B. Y., Wynne M. J. \& Cho T. O. 2021. - Molecular and morphological analyses reveal new taxa additions to the tribe Streblocladieae (Rhodomelaceae, Rhodophyta). Journal of Phycology https://doi.org/10.1111/jpy.13144

Cárdenas C. A., González-Aravena M. \& Santibañez P. A. 2018. - The importance of local settings: within-year variability in seawater temperature at South Bay, Western Antarctic Peninsula. PeerJ 6: e4289. https://doi.org/10.7717/peerj.4289

CARLTON J. T. 1996. - Biological invasions and cryptogenic species. Ecology 77 (6): 1653-1655. https://doi.org/10.2307/2265767

Chenuil A., Cahill A. E., Délémontey N., Du Salliant Du LuC E. \& FANTON H. 2019. - Problems and questions posed by cryptic species. A framework to guide future studies, in Casetta E., Marques Da Silva J. \& Vecchi D. (eds), From Assessing to Conserving Biodiversity, Conceptual and Practical Challenges, Volume 24. Springer International Publishing, Cham: 77-106. https://doi.org/10.1007/978-3-030-10991-2_4

Chown S. L., Clarke A., Fraser C. I., Cary S. C., Moon K. L. \&
MCGeOCH M. A. 2015. - The changing form of Antarctic biodiversity. Nature 522 (7557): 431-438. https://doi.org/10.1038/ nature 14505

Chung H., OH Y. S., LeE I. K. \& Kim D.-Y. 1994. — Macroalgal vegetation of Maxwell Bay in King George Island, Antarctica. Korean Journal of Phycology 9 (1): 47-58

Chung H., OH Y. S., Kim J. H., Kang Y.-C., Kang S.-H. \& LeE S. 2000. - Species composition and biomass distribution of benthic macroalgae in Maxwell Bay, King George Island, Antarctica. Korean Journal of Polar Research 11 (1): 1-12

Cinelli F., Mendoza M. L. \& Cabioch J. 1989. - Note sur quelques espèces de Corallinacées (Rhodophyta) recoltées dans l'Antarctique. Phycologia 28 (1): 136-139. https://doi.org/10.2216/ i0031-8884-28-1-136.1

Clayton M. N. 1994. - Evolution of the Antarctic marine benthic algal flora. Journal of Phycology 30 (6): 897-904. https://doi. org/10.1111/j.0022-3646.1994.00897.x

Clayton M. N., WienCKe C. \& KlÖSER H. 1997. — New records of temperate and sub-Antarctic marine benthic macroalgae from Antarctica. Polar Biology 17 (2): 141-149. https://doi.org/10.1007/ s003000050116

Conde F. \& Gallardo T. 1991. - Macrofitobentos de la Expedición "Antártida 8611", in IV Simposio Español de Estudios Antárticos, Madrid. Comisión Interministerial de Ciencia y Tecnología (CICYT): 155-157.

Cormaci M., Furnari G. \& SCAmmacca B. 1992. - The benthic algal flora of Terra Nova Bay (Ross Sea, Antarctica). Botanica Marina 35 (6): 541-552. https://doi.org/10.1515/botm.1992.35.6.541

CORMACI M., FURNARI G. \& SCAMMACCA B. 2000. - The macrophytobenthos of Terra Nova Bay, in Faranda F. M., GUglielmo L. \& Ianora A. (eds), Ross Sea Ecology. Springer, Berlin, Heidelberg: 493-502. https://doi.org/10.1007/978-3-642-59607-0_35

Coyer J. A., Smith G. J. \& Andersen R. A. 2001. — Evolution of Macrocystis spp. (Phaeophycae) as determined by ITS1 and ITS2 sequences. Journal of Phycology 37 (4): 574-585. https:// doi.org/10.1046/j.1529-8817.2001.037001574.x

Day J., Dudley N., Hockings M., Holmes G., Laffoley D., STOLTON S. \& Wells S. 2012. - Guidelines for applying the IUCN Protected Area Management Categories to Marine Protected Areas. Gland, Switzerland, International Union for Conservation of Nature and Natural Resources-IUCN. 36 p. (Best Practice Protected Area Guidelines Series; 19). https://portals.iucn.org/ library/sites/library/files/documents/PAG-019-2nd\%20ed.-En.pdf

De Clerck O., Guiry M. D., Leliaert F., Samyn Y. \& VerBRUGGEN H. 2013. - Algal taxonomy: a road to nowhere? Journal of Phycology 49 (2): 215-225. https://doi.org/10.1111/jpy. 12020

De Jode A., David R., Haguenauer A., Cahill A. E., Erga Z., Guillemain D., Sartoretto S., Rocher C., Selva M., Le Gall L., Féral J.-P. \& Chenuil A. 2019. - From seascape ecology to population genomics and back. Spatial and ecological differentiation among cryptic species of the red algae Lithophyllum stictiforme/ $L$. cabiochiae, main bioconstructors of coralligenous habitats. Molecular Phylogenetics and Evolution 137: 104-113. https://doi.org/10.1016/j.ympev.2019.04.005

De QueIroz A. 2005. - The resurrection of oceanic dispersal in historical biogeography. Trends in Ecology \& Evolution 20 (2): 68-73. https://doi.org/10.1016/j.tree.2004.11.006

DELÉPINE R. 1962. - Observations sur la végétation marine des îles australes françaises. Bulletin de la Société Phycologique de France 8: 9-10.

DELÉPINE R. 1964. — Le genre Durvillea dans les îles australes françaises, données préliminaires, Biologie. CNFRA (Comité National Français des Recherches Antarctiques) 1 (7): 141-147

DELÉPINE R. 1966. — La végétation marine dans l'Antarctique de l'Ouest comparée à celle des îles Australes Françaises. Conséquences biogéographiques. Comptes Rendus de la Société de Biogéographie 374: 52-68

DELÉPINE R. 1976. — Note préliminaire sur la répartition des algues 
marines aux îles Kerguelen. CNFRA (Comité National Français des Recherches Antarctiques) 39: 153-159.

DELÉPINE R. 1983. — Les grandes algues aux îles Kerguelen [1. Les ressources]. Biomasse Actualités 12 (spécial 3): 16-17

DELÉPINE R. \& AsENSi A. O. 1975. — Asteronema nov. gen. nouveau genre de Phéophycée australe. Bulletin de la Société botanique de France 122 (7-8): 295-304. https://doi.org/10.1080/00378941 .1975 .10835618

DELÉPINE R. \& ASENSI A. O. 1978. - Réactions écophysiologiques et variations morphogénétiques chez Adenocystis et Utriculidium (Phéophycées). Revue Algologique, Nouvelle Série 13 (1): 43-85; Available at: http://bibliotheques.mnhn.fr/EXPLOITATION/ infodoc/digitalCollections/viewerpopup.aspx?seid=MNHN_ REALG_1978_T013_N001\&i=MNHN_REALG_1978_T013 N001_0003.jpg

DELÉPINE R. \& GRUA P. 1964. — La végétation infra-littorale de la Baie du Morbihan (Kerguelen). Bulletin de la Société Phycologique de France 10: 14

DelÉPINE R. \& HuREAU J.-C. 1966. - Remarques sur l'étagement comparé de la végétation marine aux iles Kerguelen et Crozet (Océan Indien), in Symposium d'Océanographie Antarctique (Santiago, Chili-Septembre 1966). CNFRA, Paris, Vol. 4 (b): 1-3

Delépine R., Asensi A. \& ETCHEVERry H. 1985. — Seaweeds, in FiSHER W. K. \& HUREAU J.-C. (eds), FAO species identification sheets for fishery purposes, Southern Ocean (CCAMLR convention area fishing areas 48,58 and 88), Vol. 1. Food and Agriculture Organization (F.A.O.), Rome: 1-69.

Delépine R., Delesalle B. \& Lambert C. 1979. - Sur l'existence d'un tétrasporophyte dans le cycle de la Rhodophycee Chaetangium fastigiatum (Bory) J. Ag. aux îles Kerguelen. Comptes Rendus Hebdomadaires des Séances de l'Académie des Sciences. Série D: Sciences Naturelles 289: 595-598. Available at: https://gallica. bnf.fr/ark:/12148/bpt6k5496019d/f99.item

Delépine R., LAmb I. M. \& Zimmerman M. H. 1966. — Preliminary report on the marine vegetation of the Antarctic Peninsula, in GORDON Young E. \& MClachlan J. L. (eds), $5^{\text {th }}$ International Seaweed Symposium, Oxford. Pergamon Press: 107-116. https:// doi.org/10.1016/B978-0-08-011841-3.50016-1

Delépine R., Lamb I.M. \& Zimmermann M.H. 1970. — Sur les algues marines antarctiques rapportées au genre Monostroma Thuret. Comptes Rendus Hebdomadaires des Séances de l'Académie des Sciences. Série D: Sciences Naturelles 270: 1973-1976. https:// gallica.bnf.fr/ark:/12148/bpt6k4802850/f2220.item

Díaz-Tapia P., Maggs C. A., Macaya E. C. \& Verbruggen H 2018. - Widely distributed red algae often represent hidden introductions, complexes of cryptic species or species with strong phylogeographic structure. Journal of Phycology 54 (6): 829-839. https://doi.org/10.1111/jpy.12778

Díaz-Tapia P., Maggs C. A., West J. A. \& Verbruggen H. 2017. - Analysis of chloroplast genomes and a supermatrix inform reclassification of the Rhodomelaceae (Rhodophyta). Journal of Phycology 53 (5): 920-937. https://doi.org/10.1111/jpy.12553

díaz-Tapia P., Maggs C. A., Nelson W., Macaya E. C. \& VerBRUGGEN H. 2020. - Reassessment of the genus Lophurella (Rhodomelaceae, Rhodophyta) from Australia and New Zealand reveals four cryptic species. European Journal of Phycology 55 (1): 113-128. https://doi.org/10.1080/09670262.2019.1659419

DicKIE G. 1876a. - Algae collected by H.N. Moseley, Esq., M.A., at Simon's Bey, C.G.H., Seal Island, Marion Island, Kerguelen's Island, and Heard Islands in 15 to 20 fathoms, Contribution of the Botany of HMS "Challenger" XXI. Journal of the Linnean Society of London, Botany 15 (82): 40-41. https://doi. org/10.1111/j.1095-8339.1876.tb00215.x

DiCKIE G. 1876b. - Algae collected by Mr. Moseley at Marion Island, in 40 fathoms., Contributions to the Botany of HMS "Challenger" XXIII. Journal of the Linnean Society of London, Botany 15 (82): 42-43. https://doi.org/10.1111/j.1095-8339.1876.tb00217.x

DiCKIE G. 1876c. - Marine Algae collected by Mr. Moseley at the
Island of Kerguelen., Contributions to the Botany of HMS "Challenger" XXIV. Journal of the Linnean Society of London, Botany 15 (82): 43-47. https://doi.org/10.1111/j.1095-8339.1876.tb00218.x

DiCKIE G. 1876d. - Notes on algae found at Kerguelen Land by the Rev. A.E. Eaton. Journal of the Linnean Society of London, Botany 15 (84): 198-204. https://doi.org/10.1111/j.1095-8339.1876. tb00239.x

DiCKIE G. 1876e. - Algae collected by Mr. Moseley at Heard Island 250 miles S. of Kerguelen., Contributions to the Botany of HMS "Challenger" XXV. Journal of the Linnean Society of London, Botany 15 (82): 47-48. https://doi.org/10.1111/j.1095-8339.1876. tb00219.x

DICKIE G. 1876f. - Notice on some marine algae from Kerguelen Islands. Journal of Botany, Bristish and foreign 14 (new series Volume V): 50-51. https://archive.org/details/journalofbotanyb14trim/page/50

DiCKIE G. 1877. - Supplemental Notes on Algae collected by H. N. Moseley, M.A., of HMS "Challenger" from various localities. (4) Algae from Port Louis, Falkland Islands and Magellan Straits, Contributions to the Botany of HMS "Challenger" XXXVII. Journal of the Linnean Society of London, Botany 15 (88): 487. https://doi.org/10.1111/j.1095-8339.1877.tb00260.x

DiCKIE G. 1879. - Marine algae (exclusive of the Diatomaceae) [of Kerguelen]. An account of the petrological, botanical and zoological collections made in Kerguelen's Land and Rodriguez during the Transit of Venus Expeditions carried out by order of Her Majesty's Government in the years 1874-75. Philosophical Transactions of the Royal Society of London 168 (extra volume): 53-64. https://doi.org/10.1098/rstl.1879.0008

Downey R. V., Griffiths H. J., Linse K. \& Janussen D. 2012.Diversity and distribution patterns in high southern latitude sponges. PLoS ONE 7 (7): e41672. https://doi.org/10.1371/ journal.pone.0041672

Dubrasquet H., Reyes J., Sanchez R. P., Valdivia N. \& GuilLEMIN M.-L. 2018. - Molecular-assisted revision of red macroalgal diversity and distribution along the western Antarctic Peninsula and South Shetland Islands. Cryptogamie, Algologie 39 (4): 409-429. https://doi.org/10.7872/crya/v39.iss4.2018.409

Dubrasquet H., Garrido I., Bruning P., Reyes J. \& GuilLEMIN M.-L. 2021. — Building-up knowledge on green marine macroalgae diversity in the Western Antarctic Peninsula: data from two molecular markers reveals numerous species with amphipolar distribution. Cryptogamie, Algologie 42 (2): 21-37. https://doi. org/10.5252/cryptogamie-algologie2021v42a2

DưCHÊNE J.-C. 1989. - Kerguelen - Recherches au bout du monde. Territoire des Terres Australes et Antarctiques Françaises. Mission de Recherche, Paris, 360 p.

FARLOW W. G. 1876. - Algae, in Kidder J. H., Contributions to the natural history of Kerguelen Island, made in connection with the United States Transit-of-Venus Expedition, 1874-75, Volume II, Botany. Bulletin of the United States National Museum 13 (3): 30-31. https://repository.si.edu/handle/10088/30393

FÉRAL J.-P. \& POULIN E. 2011. — Kerguelen Islands: a living laboratory to understand the benthic biodiversity of the Antarctic, in Duhamel G. \& Welsford D. (eds) 1st International Scientific Symposium on the Kerguelen Plateau, Concarneau, France. Société Française d'Ichtyologie - Cybium: 151-156. https://doi. org/10.26028/cybium/2011-35SP-015

Féral J.-P., Beurier J.-P., Marschal C., Marty G., Motreuil S., Poulin E., Roca J.-C. \& SAUCÈdE T. 2016a. - Kerguelen, un archipel sous haute surveillance. Espèces, Revue d'histoire naturelle 21: 33-39. https://doi.org/10.5281/zenodo.3237853

Féral J.-P., SAucède T., Poulin E., Marschal C., Marty G., Roca J.-C., Motreuil S. \& Beurier J.-P. 2016b. — PROTEKER: implementation of a submarine observatory at the Kerguelen Islands (Southern Ocean). Underwater Technology 34 (1): 1-8. https://doi.org/10.3723/ut.34.003

Féral J.-P., Poulin E., González-Wevar C. A., Améziane N., 
Guillaumot C., Develay E. \& Saucède T. 2019. — Long-term monitoring of coastal benthic habitats in the Kerguelen Islands: a legacy of decades of marine biology research, in WELSFORD D., Dell J.\& Duhamel G. (eds) 2nd Symposium on Kerguelen Platean Marine Ecosystems and Fisheries, Hobart, Tasmania, Australia: 383-402. https://doi.org/10.5281/zenodo.3249143

FosLIE M. 1899. - Some new or critical Lithothamnia. Det Kongelige Norske Videnskabers Selskabs Skrifter 6: 1-19. https://img.algaebase.org/pdf/AC100CF313a1b1444DUkk34889C6/11251.pdf

FosLIE M. 1900. - Calcareous algae from Fuegia in, NORDENSKJÖLD O. (ed.) Svenska expeditionen till Magellanslländerna 1895-1897. Band III (4), Kungliga Boktryckeriet, P.A. Nordstedt och söner, Stockholm: 65-75.

Foslie M. 1905. - Den botaniske samling. Det Kongelige Norske Videnskabers Selskabs Aarsberetning för 1905: 17-24. https:// www.ntnu.no/ojs/index.php/DKNVS_skrifter/article/view/1070

FosLie M. 1908. - Die Lithothamnien der deutschen SüdpolarExpedition 1901-1903, in DrYGALSKI E. vON (ed.), Deutsche Südpolar-Expedition 1901-1903 im Auftrage des Reichsamtes des Innern. Herausgegeben con Erich von Drygalski Leiter Expedition. VIII. Band, Georg Reimer, Berlin: 205-219. https://www.biodiversitylibrary.org/item/41847\#page/31/mode/1up

Fraser C. I., Banks S. C. \& Waters J. M. 2015. - Priority effects can lead to underestimation of dispersal and invasion potential. Biological Invasions 17 (1): 1-8. https://doi.org/10.1007/ s10530-014-0714-1

Fraser C. I., Hay C. H., Spencer H. G. \& Waters J. M. 2009a. Genetic and morphological analyses of the southern bull kelp Durvillaea antarctica (Phaeophyceae: Durvillaeales) in New Zealand reveal cryptic species. Journal of Phycology 45 (2): 436-443. https://doi.org/10.1111/j.1529-8817.2009.00658.x

Fraser C. I., Kay G. M., Plessis M. Du \& Ryan P. G. 2017. Breaking down the barrier: dispersal across the Antarctic Polar Front. Ecography 40 (1): 235-237. https://doi.org/10.1111/ ecog.02449

Fraser C. I., Nikula R., RuZzante D. E. \& Waters J. M. 2012. Poleward bound: biological impacts of Southern Hemisphere glaciation. Trends in Ecology \& Evolution 27 (8): 462-471. https:// doi.org/10.1016/j.tree.2012.04.011

Fraser C. I., NikUla R., Spencer H. G. \& Waters J. M. 2009b. Kelp genes reveal effects of subantarctic sea ice during the Last Glacial Maximum. Proceedings of the National Academy of Sciences 106 (9): 3249-3253. https://doi.org/10.1073/pnas.0810635106

Fraser C. I., Winter D. J., Spencer H. G., \&Waters J. M. 2010. - Multigene phylogeny of the southern bull-kelp genus Durvillaea (Phaeophyceae: Fucales). Molecular Phylogenetics and Evolution 57: 1301-1311. https://doi.org/10.1016/j.ympev.2010.10.011

Fraser C. I., Morrison A. K., Hogg A. M., Macaya E. C., Van Sebille E., Ryan P. G., Padovan A., Jack C., Valdivia N. \& WATERS J. M. 2018. - Antarctica's ecological isolation will be broken by storm-driven dispersal and warming. Nature Climate Change 8 (8): 704-708. https://doi.org/10.1038/s41558-0180209-7

Fraser C. I., Velásquez M., Nelson W. A., Macaya E. C. \& HAY C. H. 2020a. - The biogeographic importance of buoyancy in macroalgae: A case study of the southern bull-kelp genus Durvillaea (Phaeophyceae), including descriptions of two new species. Journal of Phycology 56 (1): 23-36. https://doi. org/10.1111/jpy.12939

Fraser C. I., Morrison A. \& Rojas P. O. 2020b. - 3. Biogeographic Processes Influencing Antarctic and sub-Antarctic Seaweeds, in Gómez I. \& HuOvinen P. (eds) Antarctic Seaweeds. Springer Nature, Cham: 43-57. https://doi.org/10.1007/9783-030-39448-6 3

Fredersdorf J., MÜllLer R., BeCKer S., WiencKe C. \& Bischof K. 2009. - Interactive effects of radiation, temperature and salinity on different life history stages of the Arctic kelp Alaria esculenta (Phaeophyceae). Oecologia 160 (3): 483-492. https://doi. org/10.1007/s00442-009-1326-9

FURMANCZYK K. \& ZIELINSKI K. 1982. - Distribution of macroalgae groupings in shallow waters of Admiralty Bay (King George Island, South Shetland Islands, Antarctic), plotted with the help of air photographs analysis. Polish Polar Research 3 (1-2): 41-47

GAIN L. 1912. - La flore algologique des régions antarctiques et subantarctiques, 2ime expédition antarctique française (1908-1910) commandée par le Dr Jean Charcot, Masson et Cie, Paris: 1-218. https://www.biodiversitylibrary.org/item/31505\#page/7/mode/1up

Gallardo T., Pérez-Ruzafa I. M., Flores-Moya A. \& Conde F. 1999. - New Collections of Benthic Marine Algae from Livingston and Deception Islands (South Shetland Islands) and Trinity Island (Bransfield Strait) Antarctica. Botanica Marina 42 (1): 61-69. https://doi.org/10.1515/BOT.1999.009

Garden C., Currie K., Fraser C. \& Waters J. 2014. — Rafting dispersal constrained by an oceanographic boundary. Marine Ecology Progress Series 501: 297-302. https://doi.org/10.3354/ meps 10675

Gepp A. \& Gepp E. S. 1905a. - Antarctic algae. Journal of Botany, Bristish and foreign 43 (508): 105-109. https://www.biodiversitylibrary.org/item/108522\#page/128/mode/1up

Gepp A. \& GEPP E. S. 1905b. - More Antarctic algae. Journal of Botany, Bristish and foreign 43 (511): 193-196. https://www. biodiversitylibrary.org/item/108522\#page/232/mode/1up

Gepp A. \& GePp E. S. 1907. — Marine algae I.-Phaeophyceae and Florideae, in Zoology and Botany (Invertebrata: Marine Algae, Musci), Volume III, British Museum, London: 1-15. (National Antarctic Expedition (1901-1904), Natural History). https:// www.biodiversitylibrary.org/item/57770\#page/377/mode/1up

Gepp A. \& Gepp E. S. 1912. - Marine algae of the Scottish National Antarctic Expedition, in Report of the Scientific Results of the voyage of SY "Scottia" during the years 1902, 1903 and 1904.Volume III, Botany. The Scottish Oceanographical Laboratory, Edinburgh: 73-83. https://www.biodiversitylibrary.org/ item/75872\#page/105/mode/1 up

Gepp A. \& GEPP E. S. 1917. - Marine algae (excluding Melobesieae), Natural History Report, Botany, (British Antarctic "Terra Nova" expedition 1910-1913), Part II. p. 17-22. https://archive.org/ details/britishantarctic2191gepp

Gillespie R. G., Baldwin B. G., Waters J. M., Fraser C. I., NikUla R. \& Roderick G. K. 2012. — Long-distance dispersal: a framework for hypothesis testing. Trends in Ecology \& Evolution 27 (1): 47-56. https://doi.org/10.1016/j.tree.2011.08.009

Gómez I. \& Huovinen P. (EDS) 2020a - Antarctic Seaweeds: Diversity, Adaptation and Ecosystem services. Springer Nature, Cham. 397 p. https://doi.org/10.1007/978-3-030-39448-6

Gómez I. \& HuOvinen P. 2020b - 1. Antarctic Seaweeds: Biogeography, Adaptation and Ecosystem services, in GóMEZ I. \& Huovinen P. (eds), Antarctic Seaweeds. Springer Nature, Cham.: 3-20. https://doi.org/10.1007/978-3-030-39448-6_1

GonzÁlez A., Beltrán J., Hiriart-Bertrand L., Flores V., De Reviers B., Correa J. A. \& SANTElices B. 2012. - Identification of cryptic species in the Lessonia nigrescens complex (Phaeophyceae, Laminariales): taxonomy of Lessonia nigrescens. Journal of Phycology 48 (5): 1153-1165. https://doi.org/10.1111/j.15298817.2012.01200.x

González-Wevar C. A., Chown S. L., Morley S., Coria N., SAUCÈDE T. \& POUlin E. 2016a. - Out of Antarctica: quaternary colonization of sub-Antarctic Marion Island by the limpet genus Nacella (Patellogastropoda: Nacellidae). Polar Biology 39 (1): 77-89. https://doi.org/10.1007/s00300-014-1620-9

GonzÁlez-Wevar C. A., Hưne M., Rosenfeld S., Saucède T., FÉral J.-P., Mansilla A. \& POUlin E. 2016b. - Patterns of genetic diversity and structure in Antarctic and sub-Antarctic Nacella (Patellogastropoda: Nacellidae) species. Biodiversity 17 (1-2): 46-55. https://doi.org/10.1080/14888386.2016.1181573 Griffiths H. J., BARNES D. K. A. \& Linse K. 2009. — Towards a generalized biogeography of the Southern Ocean benthos. Journal 
of Biogeography 36 (1): 162-177. https://doi.org/10.1111/j.13652699.2008.01979.x

GRUA P. 1963. - Plongées biologiques sous-marines aux îles Saint Paul et de la Nouvelle Amsterdam. CNFRA (Comité National Français des Recherches Antarctiques) 4: 36-50

GruA P. 1964a. - Sur la structure des peuplements de Macrocystis pyrifera (L.) C. Ag. observés en plongée à Kerguelen et Crozet. Comptes Rendus de l'Academie des Sciences Paris, 259: 1541-1543. https://gallica.bnf.fr/ark:/12148/bpt6k40130/f1607.item

GRUA P. 1964b. - Premières données sur les biomasses de l'herbier à Macrocystis pyrifera de la Baie du Morbihan (Archipel Kerguelen). La Terre et la Vie 2: 215-220. http://hdl.handle.net/2042/59096

GRUA P. 1965. - Écologie infralittorale à Kerguelen en scaphandre autonome (Film des Terres Australes et Antarctiques Françaises et du Centre National de la Recherche Scientifique). Revue des TAAF30: 74-79. http://www.archives-polaires.fr/viewer/16039/

GRUA P. 1968. - Aspects of the infralittoral benthos at Archipel de Kerguelen, in Symposium on Antarctic Oceanography, Santiago, Chile. W. Heffer \& Sons Ltd., Cambridge, 164 p.

GRUA P. 1971. - Introduction écologique, P. Grua ed. Invertébrés de l'infralittoral rocheux dans l'archipel de Kerguelen. CNFRA (Comité National Français des Recherches Antarctiques) 30: 1-66

Guillaumot C., Fabri-Ruiz S., Martin A., Eleaume M., Danis B., FÉrAl J.-P. \& SAUCÈde T. 2018. - Benthic species of the Kerguelen Plateau show contrasting distribution shifts in response to environmental changes. Ecology and Evolution 8 (12): 6210 6225. https://doi.org/10.1002/ece3.4091

Guillemin M.-L., Valero M., Tellier F., Macaya E. C., DesTOMBE C. \& FAUGERON S. 2016. - Phylogeography of Seaweeds in the South East Pacific: Complex Evolutionary Processes Along a Latitudinal Gradient, in Hu Z.-M. \& Fraser C. (eds), Seaweed Phylogeography: Adaptation and Evolution of Seaweeds under Environmental Change, Springer Netherlands, Dordrecht: 251-277. https://doi.org/10.1007/978-94-017-7534-2_10

Guillemin M.-L., González-Wevar C., Cárdenas L., DubrasQUeT K., Garrido I., Montecinos A., Ocaranza-Barrera P. \& Flores Robles K. 2020 - 6. Comparative Phylogeography of Antarctic Seaweeds: Genetic Consequences of Historical Climatic Variations, in GómEz I. \& HuOvinEN P. (eds), Antarctic Seaweeds. Springer Nature, Cham.: 103-127. https://doi. org/10.1007/978-3-030-39448-6_6

GuirY M. D. \& Guiry G. M. 2021. - AlgaeBase. World-wide electronic publication, National University of Ireland, Galway. Available from https://www.algaebase.org

Gutt J., Isla E., Bertler A. N., Bodeker G. E., Bracegirdle T. J., Cavanagh R. D., Comiso J.C., Convey P., Cummings V., De Conto R., De Master D., Di Prisco G., D’ovidio F., Griffiths H. J., Khan A. L., López-Martínez J., Murray A. E., Nielsen U. N., OtT S., Post A., Ropert-CoudERT Y., SAUCÈdE T., SCHERER R., SCHIAPARELli S., SCHLOSS I. R., Smith C. R., Stefels J., Stevens C., Strugnell J. M., Trimborn S., Verde C., Verleyen E., Wall D. H., Wilson N. G. \& Xavier J. C. 2018. - Cross-disciplinarity in the advance of Antarctic ecosystem research. Marine Genomics 37: 1-17. https:// doi.org/10.1016/j.margen.2017.09.006

Hariot P. 1889. - Algues, Botanique. Cryptogamie. Paris, Gauthier-Villars et Fils: 3-109. (Mission Scientifique du Cap Horn 1882-1883; tome V). https://www.biodiversitylibrary.org/ item/108173\#page/17/mode/1up

HARVEY W. H. 1847. - Nereis australis, or Algae of the southern ocean: being figures and descriptions of marine plants, collected on the shores of the Cape of Good Hope, the extra-tropical Australian colonies, Tasmania, New Zealand, and the Antarctic regions; deposited in the Herbarium of the Dublin University, Part 1: 1-64. https://www.biodiversitylibrary.org/item/174330\#page/7/ mode/ 1 up

HARVEY W. H. 1849. - Nereis australis, or algae of the southern ocean: being figures and descriptions of marine plants, collected on the shores of the Cape of Good Hope, the extra-tropical Australian colonies, Tasmania, New Zealand, and the Antarctic regions; deposited in the Herbarium of the Dublin University, Part 2: 65-119 [ends abruptly], 14 plates (XXVI-L). https:// www.biodiversitylibrary.org/item/174330\#page/187/mode/1up

Hay C. H. 1986. - A new species of Macrocystis C. Ag. (Phaeophyta) from Marion Island, southern Indian Ocean. Phycologia 25 (2): 241-252. https://doi.org/10.2216/i0031-8884-25-2-241.1

Hay C. H., Adams N. M. \& PARSONS M. J. 1985. - The marine algae of the subantarctic islands of New Zealand: a list of species. National Museum of New Zealand Miscellaneous Series 11: 1-70.

HewitT C. L., CAmpbell M. L. \& SCHAFfelKe B. 2007. — Introductions of seaweeds: accidental transfer pathways and mechanisms. Botanica Marina 50 (5-6): 236-337. https://doi.org/10.1515/ BOT.2007.038

HommerSAND M. H. 2007. - Global biogeography and relationships of the Australian marine macroalgae, in MCCARTHY P. M. \& ORCHARD A. E. (eds), Algae of Australia: Introduction, Australian Biological Resources Study and CSIRO Publishing, Melbourne: 511-542.

Hommersand M. H., Moe R. L., Amsler C. D. \& FredericQ S. 2009. - Notes on the systematics and biogeographical relationships of Antarctic and sub-Antarctic Rhodophyta with descriptions of four new genera and five new species. Botanica Marina 52 (6): 509-534. https://doi.org/10.1515/BOT.2009.081

Hooker J. D. 1847. - LV. Algae, in Hooker J. D. (ed.): The Botany of the Antarctic voyage of HM discovery ships Erebus and Terror, in the years 1839-1843, under the command of Captain Sir James Clark Ross, Kt., R.N., F.R.S., etc. by Joseph Dalton Hooker, M.D., R.N., F.L.S., assistant surgeon of the "Erebus" and botanist to the expedition. Volume 1. Flora antarctica. Part II. Botany of Fuegia, the Falklands, Kerguelen's Land, etc. Reeve Brother, London: 454-519. https://www.biodiversitylibrary.org/ item/22023\#page/490/mode/1up

HoOKer J. D. \& HaRveY W. H. 1845. - Algae antarcticae, being characters and descriptions of the hitherto unpublished species of algae, discovered in Lord Auckland's Group, Campbell's Island, Kerguelen's Land, Falkland Islands, Cape Horn and other southern circumpolar regions, during the voyage of HM discovery ships Erebus and Terror. London Journal of Botany 4: 249-276. https:// www.biodiversitylibrary.org/item/6315\#page/253/mode/1up \& 293-298 https://www.biodiversitylibrary.org/item/6315\#page/297/ mode/ 1 up

Hu Z.-M., Duan D.-L. \& Lopez-Bautista J. 2016. - Seaweed Phylogeography from 1994 to 2014: An Overview, in Hu Z.-M. \& FrASER C. (eds), Seaweed Phylogeography, Springer Netherlands, Dordrecht, p. 3-22. https://doi.org/10.1007/97894-017-7534-2_1

Hughey J. R., Leister G. L., Gabrielson P. W. \& HommerSAND M. H. 2020. - Sarcopeltis gen. nov. (Gigartinaceae, Rhodophyta), with S. skottsbergii comb. nov. from southern South America and $S$. antarctica sp. nov. from the Antarctic Peninsula. Phytotaxa 468 (1): 75-88. https://doi.org/10.11646/ phytotaxa.468.1.4

HuOvinen P. \& Gómez I. 2012 - Cold-Temperate Seaweed Communities of the Southern Hemisphere, in WIENCKE C. \& Bischof K. (eds), Seaweed Biology. Ecological Studies (Analysis and Synthesis), vol. 219. Springer, Berlin, Heidelberg: 293-313. https://doi.org/10.1007/978-3-642-28451-9_14

HuOvinen P. \& Gómez I. 2020 - 7. Underwater Light Environment of Antarctic Seaweeds, in GómEZ I. \& HUOVINEN P. (eds), Antarctic Seaweeds. Springer Nature, Cham.: 131-153. https:// doi.org/10.1007/978-3-030-39448-6_7.

HurEau J.-C. 2011. — Marine research on the Kerguelen Plateau: from early scientific expeditions to current surveys under the CCAMLR objectives, in Duhamel G. \& WelsFord D.C. (eds),

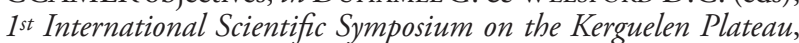
Concarneau, France. Société Française d'Ichtyologie - Cybium: 
5-13. https://doi.org/10.26028/cybium/2011-35SP-002

Jacomy M., Venturini T., Heymann S. \& Bastian M. 2014. ForceAtlas2, a continuous graph layout algorithm for handy network visualization designed for the Gephi Software. PLoS ONE 9 (6): e98679. https://doi.org/10.1371/journal.pone.0098679

John D. M., Pugh P. J. A. \& TitTley I. 1994a. — Observations on the benthic marine algal flora of South Georgia: a floristic and ecological analysis. Bulletin of the natural History Museum, London (botany) 24 (2): 101-114. https://www.biodiversitylibrary. org/item/19427\#page/3/mode/1up

John D. M., Tittley I., Lawson G. W. \& Pugh P. J. A. 1994b. - Distribution of seaweed floras in the Southern Ocean. Botanica Marina 37 (3): 235-239. https://doi.org/10.1515/ botm.1994.37.3.235

Jouventin P., Micol T., Frenot Y. \& Sarano V. 1996. Proposition en vue du classement en réserve naturelle des terres Australes : Kerguelen, Crozet, Saint Paul et Amsterdam. Rapport du comité interministériel de l'environnement polaire. p. 1-194.

Kennicutt M. C., Kim Y. D., Rogan-Finnemore M., Anandakrishnan S., Chown S. L., Colwell S., Cowan D., Escutia C., Frenot Y., Hall J., Liggett D., MCDONAld A. J., Nixdorf U., Siegert M. J., Storey J., WÄhlin A., WeatherWaX A., Wilson G. S., Wilson T., WoOding R., Ackley S., Biebow N., Blankenship D., Bo S., Baeseman J., Cardenas C. A., Cassano J., Danhong C., Dañobeitia J., Francis J., Guldahl J., Hashida G., Corbalan L. J., Klepikov A., LeE J., Leppe M., Lijun F., Lopez-Martinez J., Memolli M., Motoyoshi Y., Bueno R. M., Negrete J., Cardenes M. A. O., Silva M. P., Ramos-Garcia S., Sala H., Shin H., Shijie X., Shiraishi K., Stockings T., Trotter S., Vaughan D.G., De Menezes J. V. D. U., Vlasich V., Weijia Q., Winther J.-G., Miller H., RinToul S. \& YANG H. 2016. - Delivering 21, century Antarctic and Southern Ocean science. Antarctic Science 28 (6): 407-423. https://doi.org/10.1017/S0954102016000481

Kim J. H., Chung H., OH Y. S. \& Lee I. K. 2001a. - Macroalgal Flora of Maxwell Bay, King George Island, Antarctica: I. Chlorophyta, Chrysophyta and Phaeophyta. Ocean and Polar Research 23 (3): 209-221

Kim J. H., Chung H., Oh Y. S. \& LeE I. K. 2001b. — Macroalgal Flora of Maxwell Bay, King George Island, Antarctica: II. Rhodophyta. Ocean and Polar Research 23 (4): 347-360

KIM M. S. \& LEE I. K. 1999. - Neosiphonia flavimarina gen. et sp. nov. with a taxonomic reassessment of the genus Polysiphonia (Rhodomelaceae, Rhodophyta). Phycological Research 47 (4): 271-281. https://doi.org/10.1046/j.1440-1835.1999.00177.x

KlöSER H., QuARTINo M. L. \& WienCKe C. 1996. — Distribution of macroalgae and macroalgal communities in gradients of physical conditions in Potter Cove, King George Island, Antarctica. Hydrobiologia 333 (1): 1-17. https://doi.org/10.1007/ BF00020959

Koubbi P., De Broyer C., Griffiths H.J., Raymond B., D'udekem D’acoz C., Van De Putte A.P., Danis B., David B., Grant S., Gutt J., Held C., Hosie G., Huettmann F., Post A., RopertCoudert Y., Stoddart M., SWadling K.M. \& Wadley V. 2014. - Conclusions: Present and Future of Southern Ocean Biogeography, in De Broyer C., KoubBi P., Griffiths H. J., Raymond B., D'udekem D'acoz C., Van De Putte A. P., Danis B., David B., Grant S., Gutt J., Held C., Hosie G., Huettmann F., Post A. \& Ropert-Coudert Y. (eds), Biogeographic Atlas of the Southern Ocean. Scientific Committee on Antarctic Research (SCAR), Cambridge: 470-475. https://doi. org/10.13140/RG.2.1.1454.1840

KÜTZING F. T. 1849. - Tabulae phycologicae oder Abbildungen der Tange. NordHausen, gedruckt auf Kosten des Verfassers/ self-published. I. Band, p. i-vi, 1-54, 100 Tafeln. http://img. algaebase.org/pdf/5964B9370ed292FBC1TLo110C4EE/1.pdf

KÜTZING F. T. 1855. - Tabulae phycologicae oder Abbildungen der Tange, NordHausen, gedruckt auf Kosten des Verfassers/ self-published. V. Band, p. i-iv, 1-35, 100 Tafeln. https://img. algaebase.org/pdf/5964B9370ed292F0D4tiK10C80F1/5.pdf

KÜTZING F. T. 1856. - Tabulae phycologicae oder Abbildungen der Tange. NordHausen, gedruckt auf Kosten des Verfassers/ self-published. VI. Band, p. i-iv, 1-35, 100 Tafeln. https://img. algaebase.org/pdf/5964B9370ed292F122mYV10C9A31/6.pdf

KÜTZING F. T. 1858. - Tabulae phycologicae oder Abbildungen der Tange. NordHausen, gedruckt auf Kosten des Verfassers/ self-published. VIII. Band, p. i-ii, 1-48, 100 Tafeln. https://img. algaebase.org/pdf/5964B9370ed292F122mYV10C9A31/6.pdf

KÜTZING F. T. 1859. - Tabulae phycologicae oder Abbildungen der Tange. NordHausen, gedruckt auf Kosten des Verfassers/ self-published. IX. Band, p. i-vii, 1-42, 100 Tafeln. https://img. algaebase.org/pdf/5964B9370ed292F209qOn10CFC6D/9.pdf

KÜTZING F. T. 1861. - Tabulae phycologicae oder Abbildungen der Tange. NordHausen, gedruckt auf Kosten des Verfassers/ self-published. XI. Band, p. i-iii, 1-32, 100 Tafeln. https://img. algaebase.org/pdf/5964B9370ed292F2B5rIH10D37E1/11.pdf

KÜTZING F. T. 1865. - Tabulae phycologicae oder Abbildungen der Tange. NordHausen, gedruckt auf Kosten des Verfassers/selfpublished. XV. Band, Band, i-iii, 1-36, 100 Tafeln. https://img. algaebase.org/pdf/5964B9370ed292F3AELkL10DA64F/15.pdf

KÜTZING F. T. 1866. - Tabulae phycologicae oder Abbildungen der Tange. NordHausen, gedruckt auf Kosten des Verfassers/ self-published. XVI. Band, p. i-iii, 1-35, 100 Tafeln. https://img. algaebase.org/pdf/5964B9370ed292EFADPjP10C0F2C/16.pdf

KÜTZING F. T. 1869. - Tabulae phycologicae oder Abbildungen der Tange. NordHausen, gedruckt auf Kosten des Verfassers/ self-published. XIX. Band, p. i-iv, 1-36, 100 Tafeln. https://img. algaebase.org/pdf/5964B9370ed292F4B2sko10E0158/19.pdf

Kylin H. \& SKOTTSBerg C. 1919. — Zur Kenntnis der Subantarktischen und Antarktischen Meeresalgen, II. Rhodophyceen. Wissenschaftliche Ergebnisse der schwedischen Südpolarexpedition 1901-1903. IV. Band, Lieferung 15. Stockholm, Nordenskjöld O. p. 1-88, 1 Tafel. https://www.biodiversitylibrary.org/ pdf4/089461800029953.pdf

LAMB I. M., Zimmerman M. H. \& SMith-BRUnet K. 1975. - Benthic marine algae of the Antarctic Peninsula, in SCHULTZ G. A., Lamb I. M., Lowry J., Tibbs J. F. \& Zimmerman M. H. (eds), Antarctic Research Series, Volume 23. American Geophysical Union, Washington D.C.: 130-227. https://doi.org/10.1029/ AR023p0130

Lambert C., Le Romancer M., Tregarot E. \& Delépine R. 1988. - Les grandes phéophycées d'intérêt économique aux Iles Kerguelen. In Colloque VALVA, Brest. IFREMER, CNRS. p. 169-172. https://archimer.ifremer.fr/doc/00000/1666/

LAWRENCE J. M. 1986. — Proximate composition and standing crop of Durvillaea antarctica (Phaeophyta) in the Bay of Morbihan, Kerguelen (South Indian Ocean). Marine Ecology Progress Series 33: 1-5. https://www.int-res.com/articles/meps/33/m033p001.pdf

LAWRENCE J. M. \& MCCLINTOCK J. B. 1987. - Intertidal Invertebrate and Algal Communities on the Rocky Shores of the Bay of Morbihan, Kerguelen (South Indian Ocean). Marine Ecology 8 (3): 207-220. https://doi.org/10.1111/j.1439-0485.1987.tb00184.x

LAWSON G. W. 1988. - Seaweed distribution patterns as revealed by ordination with reference to the Atlantic and southern Oceans. Helgoländer Meeresuntersuchungen 42: 187-197. https://doi. org/10.1007/BF02366042

Lecomte F., Beall E., Chat J., Davaine P. \& Gaudin P. 2013. - The complete history of salmonid introductions in the Kerguelen Islands, Southern Ocean. Polar Biology 36 (4): 457-475. https://doi.org/10.1007/s00300-012-1281-5

Lemoine P. 1913. - Mélobésiées. Révision des Mélobésiées antarctiques, in 2ème Expédition Antarctique Française (1908-1910) commandée par le Dr. Jean Charcot, Sciences Naturelles: Documents Scientifiques, Botanique. Volume 1, Masson et Cie, Paris, p. 1-67, 2 planches (1-2) https://archive.org/details/deuximeexpdi1913cfran/page/n6 
LEVRING T. 1944. - Meeresalgen von den Crozet-Inseln und Kerguelen. Arkiv för Botanik 31A (8): 1-31

LEVRING T. 1945. - Marine algae from some Antarctic and subAntarctic islands. Lunds Universitets Årsskrift, Ny Följd, Avdelning 2, 41 (7): 1-36, 1 plate

Lin S.-M., FredericQ S. \& Hommersand M. H. 2012. - Molecular phylogeny and developmental studies of Apoglossum and Paraglossum (Delesseriaceae, Rhodophyta) with a description of Apoglosseae trib. nov. European Journal of Phycology 47 (4): 366383. https://doi.org/10.1080/09670262.2012.719164

Lindstrom S. C., Gabrielson P. W., Hughey J. R., Macaya E. C. \& Nelson W. A. 2015. - Sequencing of historic and modern specimens reveals cryptic diversity in Nothogenia (Scinaiaceae, Rhodophyta). Phycologia 54 (2): 97-108. https://doi. org/10.2216/14-077.1

Linse K., Griffiths H. J., Barnes D. K. A. \& Clarke A. 2006. Biodiversity and biogeography of Antarctic and sub-Antarctic Mollusca. Deep Sea Research Part II: Tropical Studies in Oceanography 53 (8-10): 985-1008. https://doi.org/10.1016/j.dsr2.2006.05.003

López B. A., Macaya E. C., Tala F., Tellier F. \& Thiel M. 2017. - The variable routes of rafting: stranding dynamics of floating bull kelp Durvillaea antarctica (Fucales, Phaeophyceae) on beaches in the SE Pacific. Journal of Phycology 53 (1): 70-84. https://doi.org/10.1111/jpy.12479

MACAYA E. C. \&ZuCCARELLO G. C. 2010a. — DNA barcoding and genetic divergence in the giant kelp Macrocystis (Laminariales). Journal of Phycology 46 (4): 736-742. https://doi.org/10.1111/ j.1529-8817.2010.00845.x

Macaya E. C. \& ZuCCARELlo G. C. 2010b. - Genetic structure of the giant kelp Macrocystis pyrifera along the south-eastern Pacific. Marine Ecology Progress Series 420: 103-112. https://doi. org/10.3354/meps08893

Macaya E. C., López B., Tala F., Tellier F. \& Thiel M. 2016. Float and raft: Role of buoyant seaweeds in the phylogeography and genetic structure of non-buoyant associated flora, in Hu Z.-M. \& Fraser C. (eds), Seaweed Phylogeography. Springer Netherlands, Dordrecht: 97-130. https://doi.org/10.1007/97894-017-7534-2_4

Macaya E. C., Tala F., Hinojosa I. A. \& Rothäusler E. 2020. 4. Detached Seaweeds as Important Dispersal Agent Across the Southern Ocean, in Gómez I. \& HuOvinen P. (eds), Antarctic Seaweeds. Springer Nature, Cham.: 59-81. https://doi. org/10.1007/978-3-030-39448-6_4

Macroalgal Herbarium Portal 2020. - The Macroalgal Herbarium Portal. Available from http://macroalgae.org/portal/ collections/index.php

Mansilla A., Gérard K., Boo G. H., Ramirez M. E., OJeda J., Rosenfeld S., Murcia S., Marambio J., GonzÁlez-Wevar C., Calderon M. S., Boo S. M. \& Faugeron S. 2020. — Populations of a new morphotype of corrugate Lessonia Bory in the Beagle Channel, sub-Antarctic Magellanic ecoregion: a possible case of on-going speciation. Cryptogamie, Algologie 41 (11): 105 119. https://doi.org/10.5252/cryptogamie-algologie2020v41a11

Marambio J., RodrÍguez J. P., Mendez F., Ocaranza P., Rosenfeld S., Ojeda J., Rautenberger R., Bischof K., TerraDOS J. \& Mansilla A. 2017. — Photosynthetic performance and pigment composition of Macrocystis pyrifera (Laminariales, Phaeophyceae) along a gradient of depth and seasonality in the ecoregion of Magellan, Chile. Journal of Applied Phycology 29 (5): 2575-2585. https://doi.org/10.1007/s10811-017-1136-0

Mendoza M. L. 1999. - State of knowledge of the Corallinales (Rhodophyta) of Tierra del Fuego and the Antarctic Peninsula. Scientia Marina 63 (Suppl. 1): 139-144. http://scimar.icm.csic. es/scimar/index.php/secId/7/IdNum/63/

Moe R. L. \& DelaCA T. E. 1976. - Occurrence of macroscopic algae along the Antarctic Peninsula. Antarctic Journal of the United States 11 (1): 20-24

Moe R. L. \& Silva P. C. 1977. — Antarctic Marine Flora: Uniquely
Devoid of Kelps. Science 196 (4295): 1206-1208. https://doi. org/10.1126/science. 196.4295 .1206

Moe R. L. \& Silva P. C. 1979. - Morphological and taxonomic studies on Antarctic Ceramiaceae (Rhodophyceae). I. Antarcticothamnion polysporum gen. et sp. nov. British Phycological Journal 14 (4): 385-405. https://doi.org/10.1080/00071617900650441

Moe R. L. \& Silva P.C. 1980. - Morphological and taxonomic studies on Antarctic Ceramiaceae (Rhodophyceae). II. Pterothamnion antarcticum (Kylin) comb. nov. (Antithamnion antarcticum Kylin). British Phycological Journal 15 (1): 1-17. https://doi. org/10.1080/00071618000650011

Moe R. L. \& Silva P. C. 1983. - Morphological and taxonomic studies on Antarctic Ceramiaceae (Rhodophyceae). III. Georgiella and Plumariopsis (Tribe Ptiloteae). British Phycological Journal 18 (3): 275-298. https://doi.org/10.1080/00071618300650291

Montecinos A., Broitman B. R., Faugeron S., Haye P. A., TelLIER F. \& GUILLEMIN M.-L. 2012. — Species replacement along a linear coastal habitat: phylogeography and speciation in the red alga Mazzaella laminarioides along the south east pacific. BMC Evolutionary Biology 12 (1): 97. https://doi.org/10.1186/14712148-12-97

Moon K. L., Chown S. L. \& Fraser C. I. 2017. — Reconsidering connectivity in the sub-Antarctic: Reconsidering connectivity in the sub-Antarctic. Biological Reviews 92 (4): 2164-2181. https:// doi.org/10.1111/brv.12327

Moreau C., Saucède T., Jossart Q., Agüera A., Brayard A. \& DANIS B. 2017. - Reproductive strategy as a piece of the biogeographic puzzle: a case study using Antarctic sea stars (Echinodermata, Asteroidea). Journal of Biogeography 44 (4): 848-860. https://doi.org/10.1111/jbi.12965

Müller R., LaepPle T., BARTSCH I., \& WienCKe C. 2009 — Impact of oceanic warming on the distribution of seaweeds in polar and cold-temperate waters. Botanica Marina, 52 (6): 617-638. https:// doi.org/10.1515/bot.2009.080

Mystikou A., Peters A. F., Asensi A. O., Fletcher K. I., Brickle P., VAn West P., Convey P. \& KÜpper F. C. 2014. - Seaweed biodiversity in the south-western Antarctic Peninsula: surveying macroalgal community composition in the Adelaide Island/ Marguerite Bay region over a 35-year time span. Polar Biology 37 (11): 1607-1619. https://doi.org/10.1007/s00300-014-1547-1 Mystikou A., Asensi A. O., Declerck O., Müller D. G., Peters A. F., Tsiamis K., Fletcher K. I., Westermeier R., Brickle P., VAN West P. \& KÜPper F. C. 2016. — New records and observations of macroalgae and associated pathogens from the Falkland Islands, Patagonia and Tierra del Fuego. Botanica Marina 59 (2-3): 105-121. https://doi.org/10.1515/bot-2015-0071

Navarro N. P., Huovinen P. \& Gómez I. 2019. - Photosynthetic characteristics of geographically disjunct seaweeds: A case study on the early life stages of Antarctic and Subantarctic species. Progress in Oceanography 174: 28-36. https://doi.org/10.1016/j. pocean.2018.11.001

Nelson W. A. \& BRoOM J. E. S. 2010. — The identity of Porphyra columbina (Bangiales, Rhodophyta) originally described from the New Zealand subantarctic islands. Australian Systematic Botany 23 (1): 16-26. https://doi.org/10.1071/SB09032

Nelson W. A., KIM S. Y. \& Boo S. M. 2014. - Transfer of the subantarctic red alga Grateloupia aucklandica to the genus Glaphyrosiphon (Halymeniales, Rhodophyta). Phycologia 53 (5): 457-462. https://doi.org/10.2216/14-017.1

Neushul M. 1961. - Diving in Antarctic waters. Polar Record 10 (67): 353-358. https://doi.org/10.1017/S0032247400051470

Neushul M. 1965. — Diving Observations of Sub-Tidal Antarctic Marine Vegetation. Botanica Marina 8 (2-4): 234-243. https:// doi.org/10.1515/botm.1965.8.2-4.234

Nicod F., Delépine R., Vaquette J. \& Chaumont J.-P. 1988. Activités antibactériennes et antifongiques d'algues marines subantarctiques et méditerranéennes, in Colloque VALVA, Brest. Ifremer, CNRS: 201-204. https://archimer.ifremer.fr/doc/00000/1666/ 
Nikula R., Spencer H. G. \& Waters J. M. 2012. — Passive rafting is a powerful driver of transoceanic gene flow. Biology Letters 9 (1): 20120821. https://doi.org/10.1098/rsbl.2012.0821

Ocaranza-Barrera P., GonZÁlez-WeVar C. A., Guillemin M.-L., Rosenfeld S. \& MANSilla A. 2019. - Molecular divergence between Iridaea cordata (Turner) Bory de Saint-Vincent from the Antarctic Peninsula and the Magellan Region. Journal of Applied Phycology 31 (2): 939-949. https://doi.org/10.1007/ s10811-018-1656-2

Oliveira M. C., RepetTi S. I., Iha C., Jackson C. J., Díaz-Tapia P., Lubiana K. M. F., Cassano V., Costa J. F., CREMEN Ma.C. M., MarCelino V. R. \& Verbruggen H. 2018. — High-throughput sequencing for algal systematics. European Journal of Phycology 53 (3): 256-272. https://doi.org/10.1080/09670262.2018.1441446

Oliveira M. C., Pellizzari F., Medeiros A. S. \& Yokoya N. S. 2020 - 2. Diversity of Antarctic Seaweeds, in GómEZ I. \& Huovinen P. (eds), Antarctic Seaweeds. Springer Nature, Cham. 23-42. https://doi.org/10.1007/978-3-030-39448-6_2

PAPENFuss G. F. 1964a. - Catalogue and bibliography of Antarctic and Sub-Antarctic benthic marine algae, in LEE M. O. (ed.), Antarctic Research Series. Volume 1. Bibliography of the Antarctic Seas: 1-76.

Papenfuss G. F. 1964b. - Problems in the taxonomy and geographical distribution of Antarctic marine algae, in CARRICK R., Holdgate M. \& Prevost J. (eds), Biologie antarctique: 1er symposium organisé par le SCAR, Paris, 2-8 septembre 1962. (Actualités scientifiques et industrielles, Volume 1312), Hermann, Paris. p. 155-160.

Parada G. M., Martínez E. A., Aguilera M. A., Oróstica M. H. \& BroitMAN B.R. 2017. - Interactions between kelp spores and encrusting and articulated corallines: recruitment challenges for Lessonia spicata. Botanica Marina 60 (6): 1-8. https://doi. org/10.1515/bot-2017-0010

Park Y.-H., Durand I., Kestenare E., Rougier G., Zhou M., D’ovidio F., Cotté C. \& Lee J.-H. 2014. - Polar Front around the Kerguelen Islands: An up-to-date determination and associated circulation of surface/subsurface waters. Journal of Geophysical Research: Oceans 119 (10): 6575-6592. https:// doi.org/10.1002/2014JC010061

Pellizzari F., Silva M. C., Silva E. M., Medeiros A., Oliveira M. C., Yokoya N. S., Pupo D., Rosa L. H. \& Colepicolo P. 2017. Diversity and spatial distribution of seaweeds in the South Shetland Islands, Antarctica: an updated database for environmental monitoring under climate change scenarios. Polar Biology 40 (8): 1671-1685. https://doi.org/10.1007/s00300-017-2092-5

Pellizzari F., Rosa L. H. \& YoKOYA N. S. 2020. - 5. Biogeography of Antarctic Seaweeds Facing Climate Changes, in GómEZ I. \& Huovinen P. (eds) Antarctic Seaweeds. Springer Nature, Cham.: 83-102. https://doi.org/10.1007/978-3-030-39448-6_5

Pierrat B., Saucède T., Brayard A. \& David B. 2013. - Comparative biogeography of echinoids, bivalves and gastropods from the Southern Ocean. Journal of Biogeography 40 (7): 1374-1385. https://doi.org/10.1111/jbi.12088

Poulin E., GonZÁleZ-WeVar C., Díaz A., GÉrard K. \& Hüne M. 2014. - Divergence between Antarctic and South American marine invertebrates: What molecular biology tells us about Scotia Arc geodynamics and the intensification of the Antarctic Circumpolar Current. Global and Planetary Change 123 (B): 392-399. https://doi.org/10.1016/j.gloplacha.2014.07.017

PRESCOTT G. W. 1979. - A contribution to a bibliography of Antarctic and Subantarctic algae together with a checklist of freshwater taxa reported to 1977 . Vaduz, Cramer, 312 p. (Bibliotheca Phycologica, Volume 45).

Preuss M. \& ZuCCarello G. C. 2018. - Three new red algal parasites from New Zealand: Cladhymenia oblongifoliaphila sp. nov. (Rhodomelaceae), Phycodrys novae-zelandiaephila sp. nov. (Delesseriaceae) and Judithia parasitica sp. nov. (Kallymeniaceae). Phycologia 57 (1): 9-19. https://doi.org/10.2216/17-36.1
Provan J., Murphy S. \& Maggs C. A. 2005. - Tracking the invasive history of the green alga Codium fragile ssp. tomentosoides. Molecular Ecology 14 (1): 189-194. https://doi.org/10.1111/j.1365294X.2004.02384.x

PutMan N. F. 2018. - Waves of invasion. Nature Climate Change 8 (8): 665-667. https://doi.org/10.1038/s41558-018-0233-7

Quartino M. L., KlöSER H., WienCKe C. \& SChloss I. 2001. Biomass and associations of benthic marine macroalgae from the inner Potter Cove (King George Island, Antarctica) related to depth and substrate. Polar Biology 24 (5): 349-355. https://doi. org/10.1007/s003000000218

RAMíREZ M. E. 2010. - Flora marina bentonica de la region austral de sudamerica y la Antartica. Anales del Instituto de la Patagonia 38 (1): 57-71. https://doi.org/10.4067/S0718-686X2010000100003

ReINBOLD T. 1908. — Die Meeresalgen der deutschen SüdpolarExpedition 1901-1903, in DrygalsKi E. vON (ed.), Deutsche Südpolar-Expedition 1901-1903 im Auftrage des Reichsamtes des Innern. Herausgegeben von Erich von Drygalski Leiter der Expedition. VIII. Band, Botanik, Heft II. Georg Reimer, Berlin, p. 177-202. https://www.biodiversitylibrary.org/item/41847\#page/5/mode/1up REINSCH P. F. 1890. - Zur Meeresalgenflora von Süd-Georgien, in Neumayer G. (ed.), Die internationale Polarforschung 1882-1883: Geschichtlicher Theil und in einem Anhange mehrere einzelne Abhandlungen physikalischen und sonstigen Inhalts. II. Band, 15, (beschreibende Naturwissenschaften), Adolf Ascher \& Cie, Berlin: 366-449. http://img.algaebase.org/pdf/AC100CF3116f313CDBqPm2506E49/18135.pdf

REVIERS DE B. 1980. — Etude biologique d'Adenocystis utricularis et d'Utriculidium durvillei, phéophycées des îles Kerguelen. Thèse de 3ème cycle. Université Pierre et Marie Curie-Paris VI, 63 p.

RICCIARDI A. 2016. - Tracking marine alien species by ship movements. Proceedings of the National Academy of Sciences 113 (20): 5470-5471. https://doi.org/10.1073/pnas.1605152113

Ricciardi A., Blackburn T. M., Carlton J. T., Dick J. T. A., Hulme P. E., Iacarella J. C., Jeschke J. M., Liebhold A. M., Lockwood J. L., MacIsaAc H. J., PYšek P., Richardson D. M., Ruiz G. M., Simberloff D., Sutherland W. J., WarDLE D. A. \& ALDRIDGE D. C. 2017. - Invasion Science: A Horizon Scan of Emerging Challenges and Opportunities. Trends in Ecology \& Evolution 32 (6): 464-474. https://doi.org/10.1016/j. tree.2017.03.007

RICKER R. W. 1987. - Taxonomy and biogeography of Macquarie Island seaweeds, British Museum (Natural History), London, $344 \mathrm{p}$. Rodríguez J. P., Terrados J., Rosenfeld S., Méndez F., Ojeda J. \& MANSILla A. 2019. - Effects of temperature and salinity on the reproductive phases of Macrocystis pyrifera (L.) C. Agardh (Phaeophyceae) in the Magellan region. Journal of Applied Phycology 31 (2): 915-928. https://doi.org/10.1007/ s10811-018-1693-x

SANMARTín I., WANNTORP L. \& WinKWORTH R. C. 2007. — West Wind Drift revisited: testing for directional dispersal in the Southern Hemisphere using event-based tree fitting. Journal of Biogeography 34 (3): 398-416. https://doi.org/10.1111/j.13652699.2006.01655.x

SANNIÉ C. 1951. - XI. Les algues utiles d'Océanie. Revue internationale de botanique appliquée et d'agriculture tropicale 31 (339): 118-119. https://doi.org/10.3406/jatba.1951.6749

Saucède T., Guillaumot C., Michel L.N., Fabri-Ruiz S., Bazin A., Cabessut M., García-Berro A., Mateos A., Mathieu O., De Ridder C., Dubois P., Danis B., David B., Díaz A., Lepoint G., Motreuil S., Poulin E. \& Féral J.-P. 2019. Modelling species response to climate change in sub-Antarctic islands - Echinoids as a case study for the Kerguelen Plateau, in Welsford D., Dell J. \& Duhamel G. (eds), 2nd Symposium on Kerguelen Plateau Marine Ecosystems and Fisheries, Hobart, Tasmania, Australia: 95-116. https://doi.org/10.5281/zenodo.3251680 SkOtTsberg C. 1907. — Zur Kenntnis der subantarktischen und antarktischen Meeresalgen. I. Phaeophyceen, in NORDENSKÖLD O. 
(ed.), Wissenschaftliche Ergebnisse der Schwedischen SüdpolarExpedition 1901-1903, IV. Band, Lieferung 6, P.A. Norstedt \& söner, Stockholm, 172 p. https://www.biodiversitylibrary.org/ item/93213\#page/205/mode/1up

SkOTTSBERg C. 1923. - Botanische Ergebnisse der schwedischen Expedition nach Patagonien und dem Feuerlande 1907-1909. IX. Marine algae. 2. Rhodophyceae. Kungliga Svenska Vetenskapsakademiens Handlingar, Ny Följd, 63 (8): 1-70. http://img. algaebase.org/pdf/5964B9370ee552BF95iTQ3928B94/12296.pdf

SkOTTSBerg C. 1941. - Communities of marine algae in sub-Antarctic and Antarctic waters. Kungliga Svenska Vetenskapsakademiens Handlingar, Avdelning 3, 19 (4): 1-92. http://img.algaebase.org/ pdf/562DF4FA1149b29C70vKT1C0BF75/12297.pdf

SkOTTSBerG C. 1953. - On two collections of Antarctic marine algae. Arkiv för Botanik, Avdelning 2, 2 (7): 531-566, 1 plate.

Sonnerat Herbarium Database 2020. - The Sonnerat Herbarium database of the Muséum National d'Histoire Naturelle, Paris. Available from https://science.mnhn.fr/all/search/form?o riginalCollection $=$ Sonnerat

SOUTH G. R. 1979. - Biogeography of benthic marine algae of the southern oceans, in International Symposium on Marine Biogeography and Evolution in the Southern Hemisphere, 17-20 July 1978, Auckland, New Zealand, New Zealand Department of Scientific and Industrial Research, Wellington: 85-108.

Spalding M. D., Fox H. E., Allen G. R., Davidson N., Ferdana Z. A., Finlayson M., Halpern B. S., Jorge M. A., Lombana A., Lourie S. A., Martin K. D., McManus E., Molnar J., RECCHIA C. A. \& RoberTSON J. 2007. - Marine ecoregions of the world: a bioregionalization of coastal and shelf areas. BioScience 57 (7): 573-583, https://doi.org/10.1641/B570707.

Stenni B., Curran M. A. J., Abram N. J., Orsi A., Goursaud S., Masson-Delmotte V., Neukom R., Goosse H., Divine D., Van Ommen T., Steig E. J., Dixon D. A., Thomas E. R., Bertler N. A. N., Isaksson E., Ekaykin A., Werner M. \& FreZZOTTI M. 2017. - Antarctic climate variability on regional and continental scales over the last 2000 years. Climate of the Past 13 (11): 1609-1634. https://doi.org/10.5194/cp-13-1609-2017

Tala F., Velásquez M., Mansilla A., Macaya E. C. \& Thiel M. 2016. - Latitudinal and seasonal effects on short-term acclimation of floating kelp species from the South-East Pacific. Journal of Experimental Marine Biology and Ecology 483: 31-41. https:// doi.org/10.1016/j.jembe.2016.06.003

Tala F., López B. A., Velásquez M., Jeldres R., Macaya E. C., Mansilla A., Ojeda J. \& Thiel M. 2019. — Long-term persistence of the floating bull kelp Durvillaea antarctica from the South-East Pacific: Potential contribution to local and transoceanic connectivity. Marine Environmental Research 149: 67-79. https://doi.org/10.1016/j.marenvres.2019.05.013

Thiel M. \& GuTOW L. 2005. - The Ecology of Rafting in the Marine Environment. II. The rafting organisms and community, in Gibson R., Gordon J. \& ATKINSON R. (eds), Oceanography and Marine Biology, Volume 43., CRC Press: 279-418. https://www.taylorfrancis.com/books/e/9780429126246/chapters/10.1201/9781420037449-9

Thiel M. \& Haye P. A. 2006. - The Ecology of Rafting in the Marine Environment. III. Biogeographical and evolutionary consequences, in GIBSON R., GORDON J. \& ATKINSON R. (eds), Oceanography and Marine Biology, Volume 44., CRC Press: 323 429; https://www.taylorfrancis.com/books/9780429124044/ chapters/10.1201/9781420006391-10

Van oppen M. J. H., Olsen, J. L., Stam W. T., Van den Hoek, C. \& WIENCKE C. 1993. - Arctic-Antarctic disjunctions in the benthic seaweeds Acrosiphonia arcta (Chlorophyta) and Desmarestia viridis/willii (Phaeophyta) are of recent origin. Marine Biology 115 (3): 381-386

Velásquez M., Fraser C.I., Nelson W. A., Tala F. \& Macaya E. C. 2020. - Concise review of the genus Durvillaea Bory de SaintVincent, 1825. Journal of Applied Phycology 32 (1): 3-21. https:// doi.org/10.1007/s10811-019-01875-w

Waters J. M. 2008. - Driven by the West Wind Drift? A synthesis of southern temperate marine biogeography, with new directions for dispersalism. Journal of Biogeography 35 (3): 417-427. https:// doi.org/10.1111/j.1365-2699.2007.01724.x

Waters J. M., Fraser C. I. \& Hewitt G. M. 2013. - Founder takes all: density-dependent processes structure biodiversity. Trends in Ecology \& Evolution 28 (2): 78-85. https://doi.org/10.1016/j. tree.2012.08.024

WeLls E., BREWIN P. \& BRICKEL P. 2011. — Intertidal and subtidal benthic seaweed diversity of South Georgia. Report for the South Georgia Heritage Trust and Joint Nature Conservation Committee Survey September 2011 Falkland Islands: Shallow Marine Surveys Group, Stanley: 1-20.

WIENCKE C. 1996. - Recent advances in the investigation of Antarctic macroalgae. Polar Biology 16 (4): 231-240. https:// doi.org/10.1007/s003000050049

Wiencke C. \& Amsler C. D. 2012. — Seaweeds and their communities in polar regions, in WIENCKE C. \& BISCHOF K. (eds), Seaweed Biology, vol. 219. Springer, Berlin, Heidelberg: 265-291. https://doi.org/10.1007/978-3-642-28451-9_13

Wiencke C., Amsler C. D. \& Clayton M. N. 2014. - Macroalgae, in De Broyer C., Koubbi P., Griffiths H. J., Raymond B., D’udekem D'acoz C., Van De Putte A.P ., Danis B., David B., Grant S., Gutt J., Held C., Hosie G., Huettmann F., Post A. \& ROPERT-COUderT Y. (eds), Biogeographic Atlas of the Southern Ocean. Scientific Committee on Antarctic Research, Cambridge: 66-73. http://share.biodiversity.aq/Atlas/PDFS/ Atlas Chap.5.1-Wiencke et al_2014-F.pdf

Wiencke C. \& Clayton M. N. 2002. - Antarctic Seaweeds, in WäGELE J. W. (ed.), Synopses of the Antarctic benthos, Volume 9. A.R.G. Gantner Verlag KG, Ruggell, 239 p.

Wiencke C., Clayton M. N., GÓmez I., IKen K., LÜder U. H., Amsler C. D., Karsten U., Hanelt D., Bischof K. \& DunTON K. 2007. - Life strategy, ecophysiology and ecology of seaweeds in polar waters. Reviews in Environmental Science and Bio/Technology 6 (1-3): 95-126. https://doi.org/10.1007/ s11157-006-9106-z

WORMS EDITORIAL BOARD 2021. — World Register of Marine Species. Available from http://www.marinespecies.org at VLIZ. https://doi.org/10.14284/170

WyNNE M. J. 2013. - The red algal families Delesseriaceae and Sarcomeniaceae, Koeltz Scientific Books, Königstein, 326 p.

Yang E. C., Peters A. F., Kawai H., Stern R., Hanyuda T., Bárbara I., Müller D. G., Strittmatter M., Van Reine W. F. P. \& KÜPPER F.C. 2014. - Ligulate Desmarestia (Desmarestiales, Phaeophyceae) revisited: $D$. japonica sp. nov. and $D$. dudresnayi differ from D. ligulata. Journal of Phycology 50 (1): 149-166. https://doi.org/10.1111/jpy.12148

ZANEVELD J. S. 1964. - The benthic algal vegetation of Antarctica. Bulletin of the U.S. Antarctic projects officer 5 (10): 66-69

ZANEVELD J. S. 1966a. - The occurence of benthic marine algae under shore fast-ice in the western Ross Sea, Antarctica, Proceedings of the 5th International Seaweed Symposium, Halifax, August 25-28, 1965.Pergamon Press, Symposium Publications Division: 217-231. https://doi.org/10.1016/B978-0-08-011841-3.50036-7

ZANEVELD J. S. 1966b. - Vertical zonation of Antarctic and subantarctic benthic marine algae. Antarctic Journal of the United States 1 (5): 211-214

ZANEVELD J. S. 1968. - Sub-ice observations of Ross Sea marine algae. Antarctic Journal of the United States 3 (4): 127-128

ZANEVELD J. S. 1988. - The Xanthophyceae and Chlorophyceae of the western Ross Sea, Victoria Land, Antarctica and Macquarie Island collected under the direction of Prof. Dr. J.S. Zaneveld (1963-1967). BLUMEA - Biodiversity, Evolution and Biogeography of Plants 33 (1): 141-180

ZANEVELD J. S. \& SANFORD R. B. 1980. - Crustose corallinaceous algae (Rhodophyta) of the New Zealand and United States Scien- 
tific Expedition to the Ross Sea, Balleny Islands, and Macquarie Ridge, 1965. BLUMEA - Biodiversity, Evolution and Biogeography of Plants 26 (1): 205-231

ZIELINSKI K. 1981. - Benthic macroalgae of Admiralty Bay (King George Island, South Shetland Islands) and circulation of algal matter between the water and the shore. Polish Polar Research $2(3-4): 71-94$

ZIELINSKI K. 1990. — Bottom macroalgae of the Admiralty Bay (King George Island, South Shetlands, Antarctica). Polish Polar Research 11: 95-131

ZiNOVA A. D. 1958. — Sostav i kharakter flory vodorosley u beregov Antarktidy i u ostrovov Kergelen i Makkuori [Composition and character of algal flora at the Antarctic coast and in the vicinity of Kerguelen and Macquarie Islands]. Sovetskaia antarkticheskaia ekspeditsiia. Informatsionnyi biulleten 3: 47-49

ZINOVA A. D. 1963. - Prestaviteli sem. Delesseriaceae (Rhodophyta) u ostrovov Kergelen i Makkurori / Delesseriaceae apud Insulas Kerguelen et Macquarie. [Members of the family Delesseriaceae (Rhodophyta) on Kerguelen and Macquarie Islands]. Trudy Botanicheskogo Instituta Akademii Nauk SSSR, Serie 2, Sporovie Rastenia 16: 52-67.

ZiNOVA A. D. 1966. - Novye dannye o morskikh subantarkticheskikh i antarkticheskikh vodorosliakh [New data on Subantarctic and Antarctic marine algae]. Novosti sistematiki nizshikh rasteniy. 3: 103-109

Zinova A. D. 1973. - Morskie vodorosli iz bukhty Khoupful, ostrov Kergelen [Marine algae from Hopeful Bight, Kerguelen Island]. Novosti sistematiki nizshikh rasteniy. 10: 44-49

Submitted on 13 November 2020; accepted on 6 May 2021; published on 1 September 2021. 


\section{APPENDICES}

APPENDIX 1. - Macroalgae collected during the Ross expedition in the Kerguelen Islands (Hooker 1844-47) consisting in 42 taxa corresponding to 40 currently accepted species names.

\begin{tabular}{|c|c|c|c|}
\hline \multicolumn{2}{|l|}{ accepted name } & reported as & collection site \\
\hline CHLOROPHYTA & & - & - \\
\hline Chaetomorpha linum & (O.F.Müller) Kützing & Conferva linum, Ag. & Christmas Harbour \\
\hline Cladophora rupestris & (Linnaeus) Kützing & Cladophora rupesris, Linn. & Christmas Harbour \\
\hline Codium tomentosum & Stackhouse & Codium tomentosum, Stackh. & - \\
\hline Prasiola cristata & (J.D.Hooker \& Harvey) J.Agardh & Ulva cristata, Hook. fil. et Harv. & Christmas Harbour \\
\hline Rhizoclonium ambiguum & (J.D.Hooker \& Harvey) Kützing & Conferva ambigua, Hook. fil. et Harv. & Christmas Harbour \\
\hline Rhizoclonium riparium & (Roth) Harvey & Cladophora riparia, Roth & Christmas Harbour \\
\hline Ulva compressa & Linneaus & Enteromorpha compressa, Grev. & - \\
\hline Ulva intestinalis & Linneaus & Enteromorpha intestinalis, Link. & - \\
\hline Uncertain status & - & Ulva latissima, Linn. & - \\
\hline \multicolumn{2}{|l|}{ OCHROPHYTA-Phaeophyceae } & 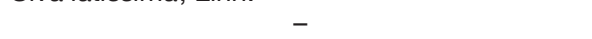 & - \\
\hline Adenocystis utricularis & (Bory de Saint-Vincent) Skottsberg & Adenocystis lessoni, Hook. fil. et Harv. & - \\
\hline Desmarestia chordalis & J.D.Hooker \& Harvey & Desmaresria chordalis, Hook. fil. et Harv. & Christmas Harbour \\
\hline Desmarestia viridis & (O.F.Müller) J.V.Lamouroux & Desmarestia viridis, Lamourx & - \\
\hline Durvillaea antarctica & (Chamisso) Hariot & D'Urvillea utilis, Bory & - \\
\hline- & - & D. $r$ & - \\
\hline Lessonia flavicans & Bory de Saint-Vincent & Lessonia fuscescens, Bory & Christmas Harbour \\
\hline Macrocystis pyrifera & (Linnaeus) C.Agardh & Macrocystis pyrifera, Agardh & - \\
\hline Scytosiphon lomentaria & (Lyngbye) Link & Chorda lomenteria, Grev. & Christmas Harbour \\
\hline Scytothamnus fasciculatus & (J.D.Hooker \& Harvey) A.D.Cotton & Dictyosiphon fasciculatus, Hook. fil. et Harv. & Christmas Harbour \\
\hline RHODOPHYTA & & - & - \\
\hline Ahnfeltia plicata & (Hudson) E.M.Fries & Gigartina plicata, Grev. & Christmas Harbour \\
\hline Ballia callitricha & (C.Agardh) Kützing & Ballia brunonia, Harv. & Christmas Harbour \\
\hline Bostrychia vaga & J.D.Hooker \& Harvey & Stictosiphonia vaga, Hook. fil. et Harv. & Christmas Harbour \\
\hline Callophyllis variegata & (Bory de Saint-Vincent) Kützing & Rhodymenia variegata, Montagne & Christmas Harbour \\
\hline Ceramium diaphanum & (Lightfoot) Roth & Ceramium diaphanum, Ag. & Christmas Harbour \\
\hline Ceramium virgatum & Roth & Ceramium rubrum, Ag. & Christmas Harbour \\
\hline Cladodonta lyallii & (J.D.Hooker \& Harvey) Skottsberg & Delesseria lyallii, Hook. fil. et Harv. & Christmas Harbour \\
\hline Delisea pulchra & (Greville) Montagne & oulchra, Mont. & Christmas Harbour \\
\hline Heterosiphonia berkeleyi & Montagne, & Polysiphonia (Heterosiphonia) berkeleyi, Mont. & - \\
\hline Nothogenia fastigiata & (Bory de Saint-Vincent) P.G.Parkinson & Notogenia variolosa, Mont. & Christmas Harbour \\
\hline Paraglossum crassinervium & $\begin{array}{l}\text { (Montagne) S.-M.Lin, Fredericq \& } \\
\text { Hommersand }\end{array}$ & Delesseria crassinervia, Mont. & Christmas Harbour \\
\hline Platyclinia fuscorubra & (J.D.Hooker \& Harvey) Levring & Nitophyllum fusco-rubrum, Hook. fil. et Harv. & Christmas Harbour \\
\hline Plocamium hookeri & & Plocamium hookeri, Harv. & Christmas Harbour \\
\hline Erythroglossum laciniatum & Lightfoot) Maggs \& Hommersand & Porphyra laciniata, Ag. & - \\
\hline- & - & Ulv & - \\
\hline Porphyra purpurea & (Roth) C.Agardh & Porphyra vulgaris, Ag. & - \\
\hline Pterothamnion simile & (J.D.Hooker \& Harvey) Nägeli & Callithamnion simile, Hook. fil. et Harv. & Christmas Harbour \\
\hline Ptilonia magellanica & (Montagne) J.Agardh & Plocamium ? magellanicum, Hook. fil. et Harv. & - \\
\hline Rhodymenia coccocarpa & (Montagne) M.J.Wynne & Phyllophora cuneifolia, Hook. fil. et Harv. & Christmas Harbour \\
\hline Rhodymenia corallina & (Bory de Saint-Vincent) Greville & Rhodymenia corallina, Bory & Christmas Harbour \\
\hline Rhodymenia variolosa & J.D.Hooker \& Harvey & Rhodymenia variolosa, Hook. fil. et Harv. & Christmas Harbour \\
\hline Sarcothalia radula & (Esper) Edyvane \& Womersley & Iridaea radula, Bory & - \\
\hline Titanoderma pustulatum & (J.V.Lamouroux) Nägeli & Melobesia verrucata, Lamx. & - \\
\hline
\end{tabular}


APPENDIX 2. - Macroalgae from the Kerguelen Islands reported by Kützing (1849, 1855, 1856, 1858, 1859, 1861, 1865, 1866, 1869).

accepted name

CHLOROPHYTA

Prasiola cristata

Ulva compressa

Uncertain status

OCHROPHYTA Phaeophyceae

Adenocystis utricularis

Desmarestia chordalis

Desmarestia viridis

Lessonia flavicans

RHODOPHYTA

Ahnfeltia plicata

Ballia callitricha

Bostrychia vaga

Callophyllis variegata

Nothogenia variolosa

Paraglossum crassinervium

Plocamium hookeri

Pterothamnion simile

Ptilonia magellanica

Rhodymenia variolosa

\section{reported as}

(J.D.Hooker \& Harvey) J.Agardh

Linnaeus

(Bory de Saint-Vincent) Skottsberg

J.D.Hooker \& Harvey

(O.F. Müller) J.V. Lamouroux

Bory de Saint-Vincent

(Hudson) E.M.Fries

(C.Agardh) Kützing

J.D.Hooker \& Harvey

(Bory de Saint-Vincent) Kützing

(Montagne) Montagne

(Montagne) S.-M.Lin, Fredericq \& Hommersand

Harvey

(J.D.Hooker \& Harvey) Nägeli

(Montagne) J.Agardh

J.D. Hooker \& Harvey
Ulva (?) cristata Hook fil. \& Harvey

Enteromorpha complanata Kützing

Enteromorpha ramellosa Kützing

Adenocystis lessonii major

Desmarestia chordalis Hook. fil. et Harvey

Desmarestia viridis Lamour.

Lessonia fuscescens Bory

Gymnogongrus plicatus Kützing

Ballia callitricha Mont.

Bostrychia vaga Hook. fil.. \& Harv.

Callophyllis variegata f. pulcherrima Hook. fil.

Nothogenia variolosa Montagne

Hypoglossum crassinervium Kützing

Plocamium hookeri Harvey

Callithamnion simile Hook. fil. \& Harvey

Thamnocarpus magellanicus Kützing

Epymenia variolosa Küttzing 
APPENDIX 3. - Macroalgae collected during the Challenger expedition by H.N. Moseley (Dickie 1876a, c) and during the English Venus transit expedition by A.E. Eaton (Dickie 1876d). Sampling sites were in the Baie du Morbihan (Royal Sound) and in the Swains's Bay (Fig. 2).

\begin{tabular}{|c|c|c|c|}
\hline \multicolumn{2}{|l|}{ accepted name } & reported as & collection sites \\
\hline CHLOROPHYTA & & - & - \\
\hline Acrosiphonia arcta & (Dillwyn) Gain & Cladophora arcta Ktz. & $\begin{array}{l}\text { Observatory Bay, Royal } \\
\text { Sound }\end{array}$ \\
\hline Bryopsis plumosa & (Hudson) C.Agardh & Bryopsis plumosa Grev. & Observatory Bay \\
\hline Cladophora flexuosa & (O.F.Müller) Kützing & Cladophora flexuosa Griff. & Observatory Bay \\
\hline Cladophora subsimplex & Kützing & $\begin{array}{l}\text { Cladophora simpliciuscula H. f. \& } \\
\text { Harv. }\end{array}$ & Observatory Bay \\
\hline Codium adhaerens & C.Agardh & Codium adhaerens Ag. & Swain's Bay \\
\hline Ulva compressa & Linneaus & Enteromorpha compressa Link & \\
\hline Uncertain status & - & Ulva latissima & Swain's Bay \\
\hline OCHROPHYTA-Phaeophyceae & & 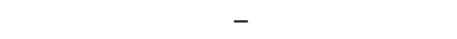 & \\
\hline Adenocystis utricularis & (Bory de Saint-Vincent) Skottsberg & Adenocystis lessonii H. f. \& Harv. & Observatory Bay \\
\hline Colpomenia sinuosa & (Mertens ex Roth) Derbès \& Solier & Asperococcus sunuosus Roth. & \\
\hline Desmarestia chordalis & J.D.Hooker \& Harvey & Desmarestia chordalis H.f. \& Harv. & \\
\hline Desmarestia menziesii & J.Agardh & Desmarestias media Grev. & \\
\hline Desmarestia rossi & J.D.Hooker \& Harvey & Desmarestia rossi H.f. \& Harv. & Observatory Bay \\
\hline Desmarestia viridis & (O.F.Müller) J.V.Lamouroux & Desmarestia viridis Grev. & Observatory Bay \\
\hline Durvillaea antarctica & (Chamisso) Hariot & D'urvillea utilis, Bory & \\
\hline Elachista flaccida & (Dillwyn) Fries & Elachista flaccida Aresch & Royal Sound \\
\hline Geminocarpus geminatus & (J.D.Hooker \& Harvey) Skottsberg & Ectocarpus geminatus H. f. \& Harv. & Observatory Bay \\
\hline Halopteris corymbosa & (Dickie) Draisma, Prud'homme \& H.Kawai & Sphacelaria corymbosa n.sp. & \\
\hline Halopteris funicularis & (Montagne) Sauvageau & Sphacelaria funicularis Mont. ? & Observatory Bay \\
\hline Macrocystis pyrifera & (Linnaeus) C.Agardh & Macrocystis pyrifera Ag. & Observatory Bay \\
\hline Sphacelaria affinis & Dickie & Sphacelaria affinis & - \\
\hline RHODOPHYTA & & - & - \\
\hline Ahnfeltia plicata & (Hudson) E.M.Fries & Ahnfeltia plicata Huds. & - \\
\hline Ballia callitricha & (C.Agardh) Kützing & Ballia callitricha Ag. & Observatory \\
\hline Callophyllis tenera & J.Agardh & Calophyllis tenera J. Ag. & Swain's Bay \\
\hline Callophyllis variegata & (Bory de Saint-Vincent) Kützing & Calophyllis variegata Bory & Swain's Bay \\
\hline Carlskottsbergia antarctica & (J.D.Hooker \& Harvey) Athanasiadis & Melobesia lichenoides Ell. \& Sol. & Observatory Bay \\
\hline Ceramium virgatum & Roth & Ceramium rubrum Ag. & - \\
\hline Cladodonta Iyallii & (J.D.Hooker \& Harvey) Skottsberg & Delesseria lyallii H. f. \& Harv. & Swain’s Bay \\
\hline Dasyptilon ptilota & (J.D.Hooker \& Harvey) Athanasiadis & Callithamnion ptilota H. \& H. & Swain's Bay \\
\hline Erythroglossum laciniatum & (Lightfoot) Maggs \& Hommersand & Porphyra laciniata Ag. & Observatory Bay \\
\hline Heterosiphonia berkeleyi & Montagne & Dasya berkeleyi Mont. & $\begin{array}{l}\text { Swain's Bay, Observatory } \\
\text { Bay }\end{array}$ \\
\hline Hymenena laciniata & (J.D.Hooker \& Harvey) Kylin & Nitophyllum laciniatum H. f. \& Harv. & Swain's Bay \\
\hline Lithothamnion kerguelenum & Foslie & Melobesia kerguelena n.sp. & Swain's Bay \\
\hline Lophurella gaimardii & (Gaudichaud ex C.Agardh) De Toni & Rhodomela gaimardi Mont. & Swain's Bay \\
\hline Lophurella hookeriana & (J.Agardh) Falkenberg & Rhodomela hookeriana J. Ag. & Swain's Bay \\
\hline Myriogramme livida & (J.D.Hooker \& Harvey) Kylin & Nitophyllum lividum H. f. \& Harv. & Swain's Bay \\
\hline Nothogenia fastigiata & (Bory de Saint-Vincent) P.G.Parkinson & Chaetangium variolosum Mont. & $\begin{array}{l}\text { Swain's Bay, Observatory } \\
\text { Bay }\end{array}$ \\
\hline Palmaria georgica & (Reinsch) R.W. Ricker & Imata L. & - \\
\hline Paraglossum crassinervium & $\begin{array}{l}\text { (Montagne) S.-M.Lin, Fredericq \& } \\
\text { Hommersand }\end{array}$ & Delesseria crassinervia Mont. & Swain's Bay \\
\hline Phycodrys quercifolia & (Bory de Saint-Vincent) Skottsberg & Delesseria quercifolia Bory & Swain's Bay \\
\hline Platyclinia fuscorubra & (J.D.Hooker \& Harvey) Levring & $\begin{array}{l}\text { Nitophyllum fusco-rubrum H. f. \& } \\
\text { Harv. }\end{array}$ & Swain's Bay \\
\hline Plocamium hookeri & Harvey & Plocamium hookeri Har. & Swain's Bay \\
\hline Plumariopsis eatonii & (Dickie) De & Ptilota eatoni n.sp. & Swain's Bay \\
\hline Polysiphonia abscissa & J.D.Hooker \& Harvey & Polysiphonia abscissa H. f. \& Harv. & Swain's Bay \\
\hline Pterothamnion simile & (J.D.Hooker \& Harvey) Nägeli & Callithamnion simile H. f. \& Harv. & Swain's Bay \\
\hline Ptilonia magellanica & (Montagne) J.Agardh & Ptilonia magellanica Mont. & \\
\hline Rhodochorton purpureum & (Lightfoot) Rosenvinge & Callithamnion rothii Lyngb. & Observatory Bay \\
\hline Rhodoglossum gigartinoides & (Sonder) Edyvane \& Womersley & Halymenia latissima H. f. \& Harv. & $\begin{array}{l}\text { Swain's Bay, Observatory } \\
\text { Bay }\end{array}$ \\
\hline Rhodophyllis reptans & (Suhr) Papenfuss & Rhodophyllis capensis Ktz. & Observatory Bay \\
\hline Rhodymenia coccocarpa & (Montagne) M.J.Wynne & Phyllophora cuneifolia H. f. \& Harv. & Swain's Bay \\
\hline Rhodymenia variolosa & J.D.Hooker \& Harvey & Epymenia variolosa H. f. \& Harv. & Swain's Bay \\
\hline Sarcodia dentata & (Suhr) R.E.Norris & Kallymenia dentata Suhr. Var a. & - \\
\hline Sarcothalia radula & (Esper) Edyvane \& Womersley & Gigartina radula Esp. & Swain's Bay \\
\hline Schizoseris griffithsia & (Suhr) M.J.Wynne & Delesseria davisii H. f. \& Harv. & Observatory Bay \\
\hline
\end{tabular}


APPENDIX 4. - Macroalgae collected during the US Venus transit expedition (Farlow 1876). No sampling sites were mentioned but specimens were likely collected in the Royal Sound (presently Baie du Morbihan) in the Observatory Bay and near Pointe Molloy. (Fig. 2).

\begin{tabular}{|c|c|c|}
\hline \multicolumn{2}{|l|}{ accepted name } & reported as \\
\hline CHLOROPHYTA & & - \\
\hline Codium adhaerens & C.Agardh & Codium adhaerens, Ag. \\
\hline Uncertain status & - & Ulva latissima \\
\hline OCHROPHYTA-Phaeophyceae & & s \\
\hline Adenocystis utricularis & (Bory de Saint-Vincent) Skottsberg & Adenocystis lessonii, H. \& H. \\
\hline Desmarestia viridis & (O.F.Müller) J.V.Lamouroux & Desmarestia viridis Lam. \\
\hline Durvillaea antarctica & (Chamisso) Hariot & D’Urvillea viridis, Bory / D’Urvillea harveyi, Hook. \\
\hline Halopteris funicularis & (Montagne) Sauvageau & Sphacellaria funicularis, Mont. \\
\hline Macrocystis pyrifera & (Linnaeus) C.Agardh & Macrocystis pyrifera, Ag. \\
\hline RHODOPHYTA & & - \\
\hline Ballia callitricha & (C.Agardh) Kützing & Ballia callitricha, Ag. \\
\hline Callophyllis variegata & (Bory de Saint-Vincent) Kützing & Callophyllis variegata, Ag. \\
\hline Ceramium & (Lyngbye) C.Agardh & Ceramium rubrum var. secundatum, Lyngb. \\
\hline Cladodonta rubrum var. secundatum & (J.D.Hooker \& Harvey) Skottsberg & Delesseria lyallii, H. \& H. \\
\hline Dasyptilon lyallii & (J.D.Hooker \& Harvey) Athanasiadis & Callithamnion ptilota, H. \& H. \\
\hline Heterosiphonia ptilota & Montagne & Dasya (Polysiphonia, H. \& H.) bekerleyi, Ag. \\
\hline Lophurella gaimardii & (Gaudichaud ex C.Agardh) De Toni & Rhodomela gaimardii, Mont. \\
\hline Myriogramme livida & (J.D.Hooker \& Harvey) Kylin & Nitophyllum lividum, H. \& H. \\
\hline Palmaria georgica & (Reinsch) R.W. Ricke & Rhodymenia palmata, Grev. \\
\hline Platyclinia fuscorubra & (J.D.Hooker \& Harvey) Levring & Nitophyllum fusco-rubrum, H. \& H. \\
\hline Ptilonia magellanica & (Montagne) J.Agardh & Ptilonia magellanica, Ag. \\
\hline Rhodymenia corallina & (Bory de Saint-Vincent) Greville & Rhodymenia corallina, Grev. \\
\hline Rhodymenia variolosa & J.D.Hooker \& Harvey & Rhodymenia variolosa, H. \& H. \\
\hline Sarcothalia radula & (Esper) Edyvane \& Womersley & Gigartina radula, Ag. \\
\hline
\end{tabular}

APPENDIX 5. - Dickie (1879) published a new list of the macroalgae from the Kerguelen Islands, compiling Moseley's (Challenger expedition 1873-74), Hooker's (Ross expedition 1840) and Farlow's (US Venus transit expedition 1874-75) datasets and improving the number of collection sites by addition of Baie de l'Oiseau (Christmas Harbour) (Fig. 2)

\begin{tabular}{|c|c|c|c|}
\hline \multicolumn{2}{|l|}{ accepted name } & reported as & collection sites \\
\hline CHLOROPHYTA & & - & - \\
\hline Acrosiphonia arcta & (Dillwyn) Gain & Cladophora arcta Ktz. & Observatory Bay, Royal Sound \\
\hline Bryopsis plumosa & (Hudson) C.Agardh & Bryopsis plumosa Grev. & Observatory Bay \\
\hline Cladophora flexuosa & (O.F.Müller) Kützing & Cladophora flexuosa Griff. & Observatory Bay, Swain's Bay \\
\hline Cladophora rupestris & (Linnaeus) Kützing & Cladophora rupertris Linnn. & Christmas Harbour \\
\hline Cladophora subsimplex & Kützing & $\begin{array}{l}\text { Cladophora simpliciuscula H. f. \& } \\
\text { Harv. }\end{array}$ & Observatory Bay \\
\hline Codium adhaerens & C.Agardh & Codium adhaerens Ag. & Swain's Bay \\
\hline Codium tomentosum & Stackhouse & Codium tomentosum Stackh. & Christmas Harbour \\
\hline Prasiola cristata & (J.D.Hooker \& Harvey) J.Agardh & Ulva? cristata Hook. F. \& Harv. & Christmas Harbour \\
\hline Rhizoclonium ambiguum & (J.D.Hooker \& Harvey) Kützing & Rhizoclinum ambiguum Kütz. & Christmas Harbour \\
\hline Rhizoclonium riparium & (Roth) Harvey & Rhizoclinum riparium Roth. & Christmas Harbour \\
\hline Ulva compressa & Linneaus & Enteromorpha compressa Link & $\begin{array}{l}\text { Christmas Harbour, Royal Sound, } \\
\text { Swain's Bay }\end{array}$ \\
\hline Ulva intestinalis & Linneaus & Enteromorpha intestinalis Linn. & Christmas Harbour \\
\hline OCHROPHYTA-Phaeophyce & & - & - \\
\hline Colpomenia sinuosa & (Mertens ex Roth) Derbès \& Solier & Asperococcus sunuosus Roth. & Royal Sound intertidal, Observatory Bay \\
\hline Desmarestia chordalis & J.D.Hooker \& Harvey & Desmarestia chordalis H.f. \& Harv. & Swain's Bay, Christmas Harbour \\
\hline Desmarestia menziessi & J.Agardh & $\begin{array}{l}\text { Desmarestias aculeata var. media } \\
\text { Grev. }\end{array}$ & Swain's Bay \\
\hline Desmarestia rossi & J.D.Hooker \& Harvey & Desmarestia rossi H.f. \& Harv. & Swain's Bay 3 fathoms \\
\hline Desmarestia viridis & (O.F.Müller) J.V.Lamouroux & Desmarestia viridis Grev. & $\begin{array}{l}\text { Observatory Bay, Christmas Harbour, } \\
\text { Royal Sound, Swain's Bay }\end{array}$ \\
\hline Durvillaea antarctica & (Chamisso) Hariot & $\begin{array}{l}\text { D'urvillea utilis, Bory / D'urvillea } \\
\text { harveyi }\end{array}$ & - \\
\hline Elachista flaccida & (Dillwyn) Fries & Elachista flaccida Aresch & Observatory Bay \\
\hline Geminocarpus geminatus & (J.D.Hooker \& Harvey) Skottsberg & Ectocarpus geminatus H. f. \& Harv. & $\begin{array}{l}\text { Observatory Bay, Christmas Harbour, } \\
\text { Swain's Bay }\end{array}$ \\
\hline Halopteris corymbosa & $\begin{array}{l}\text { (Dickie) Draisma, Prud'homme \& } \\
\text { H.Kawai }\end{array}$ & Sphacelaria corymbosa n.sp. & Pointe Molloy \\
\hline
\end{tabular}




\begin{tabular}{|c|c|c|c|}
\hline \multicolumn{2}{|l|}{ accepted name } & reported as & collection sites \\
\hline Lessonia flavicans & Bory de Saint-Vincent & Lessonia fuscescens Bory & - \\
\hline Macrocystis pyrifera & (Linnaeus) C.Agardh & Macrocystis pyrifera Ag. & - \\
\hline Scytosiphon lomentaria & (Lyngbye) Link & Scytosiphon lomentarium Grev. ? & Christmas Harbour \\
\hline Sphacelaria affinis & Dickie & Sphacelaria affinis & Swain's Bay \\
\hline RHODOPHYTA & & - & 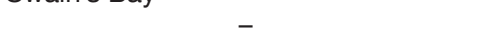 \\
\hline Ahnfeltia plicata & (Hudson) E.M.Fries & Ahnfeltia plicata Huds. & $\begin{array}{l}\text { Observatory Bay intertidal lower, } \\
\text { Christmas Harbour }\end{array}$ \\
\hline Ballia callitricha & (C.Agardh) Kützing & Ballia callitricha Ag. & $\begin{array}{l}\text { Observatory Bay, Swain's Bay, } \\
\text { Christmas Harbour }\end{array}$ \\
\hline Bostrychia vaga & J.D.Hooker \& Harvey & Bostrychia vaga Hook. F. \& Harv. & Christmas Harbour \\
\hline Callophyllis tenera & J.Agardh & Calophyllis tenera J. Ag. & Swain's Bay \\
\hline Callophyllis variegata & (Bory de Saint-Vincent) Kützing & Calophyllis variegata Bory & $\begin{array}{l}\text { Swain's Bay, Christmas Harbour, } \\
\text { Royal Sound }\end{array}$ \\
\hline Carlskottsbergia antarctica & (J.D.Hooker \& Harvey) Athanasiadis & sMelobesia antarctica H. f. \& Harv. & Swain's Bay, Christmas Harbour \\
\hline - & & Melobesia lichenoides Ell. \& Sol. & Swain's Bay \\
\hline Ceramium virgatum & Roth & Ceramium rubrum Ag. & Swain's Bay, Christmas Harbour \\
\hline Cladodonta lyallii & (J.D.Hooker \& Harvey) Skottsberg & Delesseria lyallii H. f. \& Harv. & $\begin{array}{l}\text { Observatory Bay + Swain's Bay, } \\
\text { Christmas Harbour }\end{array}$ \\
\hline Dasyptilon ptilota & (J.D.Hooker \& Harvey) Athanasiadis & sCallithamnion ptilota H. \& H. & Royal Sound \\
\hline Delisea pulchra & (Greville) Montagne & Delisea pulchra Mont. & $\begin{array}{l}\text { Christmas Harbour, Swain's Bay, } \\
\text { Royal Sound }\end{array}$ \\
\hline Erythroglossum laciniatum & (Lightfoot) Maggs \& Hommersand & Porphyra laciniata Ag. & Observatory Bay, Christmas Harbour \\
\hline Heterosiphonia berkeleyi & Montagne & Dasya berkeleyi Mont. & Swain's Bay, Royal Sound \\
\hline Hymenena laciniata & (J.D.Hooker \& Harvey) Kylin & $\begin{array}{l}\text { Nitophyllum laciniatum H. f. \& } \\
\text { Harv. }\end{array}$ & Swain's Bay \\
\hline Lithothamnion kerguelenum & ?(Dickie) Foslie & Melobesia kerguelena n.sp. & Swain's Bay \\
\hline Lophurella hookeriana & (J.Agardh) Falkenberg & Rhodomela hookeriana J. Ag. & $\begin{array}{l}\text { Swain's Bay, Observatory Bay, Pointe } \\
\text { Molloy }\end{array}$ \\
\hline Mazzaella capensis & (J.Agardh) Fredericq & Iridaea capensis J.Ag. & - \\
\hline Mazzaella laminarioides & (Bory de Saint-Vincent) Fredericq & Iridea laminaroides Bory & - \\
\hline Myriogramme livida & (J.D.Hooker \& Harvey) Kylin, 1924 & Nitophyllum lividum H. f. \& Harv. & Swain's Bay, Royal Sound \\
\hline Nothogenia fastigiata & $\begin{array}{l}\text { (Bory de Saint-Vincent) } \\
\text { P.G.Parkinson }\end{array}$ & Chaetangium variolosum Mont. & $\begin{array}{l}\text { Observatory Bay, Christmas Harbour, } \\
\text { Swain's Bay }\end{array}$ \\
\hline Paraglossum crassinervium & $\begin{array}{l}\text { (Montagne) S.-M.Lin, Frederica \& } \\
\text { Hommersand }\end{array}$ & Delesseria crassinervia Mont. & Swain's Bay, Observatory Bay \\
\hline Phycodrys quercifolia & (Bory de Saint-Vincent) Skottsberg & Delesseria quercifolia Bory & Swain's Bay \\
\hline Platyclinia fuscorubra & (J.D.Hooker \& Harvey) Levring & $\begin{array}{l}\text { Nitophyllum fusco-rubrum H. f. \& } \\
\text { Harv. }\end{array}$ & Swain's Bay, Christmas Harbour \\
\hline Plocamium hookeri & Harvey & Plocamium hookeri Har. & Swain's Bay, Christmas Harbour \\
\hline Plumariopsis eatonii & (Dickie) De Toni & Ptilota eatoni Dickie & Swain's Bay \\
\hline Polysiphonia abscissa & J.D.Hooker \& Harvey & Polysiphonia abscissa H. f. \& Harv. & Observatory Bay \\
\hline Polysiphonia anisogona & J.D.Hooker \& Harvey & $\begin{array}{l}\text { Polysiphonia anisogona HooK. F. \& } \\
\text { Harv. }\end{array}$ & (n) \\
\hline Porphyra purpurea & (Roth) C.Agardh & Porphyra vulgaris Ag. & Christmas Harbour \\
\hline Pterothamnion simile & (J.D.Hooker \& Harvey) Nägeli & Callithamnion simile H. f. \& Harv. & $\begin{array}{l}\text { Christmas Harbour, Swain's Bay, } \\
\text { Observatory Bay }\end{array}$ \\
\hline Ptilonia magellanica & (Montagne) J.Agardh & Ptilonia magellanica Mont. & Swain's Bay \\
\hline Rhodochorton purpureum & (Lightfoot) Rosenvinge & Callithamnion rothii Lyngb. & Observatory Bay, Swain's Bay \\
\hline $\begin{array}{l}\text { Rhodoglossum } \\
\text { gigartinoides }\end{array}$ & (Sonder) Edyvane \& Womersley & Halymenia latissima H. f. \& Harv. & Observatory Bay, Swain's Bay \\
\hline Rhodophyllis reptans & (Suhr) Papenfuss & Rhodophyllis capensis Ktz. & Swain's Bay \\
\hline Rhodymenia coccocarpa & (Montagne) M.J.Wynne & Phyllophora cuneifolia H. f. \& Harv. & Swain's Bay, Christmas Harbour \\
\hline Rhodymenia corallina & (Bory de Saint-Vincent) Greville & Rhodymenia corallina Grev. & Christmas Harbour \\
\hline Rhodymenia dichotoma & J.D.Hooker \& Harvey & Callophyllis dichotoma Kütz. & Swain's Bay \\
\hline Rhodymenia variolosa & J.D.Hooker \& Harvey & Epymenia variolosa H. f. \& Harv. & $\begin{array}{l}\text { Swain's Bay, Christmas Harbour, } \\
\text { Royal Sound }\end{array}$ \\
\hline Sarcodia dentata & (Suhr) R.E.Norris & Kallymenia dentata Suhr. Var a. & Swain's Bay \\
\hline Sarcothalia radula & (Esper) Edyvane \& Womersley & Gigartina radula Esp. & $\begin{array}{l}\text { Swain's + Observatory Bays, } \\
\text { Christmas Harbour }\end{array}$ \\
\hline Schizoseris dichotoma & (J.D.Hooker \& Harvey) Kylin & $\begin{array}{l}\text { Nitophyllum multinerve Hook. f. \& } \\
\text { Harv. }\end{array}$ & Christmas Harbour \\
\hline Schizoseris griffithsia & (Suhr) M.J.Wynne & Delesseria davisii H. f. \& Harv. & Swain's Bay \\
\hline
\end{tabular}


APPENDIX 6. - Askenasy (1889) published the report on the macroalgae collected during the German Venus transit expedition (1874-75). The Gazelle was anchored in the Baie Accessible, north coast of Péninsule Courbet (Fig. 2). Most samples were taken in Betsy Cove.

\begin{tabular}{|c|c|c|c|}
\hline \multicolumn{2}{|l|}{ accepted name } & reported as & collection sites \\
\hline CHLOROPHYTA & & - & - \\
\hline Acrosiphonia arcta & (Dillwyn) Gain & $\begin{array}{l}\text { Cladophora (Spongomorpha) arcta } \\
\text { (Dillw.) Kütz. }\end{array}$ & Betsy Cove \\
\hline Cladophora aegiceras & (Montagne) Kützing & $\begin{array}{l}\text { Cladomorpha (Spongomorpha) aegiceras } \\
\text { (Mont.) Kütz. }\end{array}$ & Betsy Cove \\
\hline Codium effusum & (Rafinesque) Delle Chiaje & Codium difforme Kützing & Betsy Cove \\
\hline Uncertain status & - & Ulva lactuca (L.) Le Jolis, var. latissima & - \\
\hline \multicolumn{2}{|c|}{ OCHROPHYTA-Phaeophyceae } & - & - \\
\hline Chordariopsis capensis & (C.Agardh) Kylin & Chordaria capensis Kütz. & Betsy Cove \\
\hline Desmarestia rossii & J.D.Hooker \& Harvey & Desmarestia rossii Hook. f. \& Harv. & Betsy Cove \\
\hline Desmarestia viridis & (O.F.Müller) J.V.Lamouroux & Desmarestia viridis Lamour. & Betsy Cove \\
\hline Ectocarpus constanciae & Hariot & Ectocarpus constanciae Hariot & - \\
\hline Ectocarpus fasciculatus & Harvey & Ectocarpus fasciculatus & - \\
\hline Geminocarpus geminatus & (J.D.Hooker \& Harvey) Skottsberg & Ectocarpus geminatus Hook. f. et Harvey & Betsy Cove \\
\hline Halopteris funicularis & (Montagne) Sauvageau & Sphacelaria funicularis Mont. & - \\
\hline Macrocystis pyrifera & (Linnaeus) C.Agardh & Macrocystis pyrifera Agardh & Betsy Cove \\
\hline RHODOPHYTA & & - & - \\
\hline Ahnfeltiopsis concinna & (J.Agardh) P.C.Silva \& DeCew & Ahnfeltia concinna J. Ag. & Betsy Cove \\
\hline Ballia callitricha & (C.Agardh) Kützing & Ballia callitricha (Ag.) Montagne & Betsy Cove \\
\hline Callophyllis atrosanguinea & (J.D.Hooker \& Harvey) Hariot & $\begin{array}{l}\text { Callophyllis variegata var. atrosanguinea } \\
\text { Hook. F. et Harvey }\end{array}$ & Cascade Bay \\
\hline Callophyllis variegata & (Bory de Saint-Vincent) Kützing & Callophyllis variegata (Bory) Kützing & Betsy Cove \\
\hline Carlskottsbergia antarctica & (J.D.Hooker \& Harvey) Athanasiadis & Melobesia antarctica Hooker f. et Harvey & - \\
\hline Ceramium virgatum & Roth & Ceramium rubrum (Huds.) C. Ag. & Betsy Cove, Cascade Bay \\
\hline Cladodonta lyallii & (J.D.Hooker \& Harvey) Skottsberg & Delesseria lyallii Hooker f. et Harvey & Betsy Cove \\
\hline Delisea pulchra & (Greville) Montagne & Delisea pulchra (Grev.) Montagne & Betsy Cove \\
\hline Griffithsia antarctica & J.D.Hooker \& Harvey & Griffithsia antarctica Hook. f. et Harv. & - \\
\hline Haraldiophyllum crispatum & $\begin{array}{l}\text { (J.D.Hooker \& Harvey) S.M.Lin, } \\
\text { Hommersand \& W.A.Nelson }\end{array}$ & $\begin{array}{l}\text { Nitophyllum crispatum Hooker f. et } \\
\text { Harvey }\end{array}$ & Betsy Cove \\
\hline Heterosiphonia berkeleyi & Montagne & Dasya bekerleyi (Mont.) J. Ag. & Betsy Cove \\
\hline Hildenbrandia kerguelensis & (Askenasy) Y.M.Chamberlain & $\begin{array}{l}\text { Hildenbranchia prototypus var. } \\
\text { kerguelensis }\end{array}$ & - \\
\hline Lophurella patula & (J.D.Hooker \& Harvey) De Toni & Rhodomela patula Hooker f. et Harvey & - \\
\hline Myriogramme livida & (J.D.Hooker \& Harvey) Kylin & Nitophyllum lividum Hooker f. et Harvey & - \\
\hline Myriogramme smithii & (J.D.Hooker \& Harvey) Kylin & Nitophyllum smithii Hooker f. et Harvey & Betsy Cove \\
\hline Nothogenia fastigiata & (Bory de Saint-Vincent) P.G.Parkinson & Chaetangium variolosum (Mont.) J. Ag. & - \\
\hline Palmaria georgica & (Reinsch) R.W. Ricke & Rhodymenia palmata (L.) Grev. & - \\
\hline Phycodrys quercifolia & (Bory de Saint-Vincent) Skottsberg & Delesseria quercifolia Bory & Successful Harbour \\
\hline Phymatolithon calcareum & $\begin{array}{l}\text { (Pallas) W.H.Adey \& D.L.McKibbin ex } \\
\text { Woelkering \& L.M.Irvine }\end{array}$ & Lithothamnion polymorphum (L.) Aresch. & - \\
\hline Plocamium hookeri & Harvey & Plocanium hookeri Hooker f. et Harvey & - \\
\hline Plocamium secundatum & (Kützing) Kützing & Plocanium secundatum Kützing & Successful Harbour \\
\hline Plumariopsis eatonii & (Dickie) De Toni & Ptilota eatoni Dickie & - \\
\hline Polysiphonia abscissa & J.D.Hooker \& Harvey & Polysiphonia abscissa Hook. f. et Harv. & Betsy Cove \\
\hline Polysiphonia anisogona & J.D.Hooker \& Harvey & $\begin{array}{l}\text { Polysiphonia anisogona Hooker f. et } \\
\text { Harvey }\end{array}$ & Betsy Cove \\
\hline $\begin{array}{l}\text { Pseudophycodrys } \\
\text { phyllophora }\end{array}$ & (J.Agardh) Skottsberg & Delesseria phyllophora J. Ag. & Betsy Cove, Cascade Bay \\
\hline Pterothamnion simile & (J.D.Hooker \& Harvey) Nägeli & Callithamnion simile Hook. f. et Harvey & - \\
\hline Ptilonia magellanica & (Montagne) J.Agardh & Ptilonia magellanica & $\begin{array}{r}\text { Betsy Cove, Cascade Bay, } \\
\text { Harbour Island, Irish Bay }\end{array}$ \\
\hline Rhodophyllis reptans & (Suhr) Papenfuss & Rhodophyllis capensis Kütz. & Betsy Cove \\
\hline Rhodymenia coccocarpa & (Montagne) M.J.Wynne & Phyllophora cuneifolia Hook. f. et Harvey & - \\
\hline Rhodymenia corallina & (Bory de Saint-Vincent) Greville & Rhodymenia corallina (Bory) Grev. & - \\
\hline Rhodymenia obtusa & (Greville) Womersley & Epymenia obtusa (Grev.) Kützing & Betsy Cove \\
\hline Rhodymenia variolosa & J.D.Hooker \& Harvey & $\begin{array}{l}\text { Epymenia variolosa (Hook. f. et Harvey) } \\
\text { Kütz. }\end{array}$ & Betsy Cove \\
\hline Sarcothalia radula & (Esper) Edyvane \& Womersley & Gigartina radula (Esp.) J. Ag. & Betsy Cove \\
\hline Schizoseris dichotoma & (J.D.Hooker \& Harvey) Kylin & Delesseria pleurospora Harvey & Betsy Cove \\
\hline Schizoseris dichotoma & (J.D.Hooker \& Harvey) Kylin & Delesseria dichotome Hooker f. et Harvey & yCascade Bay \\
\hline- & - & $\begin{array}{l}\text { Nitophyllum mutinerve Hooker f. et } \\
\text { Harvey }\end{array}$ & Cascade Bay \\
\hline Schizoseris griffithsia & (Suhr) M.J.Wynne & Delesseria diavisii Hooker f. et Harvey & Betsy Cove \\
\hline
\end{tabular}


APPENDIX 7. - The macroalgae collected during the first German South Polar expedition in 1901-03 (Observatory Bay) were identified by Reinbold (1908) and Foslie (1908).

\begin{tabular}{|c|c|c|c|}
\hline accepted name & & reported as & Collection sites \\
\hline Reinbold (1908) & & & \\
\hline CHLOROPHYTA & & - & - \\
\hline Prasiola crispa & (Lightfoot) Kützing & Prasiola crispa (Lightf.) Ag. & - \\
\hline Codium effusum & (Rafinesque) Delle Chiaje & Codium difforme Kg. & - \\
\hline Cladophora incompta & $\begin{array}{l}\text { (J.D.Hooker \& Harvey) J.D.Hooker \& } \\
\text { Harvey }\end{array}$ & $\begin{array}{l}\text { Cladophora incompta Hook. f. et Harv. } \\
\text { F. tenuis n.f. }\end{array}$ & - \\
\hline Cladophora subsimplex & Kützing & Cladophora subsimplex Kg. & - \\
\hline Acrosiphonia arcta & (Dillwyn) Gain & Cladophora arcta (Dillw.) Kg. & - \\
\hline Spongomorpha pacifica & (Montagne) Kützing & $\begin{array}{l}\text { Cladophora (Spongomorpha) pacifica } \\
\text { (Mont.) Kg. }\end{array}$ & - \\
\hline Urospora penicilliformis & (Roth) Areschoug & Urospora penicilliformis (Roth) Aresch. & - \\
\hline- & 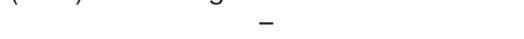 & Codiolum gregarium A. Br. & - \\
\hline Ulva compressa & Linneaus & Enteromorpha compressa (L.) Grev. & - \\
\hline Ulva hookeriana & $\begin{array}{l}\text { (Kützing) Hayden, Blomster, Maggs, } \\
\text { P.C.Silva, M.J.Stanhope \& J.R.Waaland }\end{array}$ & Enteromorpha bulbosa (Suhr) Kg. & - \\
\hline Ulva lactuca & Linneaus & Ulva lactuca (L.) Le Jol. & - \\
\hline- & - & Monostroma lactuca (L.) J. Agh. & - \\
\hline OCHROPHYTA-Phaeophyce & & - & - \\
\hline Desmarestia confervoides & $\begin{array}{c}\text { (Bory de Saint-Vincent) M.E.Ramírez \& } \\
\text { A.F.Peters }\end{array}$ & Desmarestia willii Reinsch. & - \\
\hline Geminocarpus geminatus & (J.D.Hooker \& Harvey) Skottsberg & $\begin{array}{l}\text { Geminocarpus geminatus (Hook. f. \& } \\
\text { Harv.) Skottsb. }\end{array}$ & - \\
\hline Adenocystis utricularis & (Bory de Saint-Vincent) Skottsberg & Adenocystis utricalis (Bory) Skottsb. & - \\
\hline Caepidium antarcticum & J.Agardh & Caepidium antarcticum J. Ag. & - \\
\hline Utriculidium durvillei & Skottsberg & $\begin{array}{l}\text { Utriculidium durvillei (Bory) Hook. f. \& } \\
\text { Harv.) Skottsb. }\end{array}$ & - \\
\hline Durvillaea antarctica & (Chamisso) Hariot & Durvillea utilis Bory & - \\
\hline Macrocystis pyrifera & (Linnaeus) C.Agardh & Macrocystis pyrifera (Turn.) Ag. & - \\
\hline Scytothamnus fasciculatus & (J.D.Hooker \& Harvey) A.D.Cotton & Dictyosiphon fasciculatus Hook. \& Harv. & - \\
\hline Halopteris corymbosa & (Dickie) Draisma, Prud'homme \& H.Kawai & iAlethocladus corymbosus (Dick.) Sauv. & - \\
\hline RHODOPHYTA & & - & - \\
\hline Acanthococcus antarcticus & J.D.Hooker \& Harvey & Acanthococcus antarcticus Hook. \& Harv. & - \\
\hline Ballia callitricha & (C.Agardh) Kützing & Ballia callitricha (Ag.) Mont. & - \\
\hline Callophyllis angustifrons & (Harvey) G.R.South \& N.M.Adams & Rhodophyllis angustifrons Hook. \& Harv. & - \\
\hline Callophyllis tenera & J.Agardh & Callophyllis tenera J. Ag. & - \\
\hline Callophyllis variegata & (Bory de Saint-Vincent) Kützing & Callophyllis variegata (Bory) $\mathrm{Kg}$. & - \\
\hline Ceramium virgatum & Roth & Ceramium rubrum (Huds.) Ag. & - \\
\hline Cladodonta Iyallii & (J.D.Hooker \& Harvey) Skottsberg & Delesseria lyallii Hook.\& Harv. & - \\
\hline Erythroglossum laciniatum & (Lightfoot) Maggs \& Hommersand & Porphyra laciniata (Lightf.) Ag. & - \\
\hline Heterosiphonia berkeleyi & Montagne & Heterosiphonia bekerleyi Mont. & - \\
\hline Lophurella hookeriana & (J.Agardh) Falkenberg & Lophorella hookeriana (J. Ag.) Falkbg. & - \\
\hline Nothogenia fastigiata & (Bory de Saint-Vincent) P.G.Parkinson & Chaetangium variolosum (Mont.) J. Ag. & - \\
\hline Palmaria georgica & (Reinsch) R.W. Ricke & Rhodymenia palmata (L.) Grev. & - \\
\hline Paraglossum crassinervium & $\begin{array}{c}\text { (Montagne) S.-M.Lin, Fredericq \& } \\
\text { Hommersand }\end{array}$ & $\begin{array}{l}\text { Delesseria (Hypoglossum) crassinervia } \\
\text { Kg. }\end{array}$ & - \\
\hline Polysiphonia abscissa & J.D.Hooker \& Harvey & Polysiphonia abscissa Hook. \& Harv. & - \\
\hline Ptilonia magellanica & (Montagne) J.Agardh & Ptilonia magellanica (Mont.) J. Ag. & - \\
\hline Rhodymenia capensis & J.Agardh & Rhodymenia capensis J. Ag. ? & - \\
\hline Rhodymenia variolosa & J.D.Hooker \& Harvey & Epymenia variolosa (Hook. \& Harv.) Kg. & - \\
\hline Sarcodia palmata & Sonder & Sarcodia palmata Sond? & - \\
\hline Sarcothalia radula & (Esper) Edyvane \& Womersley & Gigartina radula (Esp.) J. Ag. & - \\
\hline Schizoseris dichotoma & (J.D.Hooker \& Harvey) Kylin & Delesseria pleurospora J. Ag. & - \\
\hline- & - & Nitophyllum multinerre Hook. \& Harv. & - \\
\hline Foslie (1908) & & & - \\
\hline RHODOPHYTA & & & - \\
\hline Clathromorphum obtectulim & (Foslie) Adey & Lithothamnion obtectulum Foslie & Royal Sound \\
\hline Lithothamnion kerguelenum & (Dickie) Foslie & Lithothamnion kerguelenum Dickie & Swain's Bay \\
\hline Phymatolithon lenormandii & (Areschoug) W.H. Adey & Lithothamnion annulatum Foslie & Betsy Cove \\
\hline Spongites discoideus & (Foslie) D.Penrose \& Woelkerling & Lithophyllum consociatum Foslie & $\begin{array}{l}\text { Royal Sound, Observatory } \\
\text { Bay, Betsy Cove }\end{array}$ \\
\hline- & - & $\begin{array}{l}\text { Lithophyllum consociatum f. connata } \\
\text { Foslie }\end{array}$ & - \\
\hline- & - & $\begin{array}{l}\text { Lithophyllum consociatum f. typica } \\
\text { Foslie }\end{array}$ & - \\
\hline Synarthrophyton neglectum & (Foslie) M.L. Mendoza & Lithothamnion neglectum Foslie & $\begin{array}{l}\text { Swain's Bay, Royal Sound, } \\
\text { Observatory Bay }\end{array}$ \\
\hline- & - & Lithothamnion neglectum f. fragilis Foslie & - \\
\hline- & - & Lithothamnion neglectum f. typica Foslie & - \\
\hline
\end{tabular}


APPENDIX 8. - Gain (1912) published a compiled list of macroalgae based on Hooker's reports on the Venus Transit and Challenger expeditions.

\begin{tabular}{|c|c|c|}
\hline \multicolumn{2}{|l|}{ accepted name } & reported as \\
\hline CHLOROPHYTA & - & - \\
\hline Acrosiphonia arcta & (Dillwyn) Gain & Acrosiphonia arcta (Dillw.) J.Arg. \\
\hline Bryopsis plumosa & (Hudson) C.Agardh & Bryopsis plumosa Ag. \\
\hline Chaetomorpha litorea & Harvey & Chaetomorpha littorea Harv. \\
\hline Cladophora aegiceras & (Montagne) Kützing & Cladophora aegiceras (Mont.) Kg. \\
\hline Cladophora flexuosa & (O.F.Müller) Kützing & Cladophora flexuosa Hook. \& Harv. \\
\hline Cladophora incompta & (J.D.Hooker \& Harvey) J.D.Hooker \& Harvey & Cladophora incompta Hook. F. \& Harv. \\
\hline Cladophora rupestris & (Linnaeus) Kützing & Cladophora rupestris Kg. \\
\hline Cladophora subsimplex & Kützing & Cladophora subsimplex Kg. \\
\hline Codium effusum & (Rafinesque) Delle Chiaje & Codium difforme $\mathrm{Kg}$ \\
\hline Codium tomentosum & Stackhouse, & Codium tomentosum Stackh. \\
\hline Rhizoclonium ambiguum & (J.D.Hooker \& Harvey) Kützing & Rhizoclonium ambiguum $\mathrm{Kg}$. \\
\hline Rhizoclonium riparium & (Roth) Harvey & Rhizoclonium riparium (Roth) Aresch. \\
\hline- & (1) & Cladophora riparia (Roth) \\
\hline Spongomorpha pacifica & (Montagne) Kützing & Cladophora pacifica (Mont.) Kg. \\
\hline Ulva compressa & Linneaus & Enteromorpha compressa Grev \\
\hline Ulva hookeriana & $\begin{array}{l}\text { (Kützing) Hayden, Blomster, Maggs, P.C.Silva, } \\
\text { M.J.Stanhope \& J.R.Waaland }\end{array}$ & Enteromorpha bulbosa (Suhr) Kg \\
\hline Ulva intestinalis & Linneaus & Enteromorpha intestinalis Link \\
\hline Ulva lactuca & Linneaus & Monostroma lactuca (L.) J.Ag. \\
\hline- & - & Ulva lactuca (L.) Le Jolis \\
\hline Urospora penicilliformis & (Roth) Areschoug & Urospora penicilliformis (Roth) \\
\hline- & 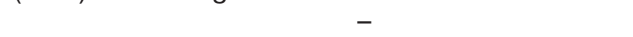 & Codiolum gregarium A.Braun \\
\hline \multicolumn{3}{|l|}{ OCHROPHYTA-Phaeophyceae } \\
\hline Adenocystis utricularis & (Bory de Saint-Vincent) Skottsberg & Adenocystis lessonii Hook. \& Harv. \\
\hline Caepidium antarcticum & J.Agardh & Caepidium antarcticum J.Ag. \\
\hline Chordariopsis capensis & (C.Agardh) Kylin & Chordaria capensis Kg. \\
\hline Colpomenia sinuosa & (Mertens ex Roth) Derbès \& Solier & Colpomenia sinuosa (Roth) Derb. \& Sol. \\
\hline Desmarestia chordalis & J.D.Hooker \& Harvey & Desmarestia chordalis Hook. f. \& Harv. \\
\hline Desmarestia confervoides & (Bory de Saint-Vincent) M.E.Ramírez \& A.F.Peters & Desmarestia willi Reinsch \\
\hline Desmarestia menziesii & J.Agardh & Desmarestia compressa (Reinsch) Skottsb. \\
\hline Desmarestia rossi & J.D.Hooker \& Harvey & Desmarestia rossii Hook. f. \& Harv. \\
\hline Durvillaea antarctica & (Chamisso) Hariot & Durvillea antarctica (Cham.) Hariot \\
\hline & Hariot & Durvillea harveyi Hook. f. \\
\hline $\begin{array}{l}\text { Ectocarpus constanclae } \\
\text { Elachista flaccida }\end{array}$ & $\begin{array}{l}\text { Hariot } \\
\text { (Dillwyn) Fries }\end{array}$ & $\begin{array}{l}\text { Ectocarpus constanciae Hariot } \\
\text { Elachistea flaccida Aresch. (?) }\end{array}$ \\
\hline Geminocarpus geminatus & (J.D.Hooker \& Harvey) Skottsberg & $\begin{array}{l}\text { Geminocarpus geminatus (Hook. f. \& Harv.) } \\
\text { Stottsb. }\end{array}$ \\
\hline Halopteris funicularis & (Montagne) Sauvageau & Halopteris funicularis (Mont.) Sauv. \\
\hline Lessonia flavicans & Bory de Saint-Vincent & Lessonia flavicans Bory \\
\hline Lessonia nigrescens & Bory de Saint-Vincent & Lessonia nigrescens Bory \\
\hline Macrocystis pyrifera & (Linnaeus) C.Agardh & Macrocystis pyrifera (L.) C.A. Ag. \\
\hline Scytosiphon lomentaria & (Lyngbye) Link & Scytosiphon lomentaria (Lyngb.) J. Ag. \\
\hline Scytothamnus fasciculatus & (J.D.Hooker \& Harvey) A.D.Cotton & Dictyosiphon fasciculatus Hook. \& Harv. \\
\hline Sphacelaria affinis & Dickie & Sphacelaria affinis Dickie \\
\hline Utriculidium durvillei & Skottsberg & $\begin{array}{l}\text { Utriculidium durvillei (Bory? Hook. \& Harv.) } \\
\text { Skottsb. }\end{array}$ \\
\hline \multicolumn{2}{|l|}{ RHODOPHYTA } & 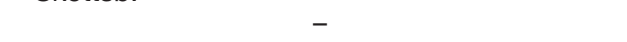 \\
\hline Acanthococcus antarcticus & J.D.Hooker \& Harvey & Acanthococcus antarcticus Hook. f. \& Harv. \\
\hline Ahnfeltia plicata & (Hudson) E.M.Fries & Ahnfeltia plicata Fries \\
\hline Ahnfeltiopsis concinna & (J.Agardh) P.C.Silva \& DeCew & Ahnfeltia concinna J. Ag. \\
\hline Ballia callitricha & (C.Agardh) Kützing & Ballia callitricha Mont. \\
\hline Bostrychia vaga & J.D.Hooker \& Harvey & Bostrychia vaga (Hook. f. \& Harv.) J. Ag. \\
\hline Callophyllis atrosanguinea & (J.D.Hooker \& Harvey) Hariot & Callophyllis atro sanguinea (Hook. \& Harv.) Hariot \\
\hline - & - & Rhodophyllis angustiformis Hook \& Harv. \\
\hline Callophyllis tenera & J.Agardh & Callophyllis tenera J. Ag. \\
\hline Callophyllis variegata & (Bory de Saint-Vincent) Kützing & Callophyllis variegata $\mathrm{Kg}$. \\
\hline Carlskottsbergia antarctica & (J.D.Hooker \& Harvey) Athanasiadis & Lithothamnion antarcticum (Hook. \& Harv.) Fosl. \\
\hline Ceramium diaphanum & (Lightfoot) Roth & Ceramium diaphanum Roth \\
\hline Ceramium virgatum & Roth & Ceramium rubrum Ag. \\
\hline Cladodonta lyallii & (J.D.Hooker \& Harvey) Skottsberg & Delesseria lyallii Hook. \& Harv. \\
\hline Clathromorphum obtectulum & (Foslie) Adey & Lithothamnion obtectulum Fosl. \\
\hline Dasyptilon ptilota & (J.D.Hooker \& Harvey) Athanasiadis & Antithamnion ptilota (Hook. \& Harv.) Neag. \\
\hline Delisea pulchra & (Greville) Montagne & Delisea pulchra (Mont.) Grev. \\
\hline Erythroglossum laciniatum & C.Agardh & Porphyra laciniata Ag. \\
\hline Griffithsia antarctica & J.D.Hooker \& Harvey & Bornelia antactica (Hook. \& Harv.) \\
\hline Haraldiophyllum crispatum & $\begin{array}{l}\text { (J.D.Hooker \& Harvey) S.M.Lin, Hommersand \& } \\
\text { W.A.Nelson }\end{array}$ & Nitophyllum crispatum Hook. f. \& Harv. \\
\hline $\begin{array}{l}\text { Heterosiphonia berkeleyi } \\
\text { Hildenbrandia rubra }\end{array}$ & $\begin{array}{l}\text { Montagne } \\
\text { (Sommerfelt) Meneghini }\end{array}$ & $\begin{array}{l}\text { Heterosiphonia berkleyi Mont. } \\
\text { Hildenbranchia prototypus Nardo }\end{array}$ \\
\hline
\end{tabular}


APPENDIX 8. - Continuation.

\begin{tabular}{|c|c|c|}
\hline \multicolumn{2}{|l|}{ accepted name } & \multirow{3}{*}{$\begin{array}{l}\text { reported as } \\
\text { Nitophyllum laciniatum Hook. f. \& Harv. } \\
\text { Iridaea cordata (Turner) J. ag. (?) }\end{array}$} \\
\hline Hymenena laciniata & (J.D.Hooker \& Harvey) Kylin & \\
\hline Iridaea cordata & (Turner) Bory de Saint-Vincent & \\
\hline Lithothamnion kerguelenum & (Dickie) Foslie & Lithothamnion kerguelenum (Dick.) Fosl. \\
\hline Lophurella hookeriana & (J.Agardh) Falkenberg & Lophurella hookeriana (J. Ag.) Schm. \\
\hline Lophurella patula & (J.D.Hooker \& Harvey) De Toni & Lophurella patula (Hook. \& Harv) Schm. \\
\hline Mazzaella laminarioides & (Bory de Saint-Vincent) Fredericg & Iridaea laminaroides Bory \\
\hline Myriogramme livida & (J.D.Hooker \& Harvey) Kylin & Nitophyllum grayanum J. Ag. \\
\hline- & - & Nitophyllum lividum Hook. f. \& Harv. \\
\hline Myriogramme smithii & (J.D.Hooker \& Harvey) Kylin & Nitophyllum smithii Hook. f. \& Harv. \\
\hline Nothogenia fastigiata & (Bory de Saint-Vincent) P.G.Parkinson & Chaetangium variolosum (Mont.) J .Ag. \\
\hline Palmaria georgica & (Reinsch) R.W. Ricke & Rhodymenia palmata Grev. \\
\hline Paraglossum epiglossum & (J.Agardh) J.Agardh & Delesseria epiglossum J. Ag. \\
\hline Phycodrys quercifolia & (Bory de Saint-Vincent) Skottsberg & Delesseria quercifolia Bory \\
\hline Phymatolithon lenormandii & (Areschoug) W.H.Adey & Lithothamnion lenormandii (Aresch.) Fosl. \\
\hline Platyclinia fuscorubra & (J.D.Hooker \& Harvey) Levring & Nitophyllum fusco-rubrum Hook. f. \& Harv. \\
\hline Plocamium hookeri & Harvey & Plocamium hookeri Harv. \\
\hline Plocamium secundatum & (Kützing) Kützing & Plocamium secundatum $\mathrm{Kg}$. \\
\hline Plumariopsis eatonii & (Dickie) De Toni & Ptilota eatoni Dickie \\
\hline Polysiphonia abscissa & J.D.Hooker \& Harvey & Polysiphonia abscissa Hook. \& Harv. \\
\hline Polysiphonia anisogona & J.D.Hooker \& Harvey & Polysiphonia anisogonia Hook. \& Harv. \\
\hline Porphyra umbilicalis & Kützing & Ulva umbilicalis L. \\
\hline Pseudophycodrys phyllophora & (J.Agardh) Skottsberg & Delesseria phyllophora J. Ag. \\
\hline Pterothamnion simile & (J.D.Hooker \& Harvey) Nägeli & Antithmnion simile (Hook. \& Harv.) J. Ag. \\
\hline Ptilonia magellanica & (Montagne) J.Agardh & Ptilonia magellanica J. Ag. \\
\hline Pyropia leucostica & (Thuret) Neefus \& J.Brodie & Porphyra leucosticta Thuret \\
\hline Rhodochorton purpureum & (Lightfoot) Rosenvinge & Rhodochorton rothii Lyngb. \\
\hline Rhodoglossum gigartinoides & (Sonder) Edyvane \& Womersley & Iridaea latissima (Hook. \& Harv.) Grun. \\
\hline Rhodophyllis reptans & (Suhr) Papenfuss & Rhodophyllis capensis $\mathrm{Kg}$. \\
\hline Rhodymenia capensis & J.Agardh & Rhodymena capensis Kg. \\
\hline Rhodymenia coccocarpa & (Montagne) M.J.Wynne & Phyllophora cuneifolia Hook. \& Harv. \\
\hline Rhodymenia corallina & (Bory de Saint-Vincent) Greville & Rhodymena corallina (Bory) Grev. \\
\hline Rhodymenia dichotoma & J.D.Hooker \& Harvey & Rhodymena? dichotoma Hook. \& Harv. \\
\hline Rhodymenia obtusa & (Greville) Womersley & Epymenia obtusa Kg. \\
\hline Rhodymenia variolosa & J.D.Hooker \& Harvey & Epymenia variolosa (Hook. \& Harv.) Kg. \\
\hline Sarcodia dentata & (Suhr) R.E.Norris & Callymenia dentata Suhr \\
\hline Sarcodia palmata & Sonder & Sarcodia palmata? Sond \\
\hline Sarcothalia radula & (Esper) Edyvane \& Womersley & Gigartina radula J. Ag. \\
\hline Schizoseris dichotoma & (J.D.Hooker \& Harvey) Kylin & Delesseria pleurospora Harv. \\
\hline Schizoseris dichotoma & (J.D.Hooker \& Harvey) Kylin & Delesseria dichotoma Hook. \& Harv. \\
\hline Schizoseris griffithsia & (Suhr) M.J.Wynne & Delesseria davisii Hook. \& Harv. \\
\hline Spongites discoideus & (Foslie) D.Penrose \& Woelkerling & Lithophyllum consociatum Fosl. \\
\hline Synarthrophyton neglectc & (Foslie) M.L.Mendoza & Lithothamnion neglectum Fosl. \\
\hline
\end{tabular}


APPENDIX 9. - Levring (1944) recorded macroalgae collected during the Solglimt expedition.

\begin{tabular}{|c|c|c|}
\hline \multicolumn{2}{|l|}{ accepted name } & reported as \\
\hline$\overline{\text { CHLOROPHYTA }}$ & & - \\
\hline Chaetomorpha kerguelensis & Levring & Chaetomorpha kerguelensis n.sp. \\
\hline Monostroma hariotii & Gain & Monostroma hariotii Gain \\
\hline Spongomorpha pacifica & (Montagne) Kützing & Acrosiphonia pacifica (Mont.) J. Ag. \\
\hline Ulva hookeriana & $\begin{array}{l}\text { (Kützing) Hayden, Blomster, Maggs, P.C.Silva, } \\
\text { M.J.Stanhope \& J.R.Waaland }\end{array}$ & Enteromorpha bulbosa (Suhr) Kütz \\
\hline Ulva & C.Agardh & Ulva rigida $\mathrm{C} . \mathrm{Ag}$. \\
\hline Ulvella viridis & (Reinke) R.Nielsen, C.J.O’Kelly \& E & Entocladia viridis Reinke \\
\hline \multicolumn{3}{|l|}{ OCHROPHYTA-Phaeophyceae } \\
\hline Adenocystis utricularis & Saint-Vincent) Skottsberg & Adenocystis utricularis (Bory) Sk \\
\hline Desmarestia confervoides & Saint-Vincent) M.E.Ramírez \& A.F.Peters & Desmarestias willi Reinsch \\
\hline Durvillaea a & (Chamisso) Hariot & Durvillea sp. \\
\hline Geminocarpus geminatus & (J.D.Hooker \& Harvey) Skottsberg & Geminocarpus geminatus (Hook. F. \& Harv.) Skottsb. \\
\hline Macrocys & (Linnaeus) C.Agardh & Macrocystis pyrifera (L.) \\
\hline PHYTA & & - \\
\hline tia plicata & Fries & Ahnfeltia plicata (Huds.) Fries, $\mathrm{J}$ \\
\hline Ballia & (C.As & Ballia callitricha (C. Ag.) Mont. \\
\hline yllis tenera & J.Agardh & Callophyllis tenera J. Ag. \\
\hline Callophyllis variegata & Saint-Vincent) Kützing & yllis variegata (Bory) L. Agardh \\
\hline Ceran & Kütz & Ceramium involutum Kütz. \\
\hline Cladodonta lyallii & oker \& Harvey) Skottsberg & Cladodonta lyallii (Hook. F. \& Harv.) Skottsb. \\
\hline Colacodasya inconspicua & Schmitz & Colacodasya inconspicus (Reinsc \\
\hline Dasyptilon ptilota & ker \& Harvey) Athanasiadis & Antithamnion ptilota (HooK; f. \& Harv.) De Toni \\
\hline Heterosiphonia berkeleyi & Monta & Heterosiphonia berleleyi Mont. \\
\hline Hymenena laciniata & ker \& Harvey) Kylin & F. \& Harv.) Kylin \\
\hline Kallymenia lacinifolia & Levrir & Kallimenia lacinifolia $\mathrm{r}$ \\
\hline Lophurella hookeriana & (J.Agardl & Lophurella hookerriana (J. Ag.) Fa \\
\hline Mazzaella laminarioides & e Saint-Vincent) Fredericq & Iridaea boryana (Setch. \& Gardn) $\subseteq$ \\
\hline Myriogramme kerguelensis & Levring & Myriogramme kerguelensis \\
\hline Nothogenia fastigiata & it-Vincent) P.G.Parkinson & Chaetangium fastigatum (Bory) J. Ag. \\
\hline Palmaria decipiens & D & Leptosarca alcicornis Skottsb. Kylin \&Skottsberg \\
\hline Paraglossum epiglossum & (J.Aga & Delesseria epiglossum J. Ag. \\
\hline Paraglossum larsenii & g) S.-M.Lin, Fredericq \& Hommersand & Pseudolaingia larseneii (Skottsb.) Levr. Nov. Comb \\
\hline & er \& Harvey) Levring & $\begin{array}{l}\text { Myriogramme fuscorubra (Hook. F. \& Harv.) Levr. Nov. } \\
\text { Comb. }\end{array}$ \\
\hline Plocamium secundatum & (Kützi & Plocamium secundatum Kütz, Kylin \& Skottsberg \\
\hline Plumariopsis eatonii & (Dickie) De Toni & Plumariopsis eatoni (Dickie) De Toni \\
\hline Polysiphonia anisogona & J.D.Hooker \& Harvey & Polysiphonia anisogona Hook. F. \& Harv. \\
\hline Polysiphonia urbanoides & & Polysiphonia urbanoides n.sp. \\
\hline Ptilonia magellanica & (Montagne) J.Agardh & Ptilonia magellanica (Mont.) J. Ag. \\
\hline Schizoseris condensata & (Reinsch) R.W.Ricker & Schizoseris laciniata (Kütz.) Kylir \\
\hline Carlskottsbergia antarctic & (J.D.Hooker \& Harvey) A & Lithothamnion antarcticum (Hook. f. \& Harv.) Heydr. \\
\hline
\end{tabular}


APPENDIX 10. - Zinova (1958, in blue) reported on marine macroalgae collected during the 1st Soviet Antarctic Expedition (1956-57). She completed her list in 1963 with "Delesseriaceae". A list of algae sampled in the Hopeful Bay was also published in 1973.

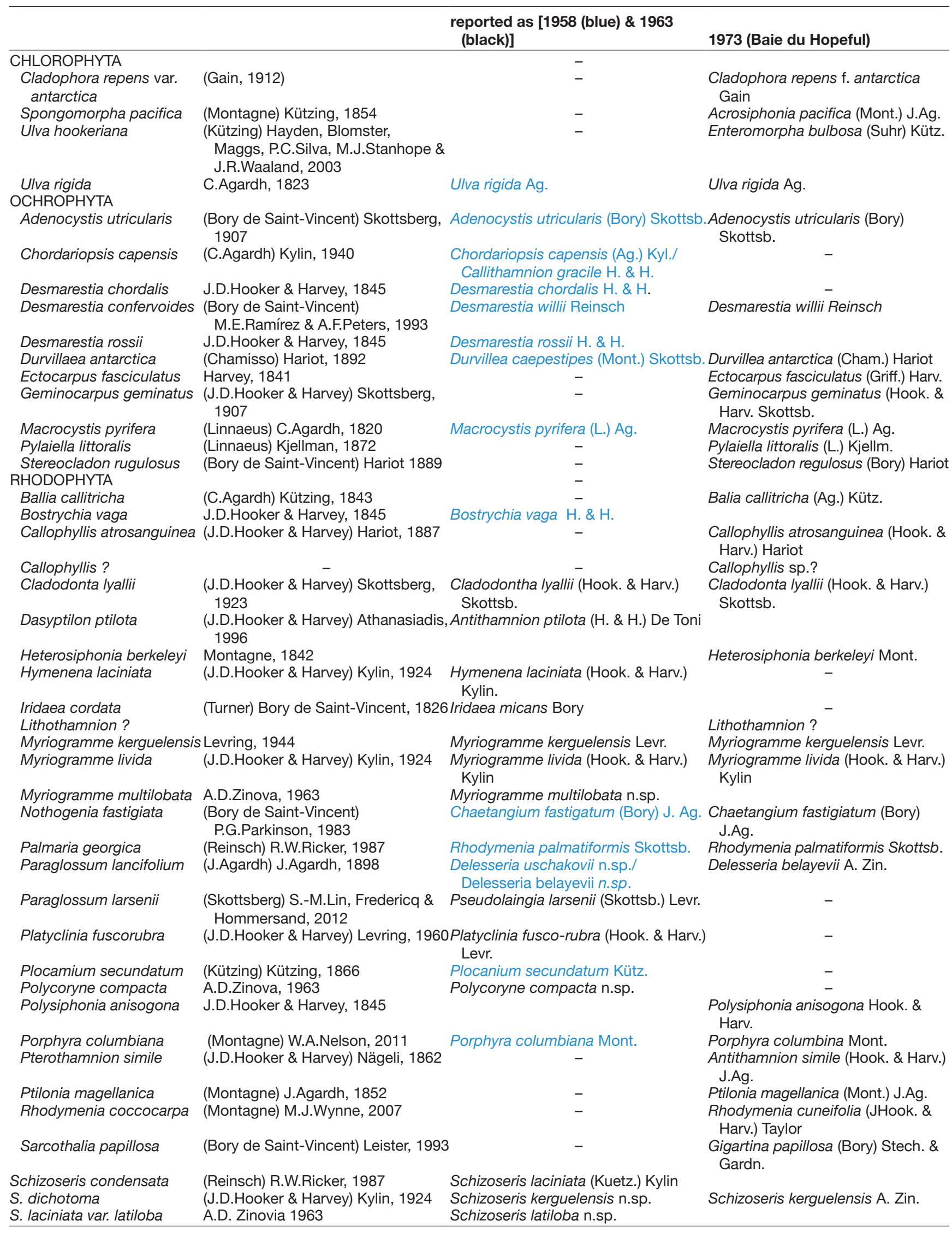


APPENDIX 11. - Papenfuss (1964a) listed 138 taxa of macroalgae in his catalogue, the most recent published synthesis on the Kerguelen Islands.

\begin{tabular}{|c|c|c|}
\hline \multicolumn{2}{|l|}{ accepted name } & reported as \\
\hline \multicolumn{3}{|l|}{ CHLOROPHYTA } \\
\hline Acrosiphonia arcta & (Dillwyn) Gain & Spongomorpha arcta (Dillwyn) Kützing \\
\hline Bryopsis plumosa & (Hudson) C.Agardh & Bryopsis plumosa (Hudson) C.Agardh \\
\hline Chaetomorpha kerguelensis & Levring & Chaetomorpha kerguelensis Levring \\
\hline Cladophora flexuosa & (O.F.Müller) Kützing & Cladophora flexuosa auct. \\
\hline Cladophora incompta & (J.D.Hooker \& Harvey) J.D.Hooker \& Harvey & $\begin{array}{l}\text { Cladophora incompta (J.D.Hooker \& Harvey) J.D.Hooker \& } \\
\text { Harvey }\end{array}$ \\
\hline Cladophora rupestris & (Linnaeus) Kützing & Cladophora rupestris (Linneaus) Kützing \\
\hline Cladophora subsimplex & Kützing & Cladophora subsimplex Kützing \\
\hline Codium adhaerens & C.Agardh & Codium adhaerens C.Agardh \\
\hline Codium decorticatum & (Woodward) M.A.Howe & Codium decorticatum (Woodward) Howe \\
\hline Codium effusum & (Rafinesque) Delle Chiaje & Codium difforme Kützing \\
\hline Codium fragile & (Suringar) Hariot & Codium fragile (Suringar) Hariot \\
\hline Codium galeatum & J.Agardh & Codium galeatum J. Agardh \\
\hline Codium tomentosum & Stackhouse & Codium tomentosum Stackhouse \\
\hline Monostroma grevillei & (Thuret) Wittrock & Monostroma grevellei (Thuret) Wittrock \\
\hline Monostroma hariotii & Gain & Monostroma hariotii Gain \\
\hline Prasiola crispa & (Lightfoot) Kützing & Prasolia crispa subsp. antarctica (Kützing) \\
\hline Prasiola cristata & (J.D.Hooker \& Harvey) J.Agardh & Prasolia cristata (J.D.Hooker \& Harvey) J.Agardh \\
\hline Prasiola filiformis & Reinsch & Prasiola filiformis Reinsch \\
\hline Rhizoclonium ambiguum & (J.D.Hooker \& Harvey) Kützing & Rhizoclinum ambiguum (J.D.Hooker \& Harvey) Kützing \\
\hline Rhizoclonium riparium & (Roth) Harvey & Rhizoclinum riparium (Roth) Harvey \\
\hline Spongomorpha aeruginosa & (Linnaeus) Hoek & Chlorochytrium inclusum Kjellman \\
\hline Spongomorpha pacifica & (Montagne) Kützing & Spongomorpha pacifica (Montagne) Kützing \\
\hline Ulva compressa & Linneaus & Enteromorpha compressa Linneaus) Greville \\
\hline Ulva hookeriana & $\begin{array}{l}\text { (Kützing) Hayden, Blomster, Maggs, P.C.Silva, } \\
\text { M.J.Stanhope \& J.R.Waaland }\end{array}$ & Enteromorpha bulbosa (Suhr) Montagne \\
\hline Ulva intestinalis & Linneaus & Enteromorpha intestin \\
\hline Uncertain status & - & Ulva lactuca auct. \\
\hline Uncertain status & - & Ulva lactuca var. latissim \\
\hline Ulva rigida & C.Agardh & Ulva rigida (C.Agardh) \\
\hline Ulvella viridis & (Reinke) R.Nielsen, C.J.O’Kelly \& B.Wysor & Entocladia viridis Reinke \\
\hline Urospora penicilliformis & (Roth) Areschoug & Codiolum gregarum Braun \\
\hline & - & penicilliformis (Roth) J.E.Aresc \\
\hline \multicolumn{2}{|l|}{ OCHROPHYTA-Phaeophyceae } & - \\
\hline Adenocystis utricularis & (Bory de Saint-Vincent) Skottsberg & Adenocy \\
\hline Caepidium antarcticum & J.Agardh & Caepidium antarcti \\
\hline Chordariopsis capensis & (C.Agardh) Kylin & Chordariopsis capensis (C.Agardh) Kylin \\
\hline Colpomenia sinuosa & (Mertens ex Roth) Derbès \& Solier & Colpomenia sinuosa (Roth) Derbes \& Solier \\
\hline Desmarestia chordalis & J.D.Hooker \& Harvey & Desmarestia chordalis J.D.Hooker \& Harvey \\
\hline Desmarestia confervoides & (Bory de Saint-Vincent) M.E.Ramírez \& A.F.Peters & Desmarestia willii Reinsch \\
\hline Desmarestia menziesii & J.Agardh & Desmarestia menziesii J.Agardh \\
\hline Desmarestia rossii & J.D.Hooker \& Harvey & Desmarestia rossii J.D.Hooker \& Harvey \\
\hline Durvillaea antarctica & (Chamisso) Hariot & Durvillea \\
\hline- & - & Durvillea caepaestipes (Montagne) Chapman \& Aiken \\
\hline Ectocarpus constanciae & Hariot & Ectocarpus constanciae Hariot \\
\hline Elachista flaccida & (Dillwyn) Fries & Elachista flaccida (Dillwyn) Fries \\
\hline Geminocarpus geminatus & (J.D.Hooker \& Harvey) Skottsberg & Geminocarpus geminatus (J.D. Hooker \& Harvey) Skottsberg \\
\hline Halopteris corymbosa & (Dickie) Draisma, Prud'homme \& H.Kawai & Alethocladus corymbosus (Dickie) Sauvageau \\
\hline Lessonia flavicans & Bory de Saint-Vincent & Lessonia fuscescens Bory \\
\hline Macrocystis pyrifera & (Linnaeus) C.Agardh & Macrocystis pyrifera (Linneaus) C. Agardh \\
\hline Petalonia fascia & (O.F.Müller) Kuntze & Petalonia fascia (O.F. Müller) O. Küntze \\
\hline Pylaiella littoralis & (Linnaeus) Kjellman & Pylaiella littoralis (Linnaeus) Kjellman \\
\hline Scytosiphon lomentaria & (Lyngbye) Link & Scytosiphon lomentaria (Lyngbye) Endlicher \\
\hline Scytothamnus fasciculatus & (J.D.Hooker \& Harvey) A.D.Cotton & Scytothamnus fasciculatus (J.D. Hooker \& Harvey) Cotton \\
\hline Sphacelaria affinis & Dickie & Sphacelaria affinis Dickie \\
\hline Utriculidium durvillei & Skottsberg & Utriculidium durvillei (Bory) Skot \\
\hline RHODOPHYTA & & - \\
\hline Acanthococcus antarcticus & J.D.Hooker \& Harvey, & Acanthococcus antarcticus J.D. Hooker \& Harvey \\
\hline Ahnfeltia plicata & (Hudson) E.M.Fries & Ahnfeltia plicata (Hudson) E.M. Fries \\
\hline Anisocladella serratodentata & (Skottsberg) Skottsberg & Erythroglossum bipinnatifidum (Montagne) J.Agardh \\
\hline Ballia callitricha & (C.Agardh) Kützing & Ballia callitricha (C.Agardh) Kützing \\
\hline Bostrychia vaga & J.D.Hooker \& Harvey & Bostrychia vaga J.D.Hooker \& Harvey \\
\hline Callophyllis angustifrons & (Harvey) G.R.South \& N.M.Adams & Callophyllis angustifrons J.D.Hooker \& Harvey \\
\hline Callophyllis atrosanguinea & (J.D.Hooker \& Harvey) Hariot & Callophyllis atrosnaguinea (J.D. hooker \& Harvey) Hariot \\
\hline Callophyllis fastigiata & (J.Agardh) J.Agardh & Callophyllis factigiata (J.Agardh) J.Agardh \\
\hline Callophyllis tenera & J.Agardh & Callophyllis tenera J.Agardh \\
\hline Callophyllis variegata & (Bory de Saint-Vincent) Kützing & Callophyllis variegata (Bory) Kützing \\
\hline Carlskottsbergia antarctica & (J.D.Hooker \& Harvey) Athanasiadis & Lithothamnium antarcticum (J.D.Hooker \& Harvey) Foslie \\
\hline Catenella fusiformis & (J.Agardh) Skottsberg & Catanella fusiformis (J.Agardh) Skottsberg \\
\hline Ceramium diaphanum & (Lightfoot) Roth & Ceramium diaphanum (Lightfoot) Roth \\
\hline
\end{tabular}


APPENDIX 11. - Continuation

\begin{tabular}{|c|c|c|}
\hline \multicolumn{2}{|l|}{ accepted name } & \multirow{2}{*}{$\begin{array}{l}\text { reported as } \\
\text { Ceramium involutum Kützing }\end{array}$} \\
\hline Ceramium involutum & Kützing & \\
\hline Ceramium virgatum & Roth, & Ceramium rubrum (Hudson) C.Agardh \\
\hline Cladodonta Iyallii & (J.D.Hooker \& Harvey) Skottsberg & Cladodonta Iyallii (J.D.Hooker \& Harvey) Skottsberg \\
\hline Clathromorphum obtectulum & (Foslie) Adey & Lithothamnium obtectulum (Foslie) Foslie \\
\hline Colacodasya inconspicua & (Reinsch) F.Schmitz & Colacodasya inconspicua (Reinsch) Schmitz \\
\hline Colacopsis velutina & (M.T.Martin \& M.A.Pocock) R.E.Norris & Melanocolax vetulina Martin \& Pocock \\
\hline Dasyptilon ptilota & (J.D.Hooker \& Harvey) Athanasiadis & Antithamnion ptilota (J.D.Hooker \& Harvey) Gibson \\
\hline Delisea pulchra & (Greville) Montagne & Delisea pulchra (Greville) Montagne \\
\hline Gracilaria pulvinata & Skottsberg & Gracilaria pulvinata Skottsberg \\
\hline Griffithsia antarctica & J.D.Hooker \& Harvey & Griffithsia antarctica J.D.Hooker \& Harvey \\
\hline Gymnogongrus turquetii & Hariot & Phyllophora appendiculata Skottsberg \\
\hline Haraldiophyllum crispatum & $\begin{array}{l}\text { (J.D.Hooker \& Harvey) S.M.Lin, Hommersand \& } \\
\text { W.A.Nelson }\end{array}$ & Myriogramme crispata (J.D.Hooker \& Harvey) Kylin \\
\hline Heterosiphonia berkeleyi & Montagne & Heterosiphonia berkeleyi Montagne \\
\hline - & - & Heterosiphonia merenia Falkenberg \\
\hline Hildenbrandia kerguelensis & (Askenasy) Y.M.Chamberlain & Hildenbranchia kerguelensis (Askenasy) Chamberlain \\
\hline Hildenbrandia lecannellieri & Hariot & Hildenbranchia lecannellieri Hariot \\
\hline Hymenena laciniata & (J.D.Hooker \& Harvey) Kylin & Hymenena laciniata (J.D.Hooker \& Harvey) Kylin \\
\hline Iridaea cordata & (Turner) Bory de Saint-Vincent & Iridaea obovata Kützing \\
\hline Iridaea undulosa & Bory de Saint-Vincent & Iridaea undolosa Bory \\
\hline Kallymenia lacinifolia & Levring & Kallymenia lacinifolia Levring \\
\hline Lithothamnion kerguelenum & (Dickie) Foslie & Lithothamnium kergelenum (Dickie) Foslie \\
\hline Lophurella hookeriana & (J.Agardh) Falkenberg & Lophurella hookeriana (J.Agardh) Falkenberg \\
\hline Lophurella patula & (J.D.Hooker \& Harvey) De Toni & Lophurella patula (J.D.Hooker \& Harvey) De Toni \\
\hline Mazzaella capensis & (J.Agardh) Fredericq & Iridaea capensis J. Agardh \\
\hline Mazzaella laminarioides & (Bory de Saint-Vincent) Fredericq & Iridaea boryana (Setchell \& Gardner) Skottsberg \\
\hline Myriogramme kerguelensis & Levring & Myrogramme kerguelensis Levring \\
\hline Myriogramme livida & (J.D.Hooker \& Harvey) Kylin & Myriogramme livida (J.D.Hooker \& Harvey) Kylin \\
\hline Myriogramme multilobata & A.D.Zinova & Myriogramme multilobata A. Zinova \\
\hline Myriogramme smithii & (J.D.Hooker \& Harvey) Kylin & Myriogramme smithii (J.D.Hooker \& Harvey) Kylin \\
\hline Nothogenia fastigiata & (Bory de Saint-Vincent) P.G.Parkinson & Chaetangium fastigiatum (Bory) J.Agardh \\
\hline Palmaria decipiens & (Reinsch) R.W.Ricker & Leptosomia alcicornis (Skottsberg) Kylin \\
\hline Palmaria georgica & (Reinsch) R.W.Ricker & Rhodymenia palmatiformis Skottsberg \\
\hline Paraglossum crassinervium & (Montagne) S.-M.Lin, Fredericq \& Hommersand & Delesseria crassinervia Montagne \\
\hline Paraglossum epiglossum & (J.Agardh) J.Agardh & Delesseria epiglossum J.Agardh \\
\hline Paraglossum lancifolium & (J.Agardh) J.Agardh & Delesseria belayevii A. Zinova \\
\hline Paraglossum larsenii & (Skottsberg) S.-M.Lin, Fredericg \& Hommersand & dPseudolaingia larsenii (Skottsberg) Levring \\
\hline Phycodrys quercifolia & (Bory de Saint-Vincent) Skottsberg & Phycodrys quercifolia (Bory) Skottsberg \\
\hline Phymatolithon lenormandii & (Areschoug) W.H.Adey & Lithothamnium lenormandii (J.E.Areschoug) Foslie \\
\hline Platyclinia fuscorubra & (J.D.Hooker \& Harvey) Levring & Platyclinia fuscorubra (J.D.Hooker \& Harvey) Levring \\
\hline Plocamium cartilagineum & (Linnaeus) P.S.Dixon & Plocamium coccineum (Hudson) Lyngbye \\
\hline Plocamium hookeri & Harvey & Plocamium hookeri Harvey \\
\hline Plocamium secundatum & (Kützing) Kützing & Plocamium secundatum (Kützing) Kützing \\
\hline Plumariopsis eatonii & (Dickie) De Toni & Plumariopsis eatoni (Dickie) De Toni \\
\hline Polycoryne compacta & A.D.Zinova & Polycoryne compacta A. Zinova \\
\hline Polysiphonia abscissa & J.D.Hooker \& Harvey & Polysiphonia abscissa (J.D.Hooker \& Harvey) \\
\hline Polysiphonia anisogona & J.D. Hooker \& Harvey & Polysiphonia anisogona J.D. Hooker \& Harvey \\
\hline Polysiphonia urbanoides & Levring & Polysiphonia urbanoides Levring \\
\hline Porphyra capensis & Kützing & Porphyra capensis Kützing \\
\hline Pseudophycodrys phylloph & a(J.Agardh) Skottsberg & Pseudophycodrys phyllophora (J.Agardh) Skottsberg \\
\hline Pterothamnion simile & (J.D.Hooker \& Harvey) Nägeli & Antithamnion simile (J.D.Hooker \& Harvey) J.Agardh \\
\hline Ptilonia magellanica & (Montagne) J.Agardh & Ptilonia magellanica (Montagne) J.Agardh \\
\hline Rhodochorton purpureum & (Lightfoot) Rosenvinge & Rhodochorton purpureum (Lightfoot) Rosenvinge \\
\hline Rhodoglossum gigartinoides & (Sonder) Edyvane \& Womersley & Iridaea latissima (J.D.Hooker \& Harvey) Grunow \\
\hline Rhodophyllis reptans & (Suhr) Papenfuss & Rhodophyllis reptans (Suhr) Papenfuss \\
\hline Rhodymenia capensis & J.Agardh & Epymenia capensis (J.Agardh) Papenfuss \\
\hline Rhodymenia coccocarpa & (Montagne) M.J.Wynne & Rhodymenia cuneifolia (J.D.Hooker \& Harvey) Taylor \\
\hline Rhodymenia dichotoma & J.D. Hooker \& Harvey & Rhodymenia dichotoma J.D. Hooker \& Harvey \\
\hline Rhodymenia obtusa & (Greville) Womersley & Epymenia obtusa (Greville) Kützing \\
\hline Rhodymenia & J.D.Hooker \& Harvey & Epymenia variolosa (J.D.Hooker \& Harvey) Kützing \\
\hline Sarcodia & Sonder & Sarcodia palmata Sonder? \\
\hline Sarcothalia & (Bory de Saint-Vincent) Leister & Gigartina papillosa (Bory) Setchell \& Gardner \\
\hline Schizoseris & (Reinsch) R.W.Ricker & Schizoseris laciniata (Kützing) Kylin \\
\hline Schizoseris & (J.D.Hooker \& Harvey) Kylin & Myriogramme multinervis (J.D.Hooker \& Harvey) Kylin \\
\hline _ & - & Schizoseris dichotoma (J.D.Hooher \& Harvey) Kylin \\
\hline - & - & Schizoseris kerguelensis A.Zinova \\
\hline & & Schizoseris laciniata f. latiloba A.Zinova \\
\hline Schizoseris & (Suhr) M.J.Wynne & Schizoseris davissi (J.D.Hooker \& Harvey) Kylin \\
\hline Spongites & (Foslie) D.Penrose \& Woelkerling & Pseudolithophyllum consociatum (Foslie) Lemoine \\
\hline Synarthrophyton & (Foslie) M.L.Mendoza & Lithothamnium neglectum (Foslie) Foslie \\
\hline
\end{tabular}


APPENDIX 12. - In 1996, Delépine made the last compilation of macroalgae from the French Austral Islands to be included in an application document to create a Nature Reserve of the French sub-Antarctic Islands (personal communication, JPF, Jouventin et al. 1996).

\begin{tabular}{|c|c|c|}
\hline \multicolumn{2}{|l|}{ accepted name } & reported as \\
\hline CHLOROPHYTA & & - \\
\hline Acrosiphonia arcta & (Dillwyn) Kützing & Spongiomorpha arcta (Dillw.) \\
\hline Bryopsis plumosa & (Hudson) C.Agardh & Bryopsis plumosa Agardh \\
\hline Chaetomorpha kerguelensis & Levring & Chaetomorpha kerguelensis Levring \\
\hline Cladophora flexuosa & (O.F.Müller) Kützing & Cladophora flexuosa H. \& H. \\
\hline Cladophora incompta & (J.D.Hooker \& Harvey) J.D.Hooker \& Harvey & Cladophora incompta H. \& H. \\
\hline Cladophora rupestris & (Linnaeus) Kützing & Cladophora rupestris (L.) \\
\hline Cladophora subsimplex & Kützing & Cladophora subsimplex Kütz. \\
\hline Codium adhaerens & C.Agardh & Codium adhaerens Agardh \\
\hline Codium decorticatum & (Woodward) M.A.Howe & Codium decorticum (Woodward) \\
\hline Codium effusum & (Rafinesque) Delle Chiaje & Codium difforme Kütz. \\
\hline Codium fragile & (Suringar) Hariot & Codium fragile (Suringar) \\
\hline Codium galeatum & J.Agardh & Codium galatheum Agardh \\
\hline Codium tomentosum & Stackhouse & Codium tomentosum Stackhouse \\
\hline Monostroma grevillei & (Thuret) Wittrock & Monostroma grevillei Thuret \\
\hline Monostroma hariotii & Gain & Monostroma hariotii Gain \\
\hline Prasiola crispa & (Lightfoot) Kützing & Prasiola crispa (Kütz.) \\
\hline Prasiola cristata & (J.D.Hooker \& Harvey) J.Agardh & Prasiola cristata (Hooker \& Harvey) \\
\hline Prasiola filiformis & Reinsch & Prasiola filiformis Reinsch \\
\hline Rhizoclonium ambiguum & (J.D.Hooker \& Harvey) Kützing & Rhizoclonium ambiguum (Hooker \& Harvey) \\
\hline Rhizoclonium riparium & (Roth) Harvey & Rhizoclonium riparium (Roth) \\
\hline Spongomorpha aeruginosa & (Linnaeus) Hoek & Chlorochytrium inclusum Kjellman, 1883 \\
\hline Spongomorpha pacifica & (Montagne) Kützing & Spongiomorpha pacifica (Montagne) \\
\hline Ulothrix flacca & (Dillwyn) Thuret & Ulothrix pseudoflacca Wille \\
\hline Ulva compressa & Linneaus & Enteromorpha compressa L. \\
\hline Ulva hookeriana & $\begin{array}{l}\text { (Kützing) Hayden, Blomster, Maggs, P.C.Silva, } \\
\text { M.J.Stanhope \& J.R.Waaland }\end{array}$ & Enteromorpha bulbosa (Suhr) \\
\hline Ulva intestinalis & Linneaus & Enteromorpha intestinalis L. \\
\hline Ulva lactuca & Linneaus & Ulva lactuca (L.) \\
\hline Uncertain status & - & Ulva latissima auct. \\
\hline Ulva rigida & C.Agardh & Ulva rigida (Agardh) \\
\hline Ulvella viridis & (Reinke) R.Nielsen, C.J.O’Kelly \& B.Wysor & Entocladia viridis Reinke \\
\hline Urospora penicilliformis & (Roth) Areschoug & Codiolum gregarium A. Braun 1855 \\
\hline \multicolumn{3}{|c|}{ OCHROPHYTA-Phaeophyceae } \\
\hline Adenocystis utricularis & (Bory de Saint-Vincent) Skottsberg & Adenocystis utricularis (Bory) \\
\hline Caepidium antarcticum & J.Agardh & Caepidium antarcticum Agardh \\
\hline Chordariopsis capensis & (C.Agardh) Kylin & Chordariopsis capensis (Agardh) \\
\hline Cladothele decaisnei & J.D.Hooker \& Harvey & Cladothele decaisnei Hooker \& Harvey \\
\hline Colpomenia sinuosa & (Mertens ex Roth) Derbès \& Solier & Colpomenia sinuosa (Roth) \\
\hline Desmarestia chordalis & J.D.Hooker \& Harvey & Desmarestia chordalis Hooker \& Harvey $=$ D. rossii \\
\hline Desmarestia confervoides & (Bory de Saint-Vincent) M.E.Ramírez \& A.F.Peters & Desmarestia confervoides \\
\hline Desmarestia ligulata & (Stackhouse) J.V.Lamouroux & Desmarestia ligulata (Lightf.) \\
\hline Desmarestia menziesii & J.Agard & Desmarestia menziesii Ăgardh \\
\hline Durvillaea antarctica & (Chamisso) Hariot & $\begin{array}{l}\text { Durvillea antarctica (Chamisso in Choris) }=D \text {. } \\
\text { caepestipes }\end{array}$ \\
\hline Ectocarpus constanciae & Hariot & Ectocarpus constanciae Hariot \\
\hline Elachista flaccida & (Dillwyn) Fries & Elachista flaccida (Dillw.) \\
\hline Geminocarpus geminatus & (J.D.Hooker \& Harvey) Skottsberg & Geminocarpus geminatus (Hooker \& Harvey) \\
\hline Halopteris corymbosa & (Dickie) Draisma, Prud'homme \& H.Kawai & Alethocladus corymbosum (Dickie) \\
\hline Lessonia flavicans & Bory de Saint-Vincent & Lessonia flavicans Bory \\
\hline 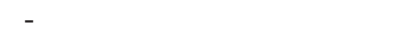 & - & Lessonia fuscescens Bory \\
\hline Macrocystis pyrifera & (Linnaeus) C.Agardh & Macrocystis pyrifera (L.) \\
\hline Petalonia fascia & (O.F.Müller) Kuntze & Petalonia fascia (Müller) \\
\hline Pylaiella littoralis & (Linnaeus) Kjellman & Pylaiella littoralis (L.) \\
\hline Scytosiphon lomentaria & (Lyngbye) Link & Scytosiphon lomentaria Lyngbye \\
\hline Scytothamnus fasciculatus & (J.D.Hooker \& Harvey) A.D.Cotton & Scytothamnus fasciculotus Hooker \& Harvey \\
\hline Sphacelaria affinis & Dickie & Sphacelaria affinis Dickie \\
\hline Utriculidium durvillei & Skottsberg & Utriculidium durvillei (Bory) \\
\hline RHODOPHYTA & & - \\
\hline Acanthococcus antarcticus & J.D.Hooker \& Harvey & Acanthococcus antarcticus Hooker \& Harvey \\
\hline Ahnfeltia plicata & (Hudson) E.M.Fries & Ahnfeltia plicata (Hudson) \\
\hline Anisocladella serratodentata & (Skottsberg) Skottsberg & Erythroglossum bipinnatifidum (Montagne) \\
\hline Ballia callitricha & (C.Agardh) Kützing & Ballia callitricha (Agardh) \\
\hline Bostrychia vaga & J.D.Hooker \& Harvey & Bostrychia vaga (Hooker \& Harvey) \\
\hline Callocolax neglectus & F.Schmitz ex Batters & Callocolax neglectus Schmitz \\
\hline Callophyllis angustifrons & (Harvey) G.R.South \& N.M.Adams & Rhodophyllis angustifrons Harvey \\
\hline Callophyllis atrosanguinea & (J.D.Hooker \& Harvey) Hariot & Callophyllis atrosanguinea (Hooker \& Harvey) \\
\hline Callophyllis fastigiata & (J.Agardh) J.Agardh & Callophyllis fastigiata (Agardh) \\
\hline Callophyllis tenera & J.Agardh & Callophyllis tenera Agardh \\
\hline
\end{tabular}




\begin{tabular}{|c|c|c|}
\hline accepted name & & reported as \\
\hline Callophyllis variegata & (Bory de Saint-Vincent) Kützing & Callophyllis variegata (Bory) \\
\hline Carlskottsbergia antarctica & (J.D.Hooker \& Harvey) Athanasiadis & Lithothamnion antarcticum (Hooker \& Harvey) \\
\hline Ceramium diaphanum & (Lightfoot) Roth & Ceramium diaphanum (Lightf.) \\
\hline Ceramium virgatum & Roth & Ceramium rubrum (Hudson) \\
\hline Cladodonta lyallii & (J.D.Hooker \& Harvey) Skottsberg & Cladodonta lyalli (Hooker \& Harvey) \\
\hline Clathromorphum obtectulum & (Foslie) Adey & Lithothamnion obtectulum (Foslie) \\
\hline Colacodasya inconspicua & (Reinsch) F.Schmitz & Colacodasya inconspicua (Reinsch) \\
\hline Colacopsis velutina & (M.T.Martin \& M.A.Pocock) R.E.Norris & Melanocolax velutina Martin \& Pocock \\
\hline Dasyptilon ptilota & (J.D.Hooker \& Harvey) Athanasiadis & Antithamnion ptilota (Hooker \& Harvey) \\
\hline Delisea pulchra & (Greville) Montagne & Delisea pulchra (Greville) \\
\hline Erythroglossum laciniatum & (Lightfoot) Maggs \& Hommersand & Porphyra laciniata (Lightf.) \\
\hline Gracilaria pulvinata & Skottsberg & Gracilaria pulvinata Skotts. \\
\hline Grateloupia cutleriae & Kützing & Grateloupia cutleriae Kütz. \\
\hline Griffithsia antarctica & J.D.Hooker \& Harvey & Griffithsia antarctica Hooker \& Harvey \\
\hline Gymnogongrus turquetii & Hariot & Phyllophora appendiculata Skotts. \\
\hline Haraldiophyllum crispatum & $\begin{array}{l}\text { (J.D.Hooker \& Harvey) S.M.Lin, Hommersand \& } \\
\text { W.A.Nelson }\end{array}$ & Myriogramme crispata (Hooker \& Harvey) \\
\hline Heterosiphonia berkeleyi & Montagne & Heterosiphonia berkleyi Montagne \\
\hline- & 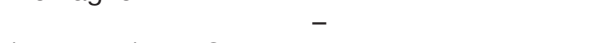 & Heterosiphonia merenia Falkenb. \\
\hline Hildenbrandia kerguelensis & (Askenasy) Y.M.Chamberlain & Hildenbranchia kerguelenensis (Askenazy) \\
\hline Hildenbrandia lecannellieri & Hariot & Hildenbranchia lecanellieri Hariot \\
\hline Hymenena laciniata & (J.D.Hooker \& Harvey) Kylin & Hymenea laciniata (Hooker \& Harvey) \\
\hline Iridaea cordata & (Turner) Bory de Saint-Vincent & Iridaea cordata Turner \\
\hline Iridaea undulosa & Bory de Saint-Vincent & Iridaea undulosa Bory \\
\hline Kallymenia lacinifolia & Levring & Kallymenia lacinifolia Levring \\
\hline Lithothamnion granuliferum & Foslie & Lithothamnion granuliferum Foslie \\
\hline Lithothamnion kerguelenum & (Dickie) Foslie & Lithothamnion kerguelenum (Dickie) \\
\hline Lophurella hookeriana & (J.Agardh) Falkenberg & Lophurella hookerriana (Agardh) \\
\hline Lophurella patula & (J.D.Hooker \& Harvey) De Toni & Lophurella patula (Hooker \& Harvey) \\
\hline Mazzaella capensis & (J.Agardh) Fredericq & Iridaea capensis Agardh \\
\hline Mazzaella laminarioides & (Bory de Saint-Vincent) Fredericq & Iridaea boryana (Setchell \& Gardner) \\
\hline - & & Iridaea laminaroides Bory \\
\hline Myriogramme kerguelensis & Levring & Myriogramme kerguelensis Levring \\
\hline Myriogramme livida & (J.D.Hooker \& Harvey) Kylin & $\begin{array}{l}\text { Myriogramme livida (Hooker \& Harvey) / M. crozieri } \\
\text { (Hooker \& Harvey) }\end{array}$ \\
\hline Myriogramme multilobata & A.D.Zi & Myriogramme multilobata Zinova \\
\hline Myriogramme smithii & ker \& Harvey) Kylin & Myriogramme smithii (Hooker \& Harvey) \\
\hline Nothogenia fastigiata & (Bory de Saint-Vincent) P.G.Parkinson & Chaetangium fastigiatum (Bory) \\
\hline Palmaria decipiens & (Reinsch) R.W.Ricker & Leptosomia simplex (Gepp \& Gepp) \\
\hline Palmaria georgica & (Reinsch) R.W.Ricker & Rhodymenia palmatiformis Skotts. \\
\hline Paraglossum crassinervium & (Montagne) S.-M.Lin, Fredericq \& Hommersand & Delesseria crassinervia Montagne \\
\hline Paraglossum crozetii & (Levring) S.-M.Lin \& Hommersand & Delesseria crozeti Levring \\
\hline Paraglossum epiglossum & (J.Agardh) J.Agardh & Delesseria epiglossum Agardh \\
\hline Paraglossum larsenii & (Skottsberg) S.-M.Lin, Fredericg \& Hommersand & Pseudolaingia larsenii (Skotts.) \\
\hline Phycodrys quercifolia & (Bory de Saint-Vincent) Skottsberg & Phycodrys quercifolia (Bory) \\
\hline Phymatolithon lenormandii & (Areschoug) W.H.Adey & Lithothamnion lenormandii (Areschoug) \\
\hline Platyclinia fuegiensis & Skottsberg & Platyclinia fuegiensis Skotts. \\
\hline Platyclinia fuscorubra & (J.D.Hooker \& Harvey) Levring & Platyclinia fuscorubra (Hooker \& Harvey) \\
\hline Plocamium cartilagineum & (Linnaeus) P.S.Dixon & Plocamium cartilagineum $(\mathrm{L})=$.$P . coccineum Lyngbye$ \\
\hline Plocamium cruciferum & Harvey & Plocamium cruciferum Harvey \\
\hline Plocamium hookeri & Harvey & Plocamium hookeri Harvey \\
\hline Plocamium secundatum & (Kützing) Kützing & Plocanium secundatum (Kütz.) \\
\hline Plumariopsis eatonii & (Dickie) De Toni & Plumaropsis eatoni (Dickie) \\
\hline Polycoryne compacta & A.D.Zinova & Polycoryne compacta Zinova \\
\hline Polysiphonia abscissa & J.D.Hooker \& Harvey & Polysiphonia abscissa Hooker \& Harvey \\
\hline Polysiphonia anisogona & J.D.Hooker \& Harvey & Polysiphonia anisogona Hooker \& Harvey \\
\hline Polysiphonia atricapilla & J.Agardh & Polycsiphonia atricapilla Agardh \\
\hline Polysiphonia flabelliformis & J.D.Hooker \& Harvey & Polysiphonia flabelliformis Hooker \& Harvey \\
\hline Polysiphonia urbanoides & Levring & Polysiphonia urbanoides Levring \\
\hline Porphyra capensis & Kützing & Porphyra capensis Kütz. \\
\hline Pseudophycodrys phyllophora & (J.Agardh) Skottsberg & Pseudophycodrys phyllophora (Agardh) \\
\hline Pterothamnion simile & (J.D.Hooker \& Harvey) Nägeli & Antithamnion simile (Hooker \& Harvey) \\
\hline Ptilonia magellanica & (Montagne) J.Agardh & Ptilonia magellanica (Montagne) \\
\hline Rhodochorton purpureum & (Lightfoot) Rosenvinge & Rhodochorton purpureum (Lightf.) \\
\hline Rhodoglossum gigartinoides & (Sonder) Edyvane \& Womersley & Iridaea latissima (Hooker \& Harvey) \\
\hline Rhodophyllis reptans & (Suhr) Papenfuss & Rhodophyllis reptans (Suhr) \\
\hline Rhodymenia capensis & J.Agardh & Epymenia capensis (Agardh) \\
\hline Rhodymenia coccocarpa & (Montagne) M.J.Wynne & Rhodymenia cuneifolia (J.D. Hooker \& Harvey) \\
\hline Rhodymenia dichotoma & J.D.Hooker \& Harvey & Rhodymenia dichotoma Hooker \& Harvey \\
\hline
\end{tabular}


APPENDIX 12. - Continuation.

\begin{tabular}{|c|c|c|}
\hline accepted name & & reported as \\
\hline Rhodymenia obtusa & (Greville) Womersley & Epymenia obtusa (Greville) \\
\hline Rhodymenia variolosa & J.D.Hooker \& Harvey & Epymenia variolosa (Hooker \& Harvey) \\
\hline Sarcodia palmata & Sonder, 1871 & Sarcodia palmata Sonder \\
\hline Sarcopeltis skottsbergii & $\begin{array}{l}\text { (Setchell \& N.L.Gardner) Hommersand, Hughey, } \\
\text { Leister \& Gabrielson }\end{array}$ & Gigartina skottsbergi Setchell \& Gardner \\
\hline Sarcothalia papillosa & (Bory de Saint-Vincent) Leister & Gigartina papillosa (Bory) \\
\hline Schizoseris condensata & (Reinsch) R.W.Ricker & Schizoseris laciniata (Kütz.) \& var. latiloba Zinova \\
\hline Schizoseris dichotoma & (J.D.Hooker \& Harvey) Kylin & Myriogramme multinervis (Hooker \& Harvey) \\
\hline- & - & Schizozeris dichotoma (Hooker \& Harvey) \\
\hline- & - & Schizozeris kerguelensis A.D.Zinova \\
\hline Schizoseris griffithsia & (Suhr) M.J.Wynne & Schizoseris davisii (Hooker \& Harvey) \\
\hline Spongites discoideus & (Foslie) D.Penrose \& Woelkerling & Lithophyllum subantarcticum (Foslie) \\
\hline- & - & Pseudolithophylum consociatum \\
\hline Synarthrophyton neglectum & (Foslie) M.L.Mendoza & Lithothamnion neglectum (Foslie) \\
\hline
\end{tabular}

